\title{
State-of-the-Art Review of Enzyme-Induced Calcite Precipitation (EICP) for Ground Improvement: Applications and Prospects
}

\author{
Mohamed G. Arab ${ }^{1,2, *}$, Rami Alsodi ${ }^{1,3}$, Abdullah Almajed ${ }^{4} \oplus$, Hideaki Yasuhara ${ }^{5}$, Waleed Zeiada ${ }^{1,6}$ \\ and Mohamed A. Shahin ${ }^{7}$ (D) \\ 1 Department of Civil and Environmental Engineering, College of Engineering, University of Sharjah, \\ Sharjah 27272, United Arab Emirates; U15200111@sharjah.ac.ae (R.A.); wzeiada@sharjah.ac.ae (W.Z.) \\ 2 Structural Engineering Department, Mansoura University, Al-Gomhoria Street, Mansoura 35516, Egypt \\ 3 Public Works Directorate, Street 2, Al Nasserya 61239, Sharjah 27272, United Arab Emirates \\ 4 College of Civil Engineering, King Saud University, Riyadh 11421, Saudi Arabia; alabduallah@ksu.edu.sa \\ 5 Graduate School of Science and Engineering, Ehime University, Matsuyama 790-8577, Japan; \\ yasuhara.hideaki.me@ehime-u.ac.jp \\ 6 Public Works Engineering Department, Mansoura University, Al-Gomhoria Street, Mansoura 35516, Egypt \\ 7 School of Civil and Mechanical Engineering, Curtin University, Perth, WA 6845, Australia; \\ m.shahin@curtin.edu.au \\ * Correspondence: marab@sharjah.ac.ae
}

Citation: Arab, M.G.; Alsodi, R.; Almajed, A.; Yasuhara, H.; Zeiada, W.; Shahin, M.A. State-of-the-Art Review of Enzyme-Induced Calcite Precipitation (EICP) for Ground Improvement: Applications and Prospects. Geosciences 2021, 11, 492. https://doi.org/10.3390/ geosciences11120492

Academic Editors: José

Ignacio Alvarez and

Jesus Martinez-Frias

Received: 19 October 2021

Accepted: 25 November 2021

Published: 30 November 2021

Publisher's Note: MDPI stays neutral with regard to jurisdictional claims in published maps and institutional affiliations.

Copyright: (c) 2021 by the authors. Licensee MDPI, Basel, Switzerland. This article is an open access article distributed under the terms and conditions of the Creative Commons Attribution (CC BY) license (https:// creativecommons.org/licenses/by/ $4.0 /)$.

\begin{abstract}
The global construction industry consumes huge amounts of mined materials that are considered unsustainable for earth resources. In addition, Portland cement which is a key element in concrete and most construction materials is considered one of the main contributors to worldwide $\mathrm{CO}_{2}$ emissions. On the other hand, natural cemented soil deposits are examples of sustainable structures that have survived decades of severe environmental conditions. Mimicking these natural biological systems provide an alternative to the current practices of construction materials production. Enzyme-induced carbonate precipitation (EICP) is a bio-inspired technique based on the precipitation of calcium carbonate for enhancing the geo-mechanical properties of soils. In this technique, calcium carbonate acts as a cementitious agent that binds the soil particles together at the points of contact, hence, increasing the strength and stiffness of treated soils, while relatively reducing the soil permeability and porosity. The achieved enhancements make EICP useful for applications such as ground improvement, construction materials, and erosion control over traditional binders. This paper presents a state-of-the-art review of EICP for ground improvement including the fundamental basics of EICP treatment. The paper also discusses the chemical and physical factors affecting the performance of EICP such as enzyme source, enzyme activity and solution constitutes. Moreover, the paper reviews the different methods and testing techniques used in the application of EICP for soil treatment. Furthermore, the paper compares EICP with other biomineralization techniques in terms of performance and applicability on ground improvement. Finally, the paper discusses the research gaps and existing challenges concerning the commercialization and large-scale implementation of the technology.
\end{abstract}

Keywords: bio-cementation; soil stabilization; ground improvement; bio-grouting; bio-inspired treatment; urea hydrolysis; calcium carbonate; calcite precipitation

\section{Introduction}

Recently, more sustainable and environmentally friendly solutions have been demanded to mitigate the adverse effects of pollution on the environment. Current construction and soil improvement practices are major sources of carbon dioxide emissions worldwide due to the extensive use of ordinary Portland cement (OPC). Over the last decade 
or so, extensive research has been undertaken to develop eco-friendly binders for soil improvement as alternatives to OPC [1-5]. Among all existing soil binders, bio-cementation via carbonate precipitation has shown great promise as a bio-inspired technique to enhance soil geo-mechanical properties. Bio-cementation is inspired by living organisms that use organic and inorganic compounds to build strong and rigid materials [6]. Several techniques can be used to induce bio-mediated or bio-inspired carbonate precipitation, including urea hydrolysis, microbial denitrification, and sulphate reduction $[7,8]$. However, the hydrolysis of urea is the most advanced mechanism for inducing carbonate precipitation and the most often discussed in the literature due to its relative simplicity [9-14].

Urea hydrolysis utilizing bacteria (sporosarcina pasteurii) as a source of urease enzyme for soil cementation was first discussed by Whiffin [10] and later called "microbial-induced carbonate precipitation (MICP)". Various studies have examined the potential use of MICP in addressing many challenges in granular soils, such as erosion resistance, slope stability, under-seepage of levees, and bearing capacity of shallow foundations [1,13,15-18]. However, several drawbacks of MICP have limited its field application, such as the need for multiple cycles of treatment to reach sufficient carbonate precipitation and the relatively large size of exogenous bacteria, which makes it limited to the soil in which the pore throats are bigger than bacterial size $[3,19,20]$. In addition, since bacteria are living organisms, a suitable and sensitive environment is required for bacterial growth and enzyme production including the temperature, $\mathrm{PH}$, and oxygen availability for some bacterial species [21-23].

To overcome the abovementioned problems associated with MICP, free urease enzymes derived from a plant source was first suggested by Nemati and Voordouw [9] and used as a catalyst in hydrolysis. This hydrolysis technique is usually referred to as "enzyme-induced carbonate precipitation (EICP)". Unlike MICP, the free urease enzyme used in EICP has a size of the order of $12 \mathrm{~nm}$ and is soluble in water [19], which contributes to increasing the groutability of the enzyme solution inside the soil pores. Moreover, the use of free enzymes obviates the need to provide nutrients for bacterial activity, thus, facilitating the field applicability and reducing the treatment costs [3,9]. In addition, since no living organisms exist in EICP, it is not affected by the cellular processes or metabolic rates specific to microbial organisms [24].

This paper presents a state-of-the-art review of the use of EICP for improving soil geo-mechanical and physical properties, and the associated potential geotechnical and construction applications. An extensive experimental dataset for various geotechnical properties of EICP treated sand is complied, including unconfined compressive strength (UCS), shear strength parameters, and hydraulic conductivity. Furthermore, these engineering properties of EICP-treated sands are analysed and correlated to various factors. The analysis of the complied data from the literature is expected to provide insights into the best practices and eventually help researchers to identify research gaps within the technology. This objective is achieved by underlining the factors affecting the hydrolysis via EICP, and comparison of EICP and MICP. Finally, the advantages, limitations, and future research directions for bio-cementation via EICP are presented with a focus on presenting envisioned applications for the technology.

\section{Bio-Mineralization via Enzyme Induced Carbonate Precipitation (EICP)}

\subsection{Development of EICP Technique}

Nemati and Voordouw [9] were the first to propose the use of free urease enzyme derived from a plant source as a catalyst in carbonate biomineralization for geotechnical applications. In their study, the enzymatic reaction to produce carbonate was used to reduce the soil permeability and clogging of soil pores for possible application in oil recovery. The use of enzymatic reaction to improve sand soil mechanical properties was first proposed by Yasuhara et al. $[25,26]$. In their studies, they have shown substantial improvement in soil unconfined compressive strength (UCS) after treatment of soil with multiple cycles of enzymatic solution. In 2015, Kavazanjian and Hamdan [3] were the first to introduce the term (EICP) for the biomineralization process using plant-driven urease enzyme in 
urea hydrolysis. In their study, EICP solution was injected in sand columns to improve soil mechanical properties.

Since its development, EICP has been used in several other applications such as dust suppressants for wind erosion control [27-32], mitigation of liquefaction of sand [33], bio-bricks [34], surface water erosion control [35], and concrete crack healing [36]. In the pie chart shown in Figure 1, the number of research studies conducted on the use of EICP in geotechnical, construction, and building materials are categorized based on the applications. As shown in the figure, most of the studies conducted explored the use of EICP for improving the mechanical properties of sandy soils at the laboratory scale. Few recent studies explored the use of EICP cementing solution in field applications as a grout for ground improvement [37]. Moreover, few recent studies explored the life cycle assessment (LCA) of EICP as a suppressant for wind erosion control [31] and as a grout for ground improvement [37].

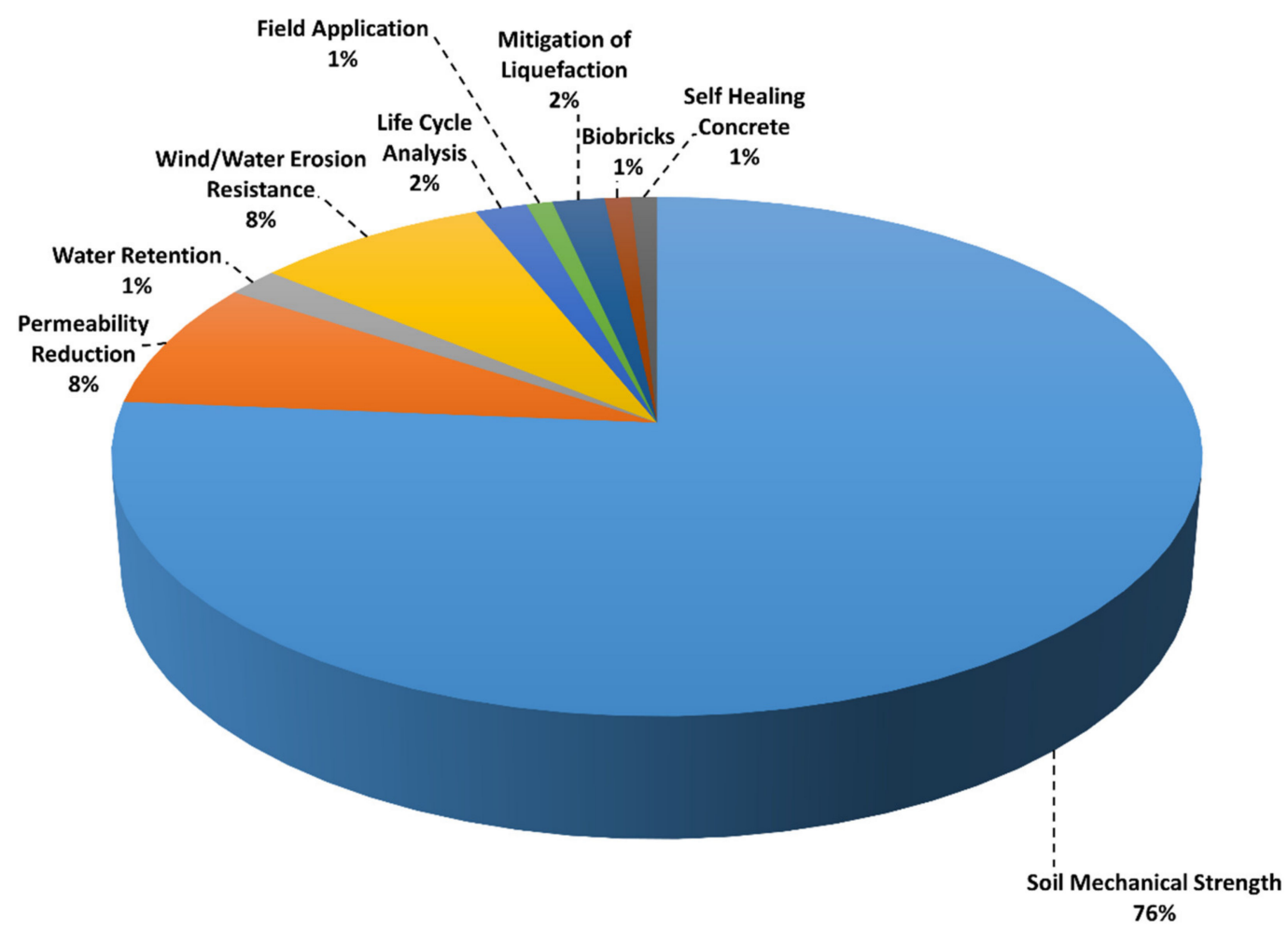

Figure 1. Pie chart showing the number of research works utilizing EICP in geotechnical engineering applications in addition to construction and building materials applications.

\subsection{EICP Overview}

In general, the process of urease-aided carbonate mineralization (regardless of the enzyme source used) is derived by the urease catalysing the hydrolysis of urea. This reaction produces ammonia $\left(\mathrm{NH}_{3}\right)$ and carbamate which are unstable and subsequently degrade to produce a second ammonia molecule and carbonic acid $\left(\mathrm{H}_{2} \mathrm{CO}_{3}\right)$, as shown in Equation (1) [38].

$$
\mathrm{H}_{2} \mathrm{~N}-\mathrm{CO}-\mathrm{NH}_{2}+2 \mathrm{H}_{2} \mathrm{O} \stackrel{\text { urease }}{\longrightarrow} \mathrm{H}_{2} \mathrm{CO}_{3}+2 \mathrm{NH}_{3}
$$

These products in the presence of water give bicarbonate, ammonium, and hydroxide ions, respectively, as shown in Equations (2) and (3) [39]:

$$
\begin{gathered}
\mathrm{H}_{2} \mathrm{CO}_{3} \rightleftarrows \mathrm{HCO}_{3}^{-}+\mathrm{H}^{+} \\
\mathrm{NH}_{3}+\mathrm{H}_{2} \mathrm{O} \rightleftarrows \mathrm{NH}_{4}^{+}+\mathrm{OH}^{-}
\end{gathered}
$$


The production of hydroxide ions from reaction (3) results in an increase in $\mathrm{pH}$, which in turn leads to the formation of carbonate ions, as shown in Equation (4):

$$
\mathrm{HCO}_{3}^{-}+\mathrm{OH}^{-} \rightleftarrows \mathrm{CO}_{3}^{2-}+\mathrm{H}_{2} \mathrm{O}
$$

This process can be summarized in Equation (5), as shown in Figure 2.

$$
\mathrm{CO}\left(\mathrm{NH}_{2}\right)_{2(s)}+2 \mathrm{H}_{2} \mathrm{O} \stackrel{\text { urease enzyme }}{\rightarrow} 2 \mathrm{NH}_{4(a q)}^{+}+\mathrm{CO}_{3}^{2-}(a q)
$$

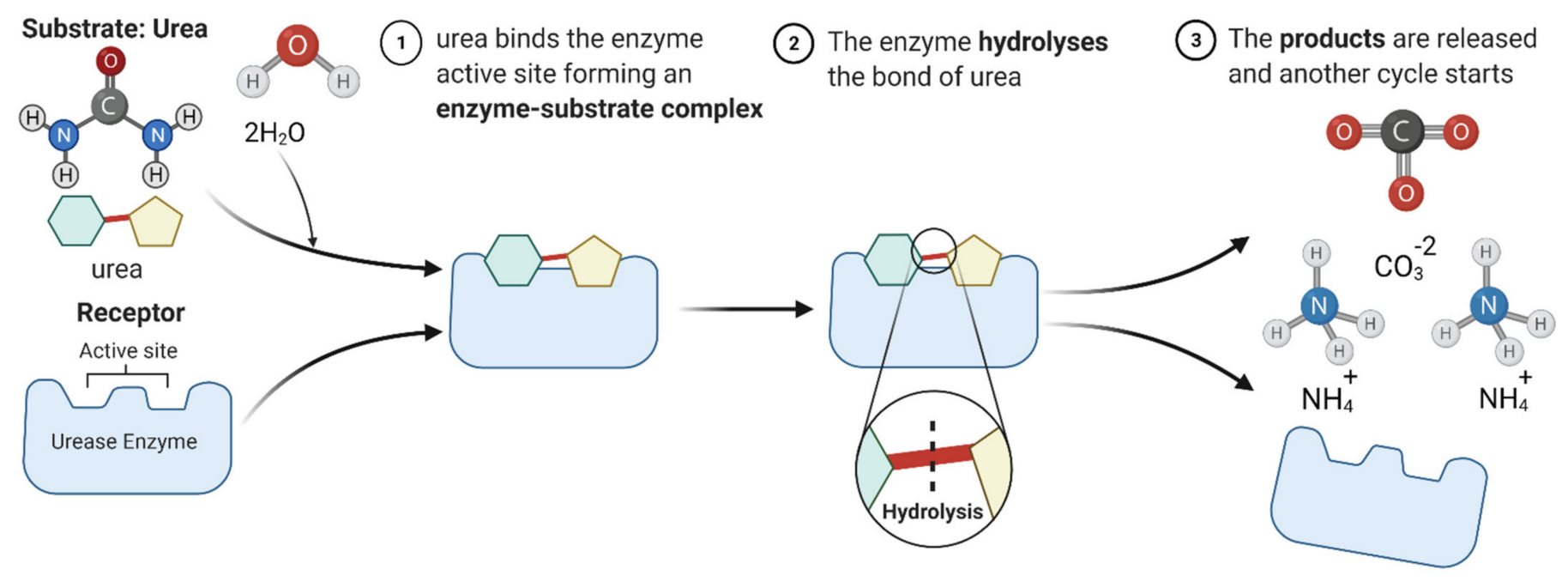

Figure 2. Schematic for hydrolysis of urea process using urease enzyme.

The increase in $\mathrm{pH}$ in the presence of dissolved $\mathrm{Ca}^{2+}$ creates favourable conditions for ions to merge, leading to calcium carbonate precipitation, as summarized by Equations (6) and (7).

$$
\begin{gathered}
\mathrm{CaCl}_{2(s)} \stackrel{\mathrm{H}_{2} \mathrm{O}}{\longleftrightarrow} \mathrm{Ca}^{2+}{ }_{(a q)}+2 \mathrm{Cl}^{-}{ }_{(a q)} \\
\mathrm{Ca}^{2+}{ }_{(a q)}+\mathrm{CO}_{3(a q)}^{2-} \stackrel{\text { precipitation }}{\leftrightarrow} \mathrm{CaCO}_{3(s)}
\end{gathered}
$$

The overall process for EICP is summarized in Figure 3; carbonate precipitation takes place by the supply of carbonate ions and the alkalinity resulting from urea hydrolysis. Active calcium carbonate crystals (precipitates) bind soil particles together as they accumulate at the soil contact points, thus, the produced cementation between the soil particles increases. However, carbonate precipitation may occur in locations other than grain contact points producing inactive crystals that do not contribute to soil cementation (Figure 3).

\section{Urease Enzyme Source}

As mentioned earlier, the EICP technique uses a free urease enzyme as a catalyst for the hydrolysis process. Urease can be extracted from either bacterial [24] or plant sources [9]; however, the extraction of urease from plant sources is the most common method for EICP applications. Several plant sources used for urease enzyme were found in the literature, including watermelon seeds, soybean, pumpkin seeds, winged bean seeds, and jack bean seeds [40]. The activity of the urease enzyme derived from different plant sources is summarized in Table 1. It should be noted that the Jack bean seeds have been used as a rich source of urease due to their high activity and commercial availability [41]. In 1926, Sumner [42] was the first to isolate the urease enzyme from jack beans (Canavalia ensiformis). In his work, he proposed that enzymes could be proteins devoid of organic coenzymes and metal ions. Blakeley [43] showed that urease is an enzyme in the form of a 
protein that contains a nickel ion cofactor. Figure 4 demonstrates the octahedral shape of the urease enzyme [43].

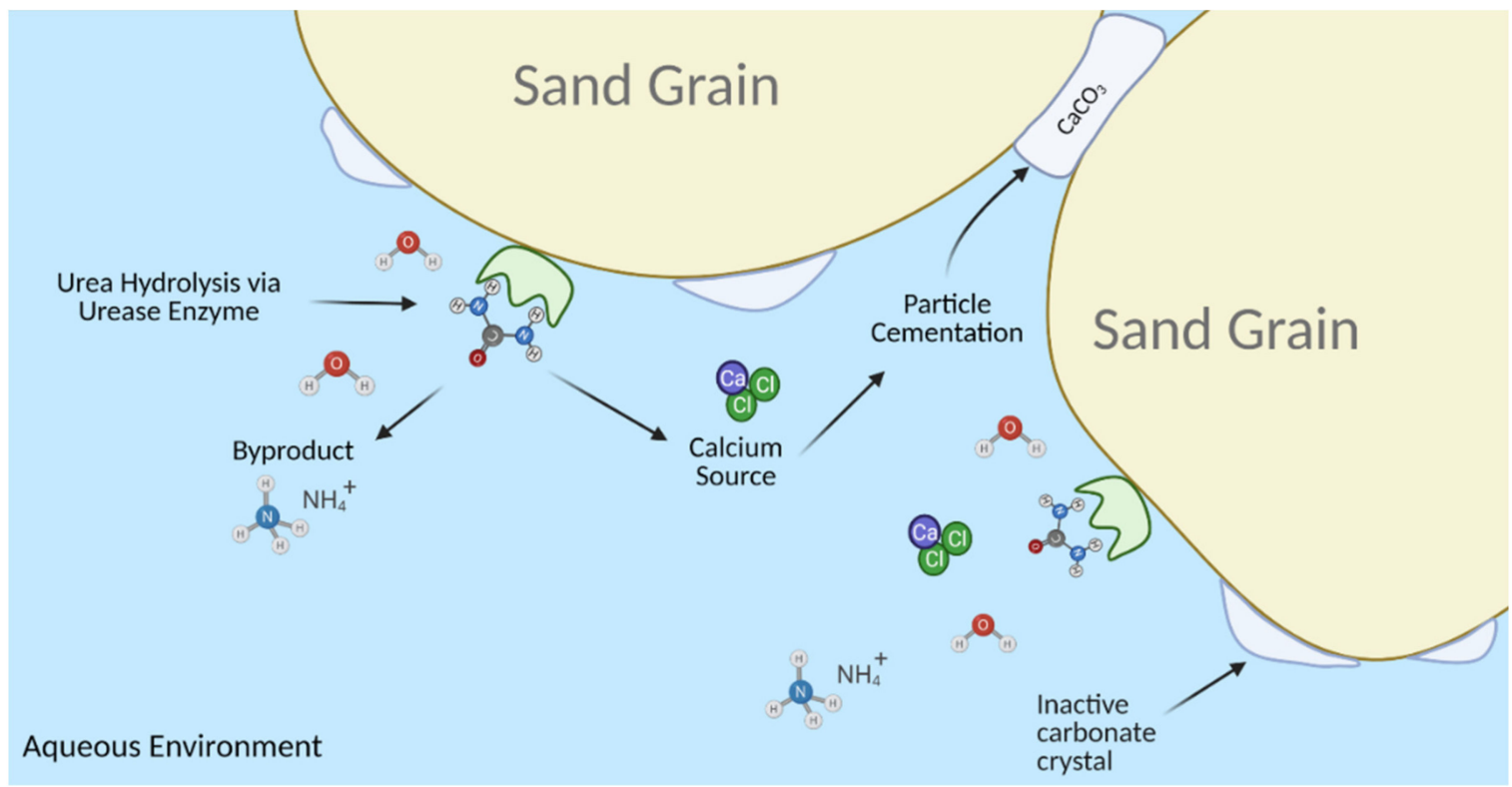

Figure 3. Overview of bio-inspired calcite precipitation using EICP.

Table 1. Urease activity based on its plant source [43].

\begin{tabular}{|c|c|}
\hline Enzyme Source & $\begin{array}{l}\text { Reported Enzyme Activity } \\
\quad\left(\mathrm{mg} \mathrm{NH} \mathrm{N}_{3} / \mathrm{g} / \mathrm{h} \text { at } 30^{\circ} \mathrm{C}\right)\end{array}$ \\
\hline Soya Bean Seeds & 360 \\
\hline Watermelon Seeds & 355 \\
\hline Pumpkin Seeds & 755 \\
\hline Jack Bean Seeds & 4871 \\
\hline
\end{tabular}

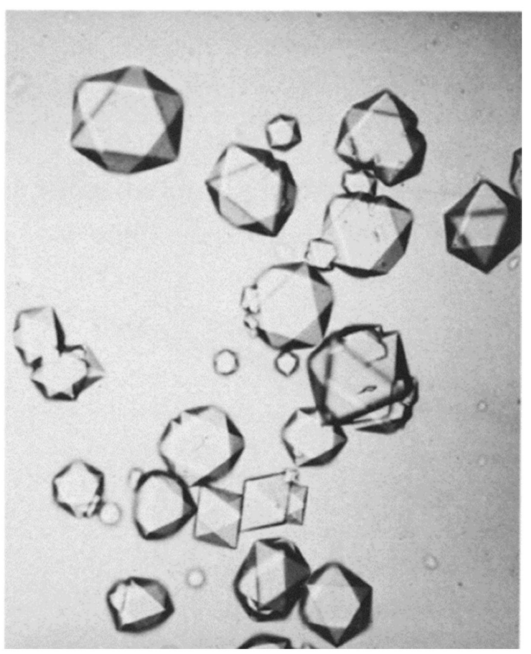

Figure 4. Micrographs of crystals from jack bean urease [43].

Pure urease can be costly, accounting for $57-98 \%$ of the total cost of the EICP cementing solution [44]. In an attempt to reduce the treatment cost, some researchers examined the use of crude urease enzyme extracted in the lab from jack bean [45], watermelon [46,47], soybean [48], and bacterial cells $[24,49,50]$ as cheap alternatives to costly lab-grade urease 
enzymes. Urease was extracted and purified from watermelon seeds through blending, filtration, and acetone fractionation. This method was able to produce carbonate precipitation in soil but was not cost-effective for large-scale applications due to the need for high energy and labour for de-husking the watermelon seeds [47]. Few studies have investigated the possibility of using jack bean meal or industrial grade urease for soil improvement [51-53]. Furthermore, Hoang et al. [24,49] employed a unique sonication approach that lyses Sporosarcina pasteurii bacteria cells in order to release their intracellular urease enzyme. The rapid growth of bacteria outside the soil can be promising for the commercial production of the enzyme. Khodadadi et al. [45] investigated the use of crude jack bean extracted with low purity in deionized water as the source of the enzyme without the need for extra fractionation steps or chemical extraction solution to get the purified extracts. Javadi et al. [54] investigated the use of lyophilization through freeze and drying the crude enzyme extract to a powder to facilitate storage and transportation of the extracted enzyme. Results have shown that the lyophilized crude extract has maintained its activity for up to a year with minimal loss in activity and longer than commercial urease enzyme.

It should be noted that the effectiveness of the EICP depends highly on the urease source and activity, which widely vary with the environment $\mathrm{pH}$, temperature, and concentration. Several researchers have used a variety of additives to the EICP cementing solution to improve the EICP performance such as biopolymers, hydrogels, and milk [55-57]. Appendix A Table A1 shows a comprehensive summary of the studies found in the literature in which different urease sources were used in the enzymatic bio-mineralization and the corresponding reported activity for each urease source. Appendix A also shows the additive used to stabilize urease and enhance the EICP soil treatment in each study.

\section{Factors Affecting Carbonate Crystallization in EICP Treatment}

The urea hydrolysis involves the breakdown of urea in water. The result of this reaction forms calcite in the presence of a calcium source. The reaction can be $10^{14}$ times faster than the chemical (un-catalysed) urea hydrolysis in the presence of a catalyst (urease enzyme) [43]. The improvement in EICP treatment is based on the precipitation of calcium carbonate within the treated soil matrix. It is thus important to shed light on the crystallographic patterns, such as size, shape, and distribution of precipitates, since they play a significant role in defining the mechanical properties of EICP bio-cemented soils $[44,58,59]$. The main factors that affect crystallization are the temperature, urease activity, $\mathrm{pH}$ level of the cementing solution, and concentration of cementation solution. These factors are discussed in some detail below.

\subsection{Effect of Urease Enzyme Activity and Concentration}

Both the enzyme concentration and urease activity have a significant effect on EICP treatment. The enzyme concentration is routinely represented as grams of enzyme per liter of cementing solution $(\mathrm{g} / \mathrm{L})$. The urease activity unit is usually represented as $\mathrm{U} / \mathrm{g}$, which means the $\mu \mathrm{mol}$ of urea hydrolysed per minute by $1 \mathrm{~g}$ of urease; this property depends mainly on the enzyme source and extraction method [40]. The literature on EICP highlighted the importance of finding the optimum amount of urease concentration to fully consume substrate (urea) in the solution. This optimization is essential to achieve high hydrolysing efficiency and reduce the cost of treatment. Several researchers have conducted the optimization based on increasing the precipitation ratio ( $\mathrm{PR} \%)$, defined as the carbonate precipitated mass over the maximum theoretical carbonate precipitation mass, calculated based on the EICP solution constituents. Several studies on the optimization of enzyme concentration have utilized electrical conductivity (EC) measurements of the EICP cementing solution as an index of the ionic strength of the solution (concentration of the chemical constituents).

As shown in Figure 5, Neupane et al. [60] found that the precipitation ratio, in the case of EICP solution with an equal molar of urea and calcium chloride with a calcium 
chloride concentration of $0.5 \mathrm{M}$, rapidly increased with the increase in urease enzyme concentration until reaching a urease concentration of $2.0 \mathrm{~g} / \mathrm{L}$. Increasing the concentration of enzyme more than $2.0 \mathrm{~g} / \mathrm{L}$ led to a slow and gradual increase in precipitation ratio up to a maximum of $90 \%$ at a concentration of $3.0 \mathrm{~g} / \mathrm{L}$. Further increase in the enzyme concentration led to a slightly lower precipitation ratio. However, in the same study and for a higher concentration of calcium chloride $(1 \mathrm{M})$ of equimolar EICP solution, the increase in enzyme resulted in a continuous increase in PR\%. Moreover, Almajed et al. [61] reported that an increase in the enzyme concentration, up to $6 \mathrm{~g} / \mathrm{L}$, led to an increase in the precipitation ratio regardless of the EICP solution. Almajed et al. [61] reported an optimal enzyme concentration of $3 \mathrm{~g} / \mathrm{L}$. Finally, Song et al. [2] showed a similar trend of increasing the precipitation rate with the increase of enzyme concentration (see Figure 5).

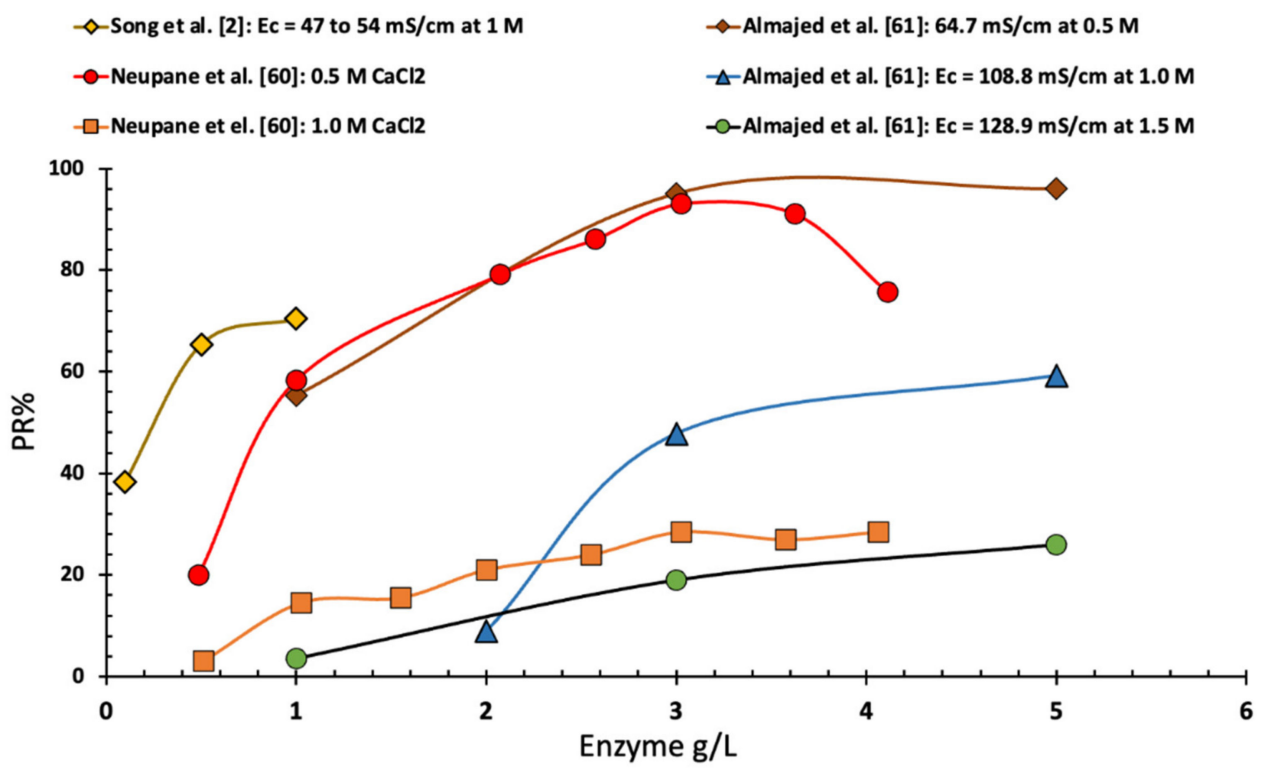

Figure 5. Change in precipitation ratio vs. enzyme concentration (data collected from several sources).

Carmona et al. [62] claimed that using $8 \mathrm{kU} / \mathrm{L}$ of urease concentration, the increase in urea- $\mathrm{CaCl}_{2}$ concentration beyond $0.5 \mathrm{~mol} / \mathrm{L}$ lowered the amount of hydrolysed urea, thereby yielded a lower mass of calcium carbonate precipitation. Carmona et al. [62] attributed this to the increase of reagents concentration that may inhibit the catalysation capacity of urease. Moreover, the same amount of urease concentration $(8 \mathrm{kU} / \mathrm{L})$ mixed with urea- $\mathrm{CaCl}_{2}$ concentration of $0.25 \mathrm{~mol} / \mathrm{L}$ led to less calcite precipitation; thus, an excessive amount of the urease enzyme compared to the concentration of urea- $\mathrm{CaCl}_{2}$ may suppress its catalysing efficiency according to this study.

Song et al. [2] studied the effect of urease concentration to evaluate the precipitation rate and quantify calcium carbonate formation with respect to time. They showed that the calcium carbonate precipitation rate can be increased by the urease concentration increase. Ahenkorah et al. [63] performed SEM imaging on calcium carbonate tube precipitates. SEM images showed that $\mathrm{CaCO}_{3}$ precipitates from a solution containing low active urease enzyme $(3500 \mathrm{U} / \mathrm{g})$ have a disordered and anhedral calcite crystal, while the high active urease enzyme $(40,150 \mathrm{U} / \mathrm{g})$ resulted in euhedral and agglomerated rhombohedral calcite morphology.

Generally speaking, the effect of increasing the enzyme concentration can be illustrated using enzyme kinetics, which was first proposed by Michaelis and Menten [64] to study the factors affecting the speed of the enzyme reaction [65,66]. According to Michaelis and Menten's [64] model, the increase in the enzyme concentration results in a linear increase in the initial reaction velocity $\left(\mathrm{V}_{\mathrm{o}}\right)$, as shown in Figure 6a. The EICP reaction velocity, after mixing the enzyme with substrate: urea, can be monitored by continuously measuring the concentration of the hydrolysis product $\left(\mathrm{NH}_{4}{ }^{+}\right)$formation over time [67]. 
Few studies have used this approach in evaluating the EICP kinetics and mostly relied on PR. Miftah et al. [68] monitored the $\mathrm{NH}_{4}{ }^{+}$concentration over time, as shown in Figure 6b, showing slower rate hydrolysis of urea (production of $\mathrm{NH}_{4}^{+}$) with time. The slower rate of hydrolysis with time can be attributed to the consumption of the substrate (urea) with time and therefore it becomes a limiting factor or due to denaturalization of enzyme due to the presence of inhibitors. If three enzyme concentration levels (A, B, and C) are considered, as shown in Figure $6 \mathrm{a}$, an increase in the initial reaction velocity $\left(\mathrm{V}_{\mathrm{o}}\right)$ will be obtained. This increase in reaction rate due to the increase in enzyme concentration results in a faster rate of hydrolysis and reduction of time needed to reach $100 \%$ PR. This may illustrate the different optimum enzyme concentrations reported from different studies, as most of these studies did not consider the reaction kinetics and evaluated the EICP outputs after constant time. For example, Almajed et al. [61] and Neupane et al. [60] evaluated the PR after $72 \mathrm{~h}$ assuming the reaction is concluded. However, as illustrated in Figure 6a, this may not be always true and it may need a longer time for the reaction to conclude especially at lower enzyme concentrations. Therefore, it is recommended in future studies to include the enzyme kinetics in the optimization process based on monitoring $\mathrm{NH}_{4}{ }^{+}$production over time, not just carbonate precipitation mass and precipitation ratio.

(a)

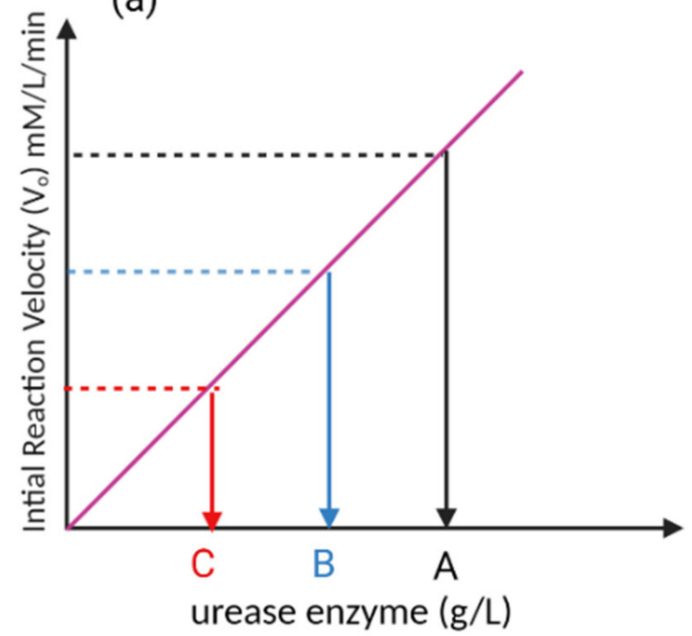

(b)

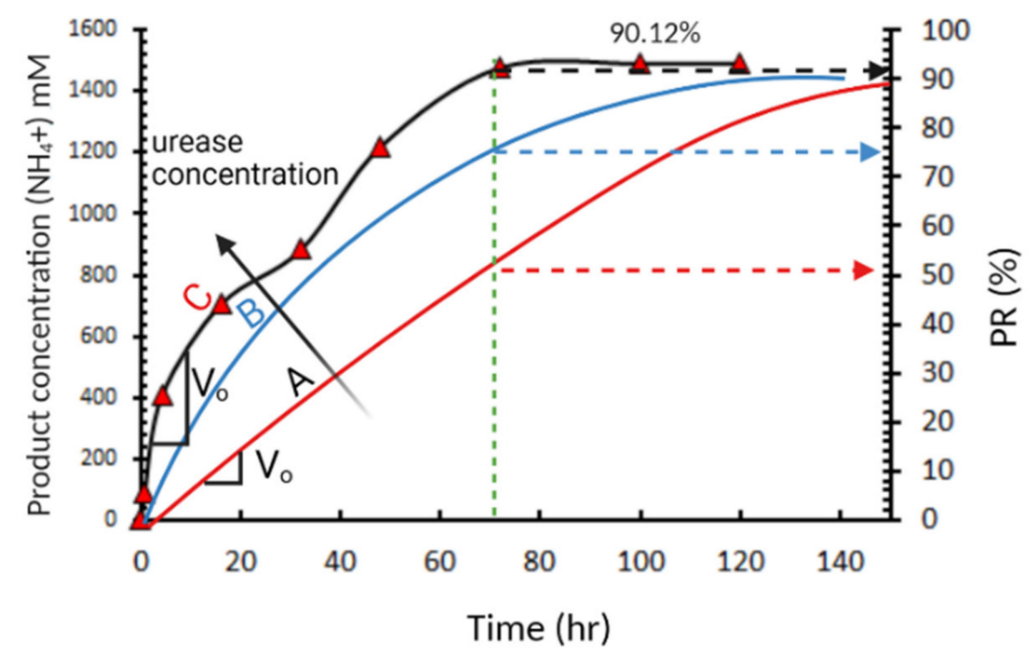

Figure 6. A typical enzyme-catalysed reaction (a) initial reaction velocity versus enzyme concentration (typical reaction based on Michaelis and Menten model) (b) product formation over time (data adopted from Miftah et al. [68]).

\subsection{Chemical Constituents Concentrations}

Optimizing EICP chemical constituents is desirable to achieve a cost-effective cementing solution while maintaining a high amount of carbonate precipitation. It is believed that the amount of precipitation and reagents concentration has a significant effect on the hydrolysis process. Various studies have reported different optimum concentrations of chemical constituents for the EICP solution to maximize carbonate precipitation. Nemati \& Voordouw [9], and Nemati et al. [69] reported an increase in carbonate precipitation with the increase in urea and calcium chloride concentration up to a certain level. Yasuhara et al. [26] reported that using a higher amount of calcium source led to a higher degree of precipitation formation. However, Neupane et al. [60] reported that using a lower concentration of constituents (equimolar of urea and calcium chloride) can lead to a higher precipitation ratio; they reported that $0.5 \mathrm{~mol} / \mathrm{L}$ had a precipitation ratio of $80 \%$, which was higher than the PR achieved at $1.0 \mathrm{~mol} / \mathrm{L}$. Chandra \& Ravi [70] studied the optimum combination of urea and calcium chloride in a bench-level tube test and evaluated the precipitation by gravimetrically measuring the amount of precipitated calcium carbonate. They prepared several equimolar concentrations of urea- $\mathrm{CaCl}_{2}$ of $0.25,0.5,0.75$, 
1.0 , and $1.25 \mathrm{~mol} / \mathrm{L}$ with $0.2 \mathrm{~g} / \mathrm{L}$ of urease enzyme. It was concluded that the increase in urea- $\mathrm{CaCl}_{2}$ concentration may inhibit the activity of urease and reduce the precipitation amount of calcium carbonate, hence, reducing the hydrolysing efficiency. The fact that the increase of urea- $\mathrm{CaCl}_{2}$ in the concentration may inhibit the activity of the urease enzyme was also reported by Carmona et al. [62]. Almajed et al. [61] correlated the efficiency of the urease enzyme with the solution EC that is controlled by the ratio and concentration of urea- $\mathrm{CaCl}_{2}$. It was found that for each enzyme concentration, there is a critical EC value representing the maximum concentration of calcium chloride and urea, which results in nearly complete precipitation. Moreover, beyond a certain threshold value for the EC reading, the precipitation ratio dropped drastically. Finally, Ahenkorah et al. [63] found that the rate of change in electric conductivity increases with the increase in urease enzyme concentration regardless of the activity.

The effect of the substrate (urea) concentration in the EICP cementing solution can be illustrated using the enzyme kinetics model proposed by Michaelis and Menten [64]. In this model, the rate of hydrolysis is considered as hyperbolic with the change of the hydrolysis rate $(\mathrm{V})$ increases with the substrate concentration [S] (urea concentration in this case) until it reaches an asymptote at $\mathrm{V}=\mathrm{V}_{\max }$, as shown in Figure 7a. Where $\mathrm{V}$ is defined as the rate of change in the product concentration $[\mathrm{P}]\left(\mathrm{NH}_{4}{ }^{+}\right.$in this case). Equation (8) defines the rate of hydrolysis based on the Michaelis constants $K_{m}$, and $V_{\max }$.

$$
\mathrm{V}=\frac{\mathrm{d}[\mathrm{P}]}{\mathrm{dt}}=\frac{\mathrm{V}_{\max } \cdot[\mathrm{S}]}{\mathrm{K}_{\mathrm{m}}+[\mathrm{S}]}
$$

This model suggests that the increase in substrate (urea) concentration increases the rate of hydrolysis which agrees with the reported behaviour in several studies (e.g., $[9,69])$. However, the rate of urea hydrolysis (V) is also affected by inhibitors that may affect the rate of carbonate precipitation and even denaturalize the urease enzyme. These inhibitors can be categorized as competitive inhibitors where $V_{\text {max }}$ remains the same and non-competitive inhibitors where $\mathrm{V}_{\max }$ changes depending on the concentration of inhibitor, as shown in Figure 7b [67]. Recently, Ahenkorah et al. [71] introduced a normalized enzyme concertation term $\left[E_{S}\right]$ (defined as enzyme concentration multiplied by enzyme activity) to explain the effect of Enzyme and substrate concentration [S] on the PR\%. PR\% was found to exhibit a non-linear correlation with the ratio $\left[E_{S}\right] /[S]$ with an optimum value of $20 \mathrm{kU} / \mathrm{mol}$ beyond which no increase in PR\% was reported.

(a) $\quad \mathrm{V}=\frac{\mathrm{d}[\mathrm{P}]}{\mathrm{dt}}=\frac{\mathrm{V}_{\max } \cdot[\mathrm{S}]}{\mathrm{K}_{\mathrm{m}}+[\mathrm{S}]}$

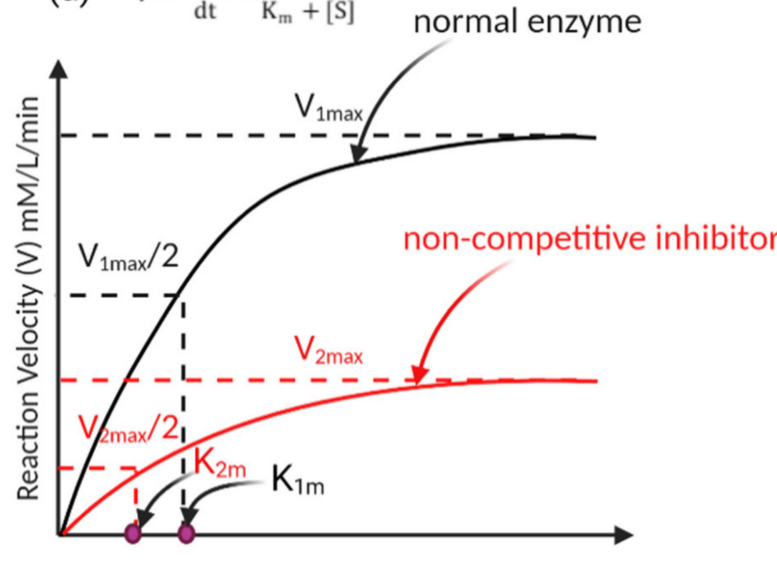

substrate (urea) concentration (g/L) (b)

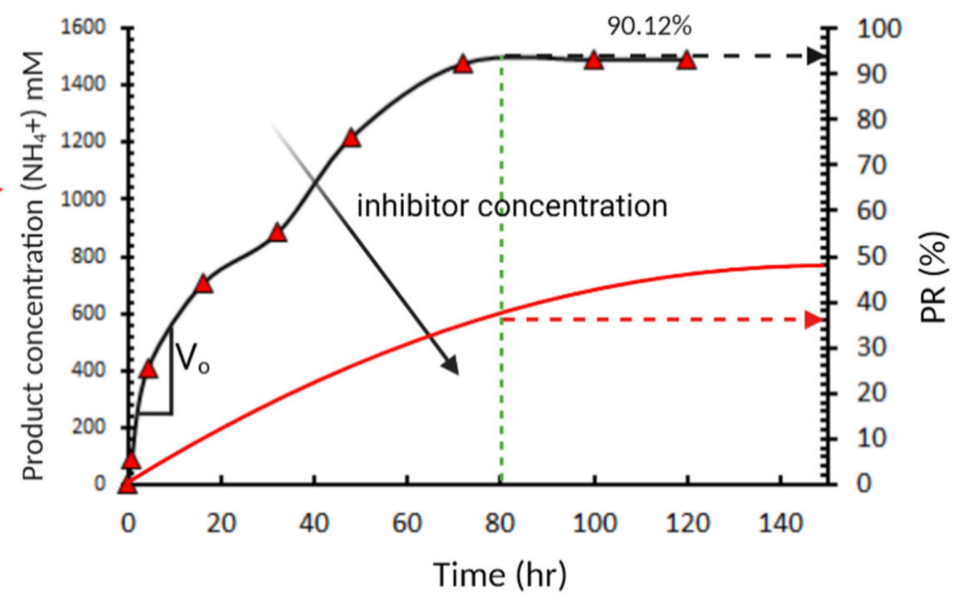

Figure 7. A typical enzyme-catalysed reaction (showing the effect of inhibitors in an enzyme-catalysed reaction) (a) initial reaction velocity versus substrate concentration [S] (typical reaction based on Michaelis and Menten model); (b) product formation over time (data for normal enzyme adapted from Miftah et al. [68]). 
Several studies have shown that ammonium ions (a by-product from the hydrolysis process) in the EICP solution act as a non-competitive inhibitor [64,72,73], as shown conceptionally in Figure 7. This may illustrate the reported reduction in carbonate precipitation beyond a specific threshold of substrate (urea) concentration (e.g, [61]). This may also be illustrated more in Hamdan's [58] study in which a series of experiments were conducted to define the optimum ratio of (urea to $\mathrm{CaCl}_{2}$ ) in EICP solution. Hamdan [58] compared the ureolysis efficiency at low $(0.1$ to $0.6 \mathrm{M})$ and high $(1.0$ and $6.0 \mathrm{M})$ substrate concentrations, and the test was conducted by preparing EICP solutions with varying concentrations and ratios between the reagents. Although a high concentration solution yielded more calcium carbonate than a low concentration, it was found that the lower concentration had a better ureolysis efficiency (higher PR). Figure 8 shows the relationship between the initial ratio of urea to $\mathrm{CaCl}_{2}$ and the $\mathrm{pH}$ of the EICP cementing solution. Hamdan [58] showed that this drop in $\mathrm{pH}$ has a role in reducing the hydrolysis rate. High $\mathrm{pH}$ leads to an increase in calcium carbonate precipitation that limits the transformation of ammonia into the acidic form $\left(\mathrm{NH}^{+}{ }_{4}\right)$, thereby preventing the reversal of calcium carbonate formation.

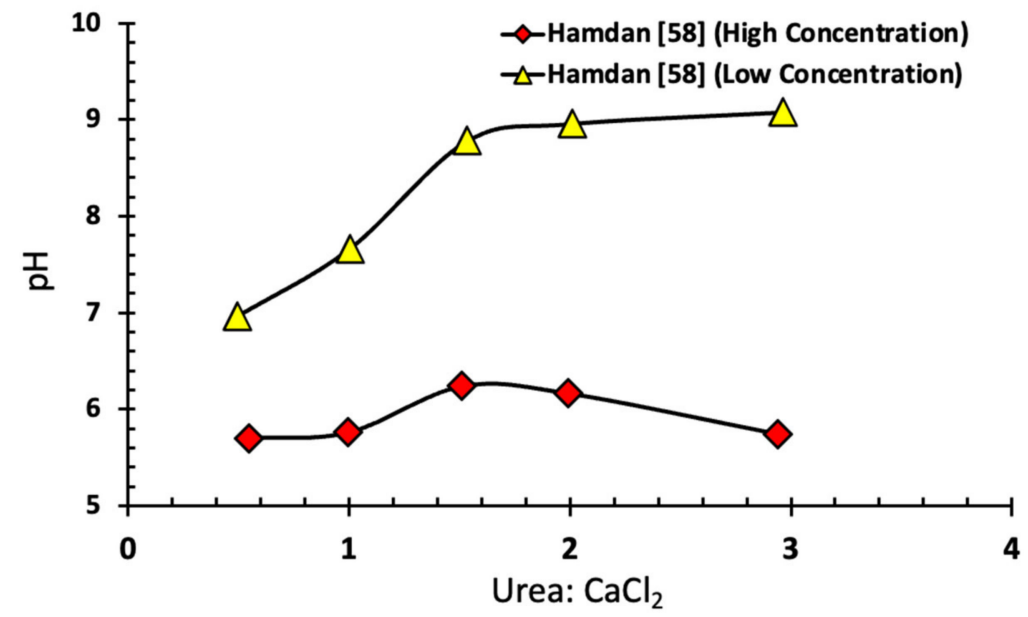

Figure 8. Relationship between initial $\mathrm{CaCl}_{2}$-urea ratio, and $\mathrm{pH}$ for high and low substrate concentration [58].

The above studies may suggest that an increase in substrate (urea) concentration will increase the hydrolysis reaction rate to a specific threshold value for the substrate concentration (not clearly defined in the literature). After reaching this threshold, a reduction in hydrolysis rate due to the increase in non-competitive inhibitor concentration $\left(\mathrm{NH}_{4}^{+}\right)$was reported. However, further studies are still required to thoroughly define this threshold based on the substrate (urea concentration), urea: $\mathrm{CaCl}_{2}$, and urease enzyme activity and source.

\subsection{Temperature}

Few studies have investigated the effect of temperature on the behaviour of EICP treated soils. Nemati \& Voordouw [9] reported that an increase from 20 to $50{ }^{\circ} \mathrm{C}$ enhanced the production rate of calcium carbonate from 0.038 to $0.34 \mathrm{~g} / \mathrm{L} / \mathrm{h}$. In another study by Zhao et al. [74], a $26 \%$ decrease in permeability was measured for EICP-treated soil at $30^{\circ} \mathrm{C}$ compared to that at $22{ }^{\circ} \mathrm{C}$. Arab et al. [53] have studied the effect of temperature during the curing of EICP treated bio-specimens. They reported that specimens cured at $10^{\circ} \mathrm{C}$ exhibited the lowest UCS results with an average UCS of $669 \mathrm{kPa}$ while specimens cured at $25^{\circ} \mathrm{C}$ was and $40{ }^{\circ} \mathrm{C}$ had a UCS of 1411 and $1537 \mathrm{kPa}$, respectively. They also attributed this reduction in compressive strength at lower temperatures to the reduction in urease activity which has resulted in lower carbonate precipitation. 


\section{4. $p H$ Level}

The entire process of calcium carbonate precipitation during hydrolysis is highly dependent on the overall $\mathrm{pH}$ level of the whole environment. A sufficiently large increase in the environment $\mathrm{pH}$ (alkalinity) is necessary to shift the carbonate equilibrium from $\mathrm{CO}_{2}$ to $\mathrm{HCO}_{3}$ to $\mathrm{CO}_{3}^{2-}$ and then precipitate $\mathrm{CaCO}_{3}$ in the presence of $\mathrm{Ca}^{2+}$. This change in the $\mathrm{pH}$ level occurs due to the formation of $\mathrm{OH}^{-}$, which is a by-product of ammonium generation $\left(\mathrm{NH}_{4}^{+}\right)$that raises the $\mathrm{pH}$ and provides favourable conditions for calcium carbonate precipitation [1,75]. Jacob [76] explained the relationship between carbonate precipitation and $\mathrm{pH}$ in water, showing that generating more carbonate $\mathrm{CO}_{3}{ }^{2-}$ usually occurs at a high value of $\mathrm{pH}$. Furthermore, maintaining a high $\mathrm{pH}$ value $(>9.0)$ helps in increasing calcium carbonate saturation and drives the precipitation reaction towards completion. Speciation of ammonia-ammonium shifts toward ammonium, which increases the $\mathrm{pH}$ and decreases the possibility of reversing the reaction, since calcium carbonate dissolves in an acidic environment at a $\mathrm{pH}$ lower than 7.0 [75]. Moreover, the activity of the urease is also dependent on the system $\mathrm{pH}$. The optimum $\mathrm{pH}$ that maintains the urease activity is found to be 6.9 [77].

\section{Soil Cementation via EICP}

The observation of sand-forming sandstones through the precipitation of calcium carbonate paved the way for exploring new methodologies under the biogeotechnology branch such as EICP. Several recent studies have demonstrated the transformation of loose sand into bio-cemented sand (see Figure 9). In this section, several studies that showed the successful application of EICP as a cementing binder are presented.

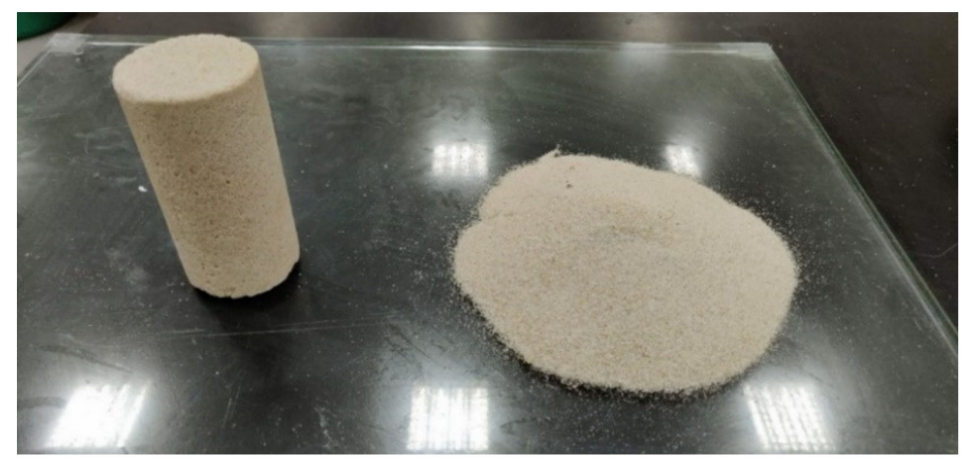

Figure 9. Comparison of sand before (right) and after (left) bio-cementation via EICP.

\subsection{Application Methods}

To achieve the full potential of EICP-based soil improvement, carbonate cementation must be concentrated at the contact points of soil particles. The improper distribution of carbonate precipitation may lead to failure in soil cementation. Several methods have been proposed in the literature to introduce EICP cementing solution into the soil matrix, including: (1) injection method; (2) mix-and-compact; (3) surface percolation; and (4) spraying. The soil grain and pore size have a significant effect on selecting the proper application method of EICP cementing solution and each method has also been used for specific applications.

\subsubsection{Injection Method}

Hamdan [58] used the injection method to treat Ottawa (20-30) silica sand columns using the EICP cementing solution. The soil was injected dry and saturated, and the UCS test results of treated soil were found to be in the range of 35 to $125 \mathrm{kPa}$. Kavazanjian et al. [78] used EICP cementing solution as a grout for soil nails. The injected cementing solution consisted of $0.87 \mathrm{M}$ urea, $0.5 \mathrm{M} \mathrm{CaCl}_{2}-2 \mathrm{H}_{2} \mathrm{O}, 0.85 \mathrm{~g} / \mathrm{L}$ low-grade urease enzyme, and $4.0 \mathrm{~g} / \mathrm{L}$ stabilizer (non-fat milk). The EICP solution was injected into perforated PVC tubes 
with a diameter of $9.5 \mathrm{~mm}$ and a length of $330 \mathrm{~mm}$ using a $60 \mathrm{~mL}$ syringe. The tubes were buried in a wooden box full of F-60 silica sand. After 5 days of curing, the stability of the treated soil mass was examined using weights applied to the top of the box after disassembling one of the wooden box faces. The stabilized soil mass in the box remained stable without any sign of cracking or instability. However, uneven carbonate distribution along the soil column was reported. Neupane et al. [60] also utilized injection and reported an increase in precipitation near the injection point, which led to further decrease in porosity and effectiveness of precipitation in latter injections, thereby requiring higher pressure in the injection tube to maintain the rate of flow downstream of the treated soil column. Martin et al. $[37,79]$ utilized a tube-à-manchette (TAM) permeation grouting technique to inject EICP cementing solution to create $0.3 \mathrm{~m}$ diameter $\times 0.75 \mathrm{~m}$ long columns of treated sands. A target value of $500 \mathrm{kPa}$ established from laboratory testing was achieved in the field after four cycles of treatment.

One of the issues in the bio-cementation solution for both (MICP and EICP) used for grouting is the low viscosity of the solution since the cementing solution is water-based [80]. This reduces the efficiency of injection as the solution drain off rapidly. Therefore, several researchers proposed using biopolymer as additives to improve groutability of the cementing solution and uniformity of carbonate precipitation. The treatment with biopolymers alone was proposed for the compaction grouting or deep cement mixing (DCM) method due to its high viscosity [80]. Consequently, biopolymers were shown to improve the EICP cementing solution viscosity without affecting the hydrolysis process [81]. Examples of these biopolymers are sodium alginate [82], and xanthan gum [44,81,83]. In addition, the pre-injection of sodium bentonite evidenced a uniform improvement for columnar and mass EICP stabilization [58].

\subsubsection{Mix and Compact}

In this method, the EICP cementing solution is mechanically mixed all together with the soil to be treated and then compacted to the desired compaction level. This method is suitable for several field applications such as pavement construction and surficial soil improvement. Yasuhara et al. [26] pre-mixed the urease powder with Toyoura sand to achieve a homogenous mix before injecting the soil with the reagents of EICP. This application method achieved UCS of up to $1.6 \mathrm{MPa}$ after several injections. Hamdan [58] used the mix-and-compact approach to treat sand specimens and reported a compressive strength from 392-529 kPa compared to 35-125 kPa in the case of injection. In both Almajed [44] and Almajed et al. [61], a similar approach to Hamdan [58] was followed to treat Ottawa (20-30) silica sand. Almajed [44] showed that the EICP treated soil strength via mix and compact is highly dependent on the soil relative density and soil particle size.

\subsubsection{Surface Percolation}

Surface percolation is simply applied by pouring the EICP cementing solution on the top surface of the sample. Hamdan [58] used the surface percolation method to treat sand columns of medium-coarse Ottawa (20-30) silica sand and medium grain F-60 silica sand. The UCS test results of the treated soils were in the range of $38-210 \mathrm{kPa}$ with a carbonate content of $1.6-2.0 \%$. Similar to the injection method, multiple applications were required to increase the carbonate precipitation and increase the compressive strength of the treated soil. Almajed et al. [61] reported that the surface percolation method resulted in UCS of $100 \mathrm{kPa}$ at $1.2 \% \mathrm{CaCO}_{3}$ and one treatment cycle, whereas four treatment cycles led to $465 \mathrm{kPa}$ at $4.6 \% \mathrm{CaCO}_{3}$. Based on the analysis of SEM images of the treated soils, Almajed et al. [61] showed accumulation of precipitates between the soil particles along the flow path of the cementing solution during percolation, which may suggest that the surface percolation method facilitated nucleation and, consequently, the growth of calcite crystals between soil particles, hence providing better binding than the mix-and-compact method (Figure 10). However, the mix-and-compact method showed a more uniform distribution of carbonate precipitation compared to the surface percolation technique (Figure 10). 


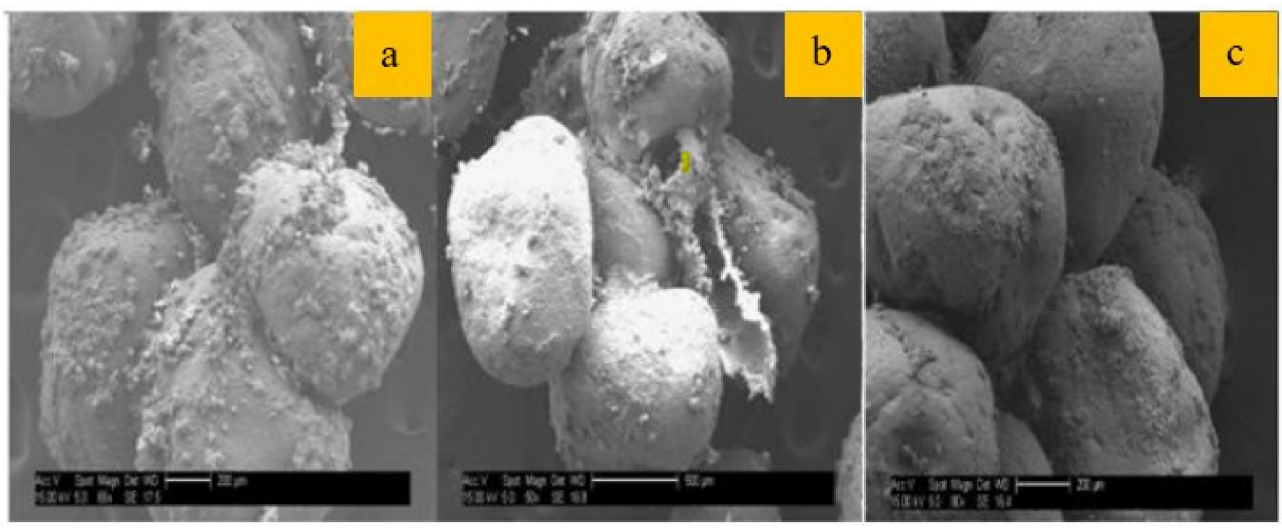

Figure 10. Comparison of calcium carbonate precipitation distribution based on application method: (a) mix and compact (carbonate content: 1.8\%), (b) percolation (carbonate content: 1.79\%); and (c) injection (carbonate content: 1.8\%) [44].

\subsubsection{Spraying}

EICP spraying is usually used when the cementing solution is intended to be kept at the surface of the treated soil where only strengthening of the surface is required. Consequently, this application method is suitable for water erosion resistance and fugitive dust control. Knorr [29] applied a spraying method for dust control using two sprayers for the urea- $-\mathrm{CaCl}_{2}$ and enzyme solutions to avoid any losses in the precipitation since the precipitation process starts within minutes after mixing. Knorr [29] sprayed $200 \mathrm{~mL}$ of EICP cementing solution on $23 \mathrm{~cm}$ pans full of soil and observed that the soil surface could withstand up to $24.4 \mathrm{~m} / \mathrm{s}$ of wind speed without any detachment in a wind tunnel test. Hamdan and Kavazanjian [27] used a hand-held plastic bottle sprayer to apply EICP cementing solution on the soil surface. They separated the solutions of urea-CaCl${ }_{2}$ and enzyme and compared them with a pre-mixed EICP solution. Contrary to Knorr [29], the premixed EICP solution showed better erosion resistance than the separated solution. The pre-mixed EICP solution showed no sign of soil detachment at a wind speed of $25 \mathrm{~m} / \mathrm{s}$. Almajed et al. [32] sprayed both EICP cementing solution and sodium alginate biopolymer on several types of soils for wind erosion resistance, and substantial improvement was achieved compared to soils sprayed with EICP cementing solution alone. Miao et al. [84] demonstrated how EICP can withstand several cycles of wetting and drying after EICP spray application while still having nearly the same wind erosion resistance ability. It was shown also that increased multiple passes of spray from 2 to 6 can have a respectable reduction in weight loss after wind tunnel exposure. Wu et al. [30] successfully utilized urease extracted from soybean to spray EICP cementing solution on coal dust from mining activities to suppress fugitive dust.

\section{Geotechnical Properties of EICP Treated Soils}

The purpose of any ground improvement technique is to improve certain geotechnical characteristics of soils (e.g., increase soil shear strength, reduce settlement, reduce soil permeability, slope stability, increase soil bearing capacity, and improve soil resistance to liquefaction) for construction or infrastructure developments. Therefore, successful ground improvement aims to alter the geotechnical property of soil in a controlled manner to achieve the desired response. In this section, the effect of EICP on several geotechnical properties of bio-treated soils is discussed.

\subsection{Hydraulic Conductivity}

The hydraulic conductivity of treated soils is an important parameter in evaluating the success of soil improvement techniques. The application of EICP treatment binds the soil particles and thus relatively decreases the hydraulic conductivity of treated soils. However, the extent of the reduction can be controlled based on the cementing solution 
used and the number of treatment cycles. Soil hydraulic conductivity is related to the soil packing density and the associated porosity since the soil mass behaviour depends on the macroscale particle-particle interactions [85].

The pore occupation in EICP treatment is a result of $\mathrm{CaCO}_{3}$ crystals that fill the space between soil particles, which causes a change in the soil pore volume and hence reduces soil hydraulic conductivity. Nemati and Voordouw [9] investigated the use of EICP to modify the soil porosity for oil recovery applications. They showed that the permeability of treated soil depends on the formation type of the carbonate and carbonate content, which depends on the concentration of enzyme and reactants concentration (urea and calcium chloride). Following the injection of the treatment mixture, the soil permeability decreased about $92 \%$ compared to untreated samples. A second injection of the treatment solution was applied and further decreased soil permeability by $73 \%$, resulting in a total reduction in soil permeability of $98 \%$. The study concluded that EICP treatment is very efficient in reducing the permeability of treated soils, especially for the sweeping of water in oil recovery applications.

Yasuhara et al. [26] found a linear relationship (on a semi-log scale) between the hydraulic conductivity and carbonate content. Neupane et al. [60] adopted a multi-physics reaction simulator to study the change in soil porosity over time during the calcite precipitation reaction; their simulation was capable of predicting the reduction in soil porosity and change in hydraulic conductivity.

Finally, Hoang et al. [24] compared the bio-cementation treatment of sandy soil permeability using both MICP and EICP for 8, 12, and 16 cycles of treatment. They found that increasing the treatment cycles increases the accumulation of carbonate crystals, which further clog the soil pores and decrease the soil hydraulic conductivity. The hydraulic conductivity of the specimens treated using the EICP cementing solution at 16 cycles showed a maximum reduction of $90 \%$ compared with the original untreated soil, while a $99 \%$ reduction in the hydraulic conductivity was attained in the case of MICP-treated soils at the same number of cycles.

\subsection{Treated Soil Strength}

Several testing protocols have been used in the literature to evaluate the enhancement in EICP-treated soil strength depending on the envisioned application. The shear and compressive strength of EICP treated soils are discussed in this section.

\subsubsection{Unconfined Compressive Strength (UCS)}

UCS is one of the most common tests used to evaluate bio-cemented sand in general soils due to the simplicity and efficiency of this test $[5,10,24,26,58,60,61,86-90]$. Several factors can affect the UCS magnitude, including cementing solution, soil type, and the number of treatment cycles. Several researchers have found a strong correlation between the carbonate content and UCS of EICP-treated soils [44,53,58,61,91]. Therefore, in order to improve treated soil compressive strength, several researchers have used multiple cycles of treatment with EICP solution to increase the amount of carbonate precipitation and hence increase soil compressive strength. Figure 11 shows data compiled from the literature for UCS against carbonate content. As shown in the figure the UCS shows a general increasing trend with carbonate content. As shown in the figure, the reported UCS values for EICP-treated soils found in the literature range between 17 to $6500 \mathrm{kPa}$ for carbonate content in the range from $0.5 \%$ to $17 \%$. This scatter in the data is attributed to the different conditions used in each study to produce the EICP treated soils, including the number of treatment cycles, EICP chemical constituent concentrations, soil type, soil density, and use of additives that enhance EICP cementing solution performance.

Figure 12 shows the effect of the number of EICP treatment cycles on the UCS of EICP treated soil. To achieve UCS of $6500 \mathrm{kPa} 29$ cycles of EICP treatment was needed. The data points from Ahenkorah et al. [92] showed a different trend with improved gain in treated soil strength with the number of EICP cycles. This reported improvement may be 
attributed to the use of non-fat powder milk as an additive to the EICP cementing solution in their study.

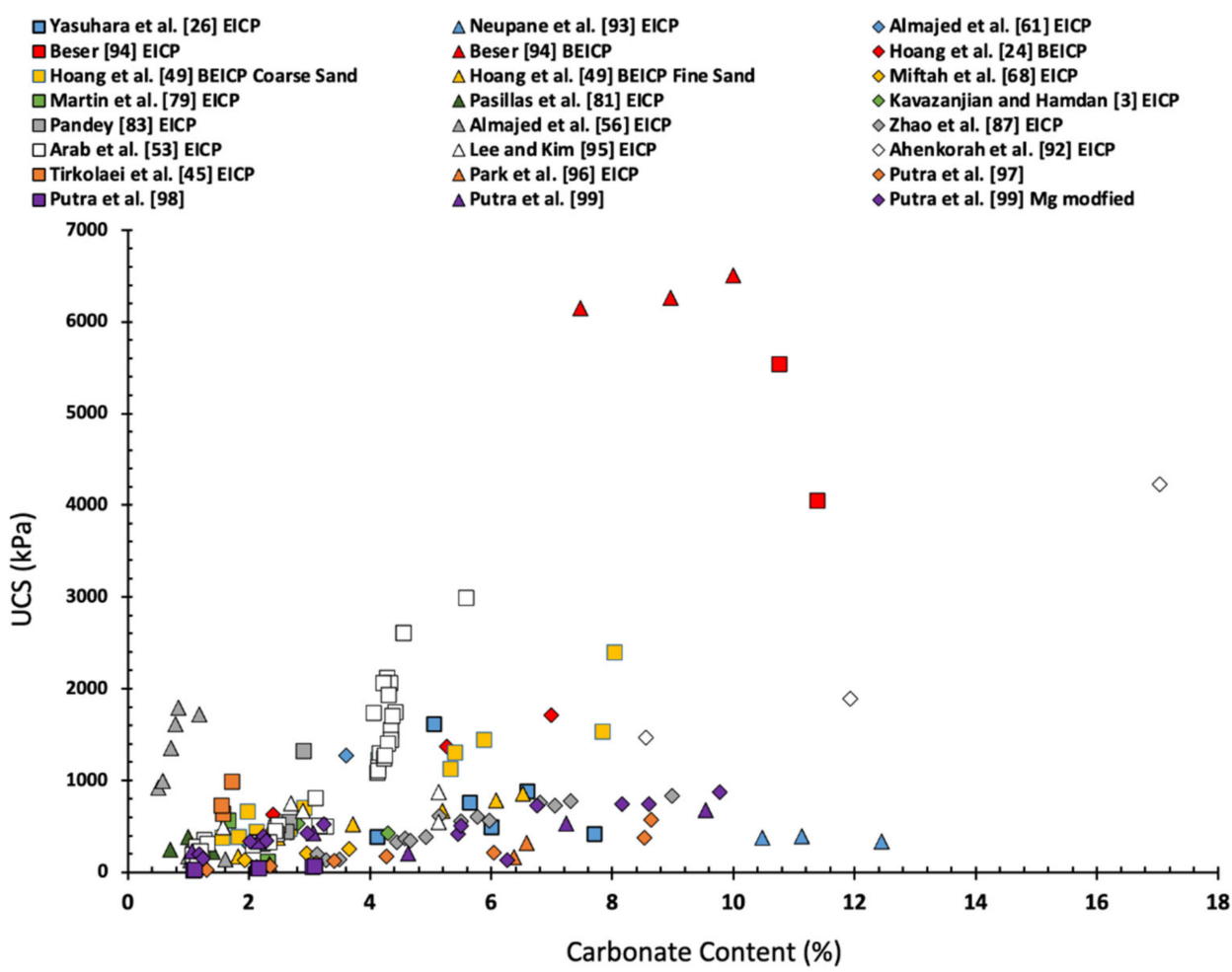

Figure 11. Effect of carbonate content on the UCS of EICP treated soils data adopted from several studies $[3,24,26,45,49,53,56,61,68,79,81,83,87,92-99]$.

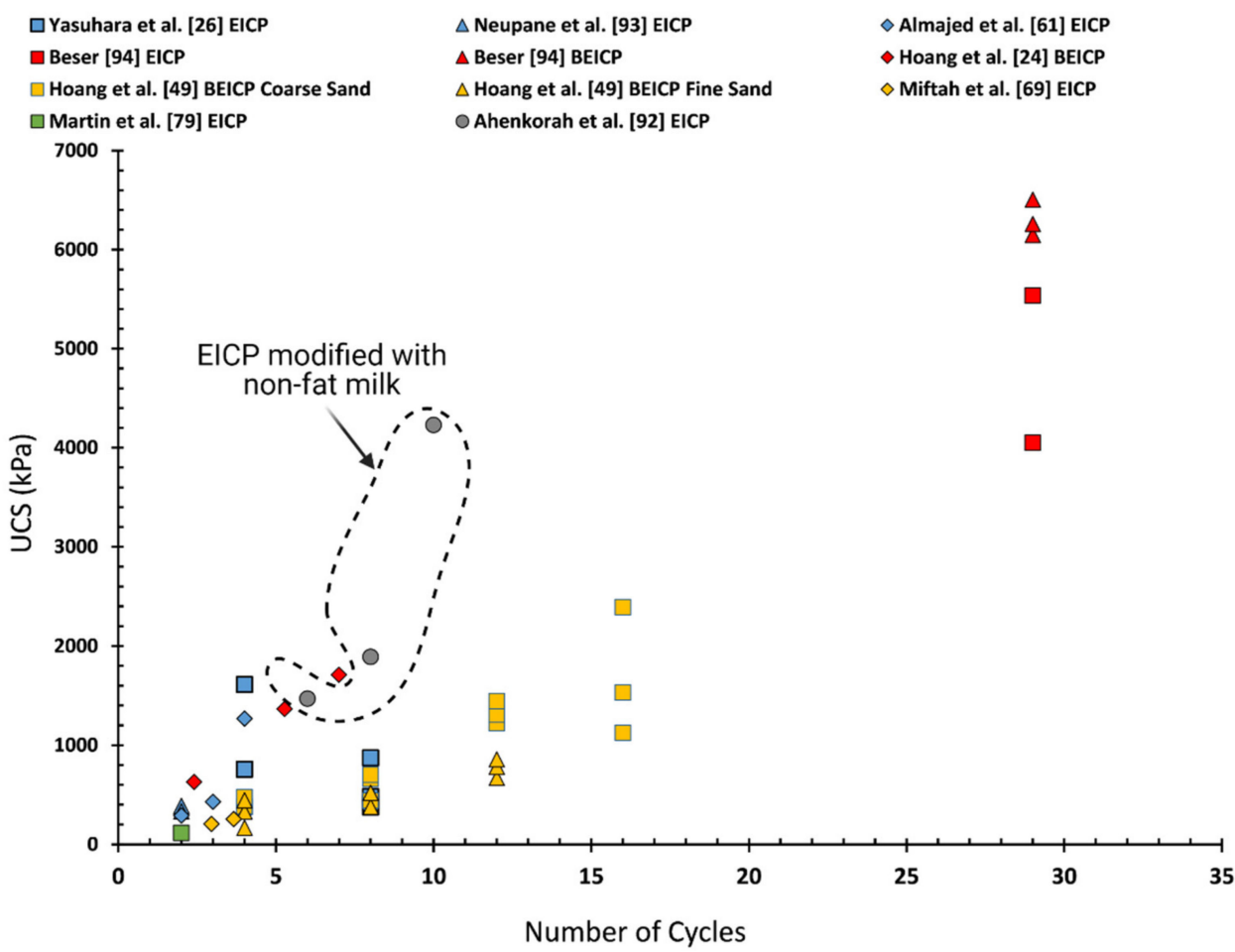

Figure 12. Effect of the number of EICP treatment cycles on UCS of EICP treated soils data adopted from several studies $[24,26,49,61,69,79,93,94]$. 
Figure 13a shows the UCS of EICP treated soils using only one cycle of EICP cementing solution against carbonate content. In this case, the range of UCS is $17 \mathrm{kPa}$ to $2900 \mathrm{kPa}$ with a carbonate content in the range from $0.5 \%$ to $8.9 \%$. The carbonate content is expected to be low in the case of one cycle of treatment and therefore the UCS is much lower compared to the case of multi-cycles of treatment. The scatter in the data collected in the case of one-cycle is attributed to the fact that researchers have used different techniques to enhance the EICP cementing solution to reach enough UCS in one cycle. Each improvement technique may have a different trend in terms of carbonate content against UCS. Figure 13b,c show the data for carbonate content against UCS for treated soil with modified and non-modified EICP cementing solution, respectively. The data in Figure $13 \mathrm{~b}$ shows a good correlation between the UCS and compressive strength. Almajed et al. [56] study results show that a substantial increase in the UCS results at a much lower carbonate content of less than $1 \% \mathrm{CaCO}_{3}$ was observed. They attributed this improvement to the casein proteins non-fat milk that bind the calcium ions in the EICP solution and then work as nucleation sites for the carbonate precipitation. Nevertheless, the results from the Almajed et al. [56] study have shown much higher compressive strength at such lower carbonate content compared to other studies that have also used non-fat milk powder in the EICP cementing solution. In Arab et al. [53] study, non-fat milk powder was used with relatively high molarity of urea (3 M) in the EICP cementing solution with urea to calcium chloride ratio of (1:0.67). As shown in Figure 13b the use of high molarity substrate has resulted in relatively higher carbonate precipitation and compressive strength. Figure 13c shows the results of the carbonate content versus UCS for EICP basic solution without any additives (i.e., basic EICP constituents of urea, calcium chloride, and urease were used). As shown in the figure the general increase in carbonate content has resulted in higher UCS. Lee and Kim [95] used high urea and calcium concentration to induce higher carbonate precipitation. While Zhao et al. [87] utilized batch reactors to induce carbonate precipitation in one cycle.

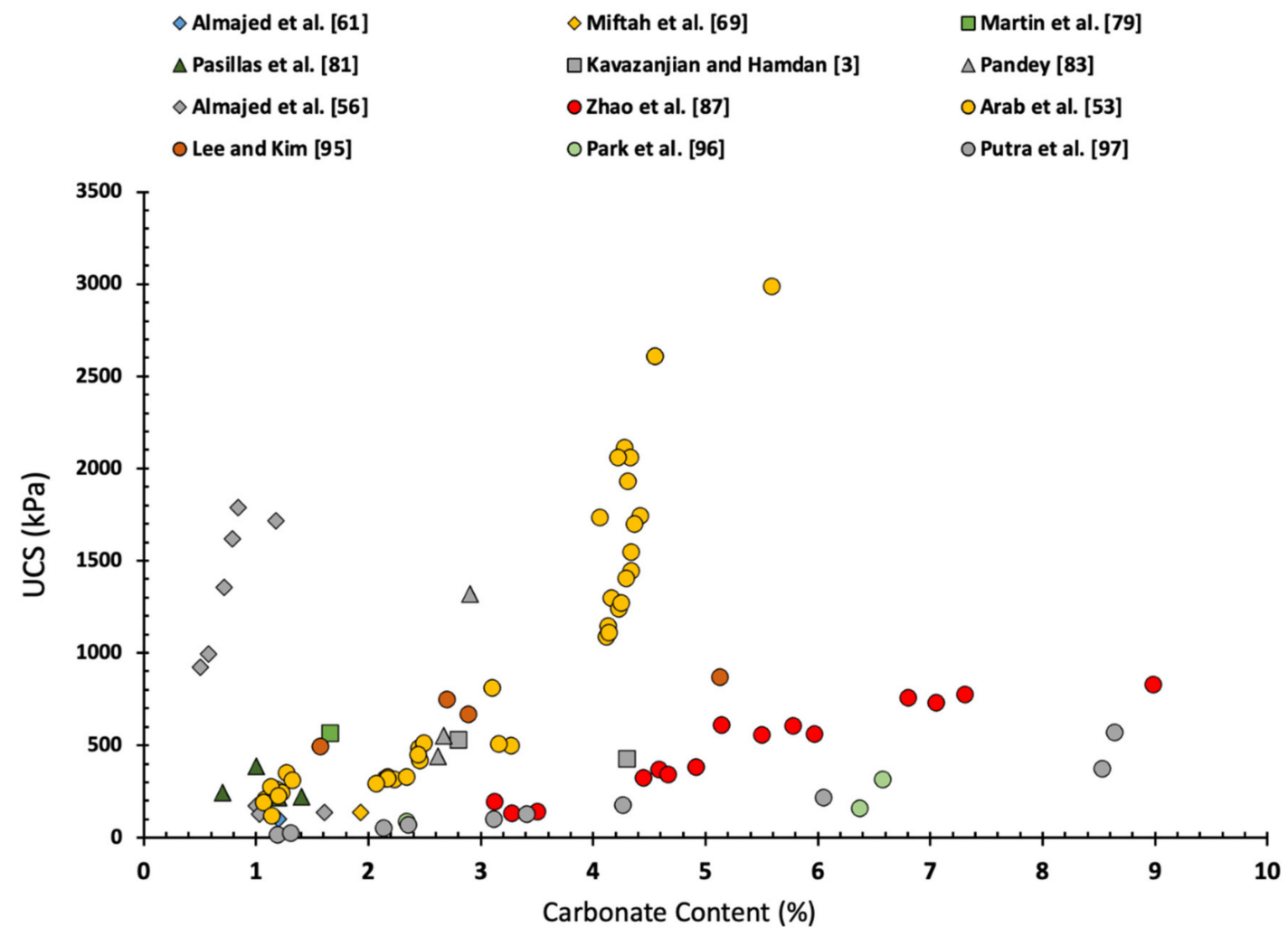

(a)

Figure 13. Cont. 


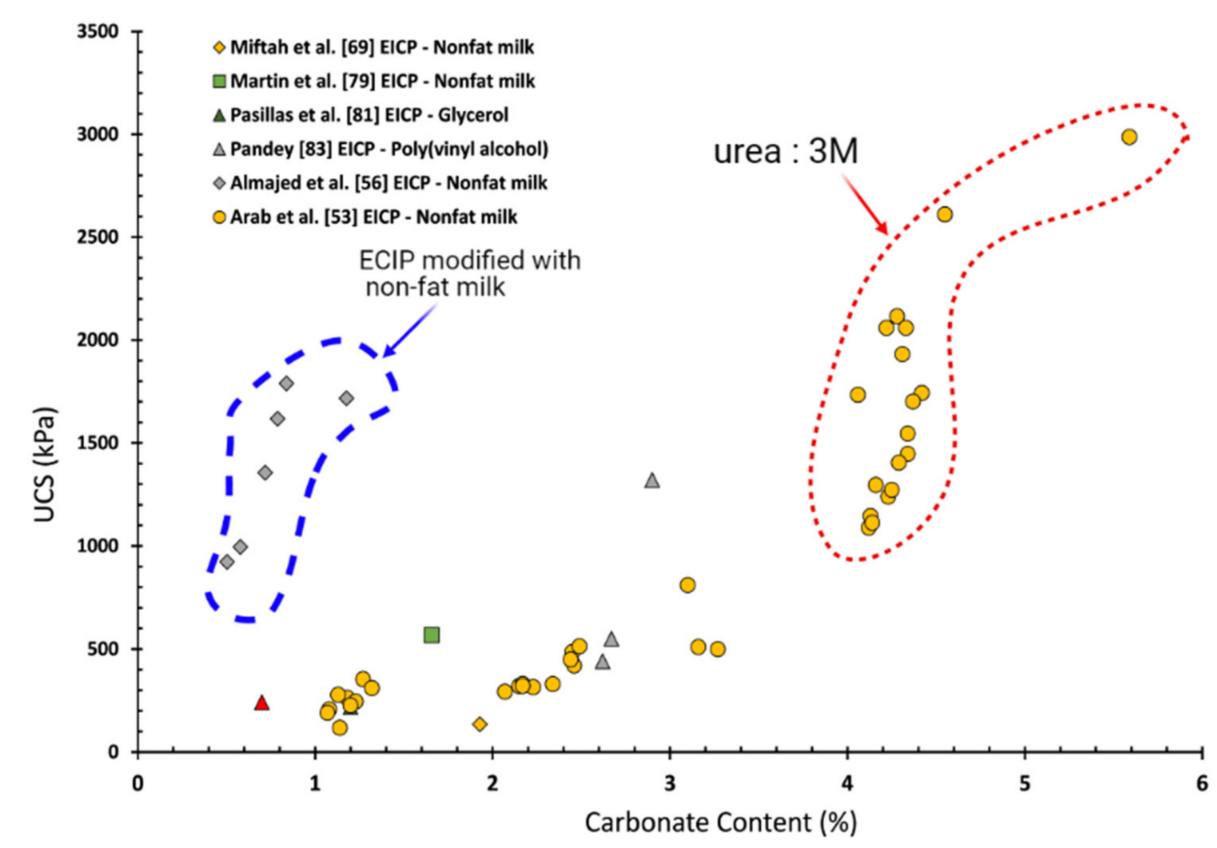

(b)

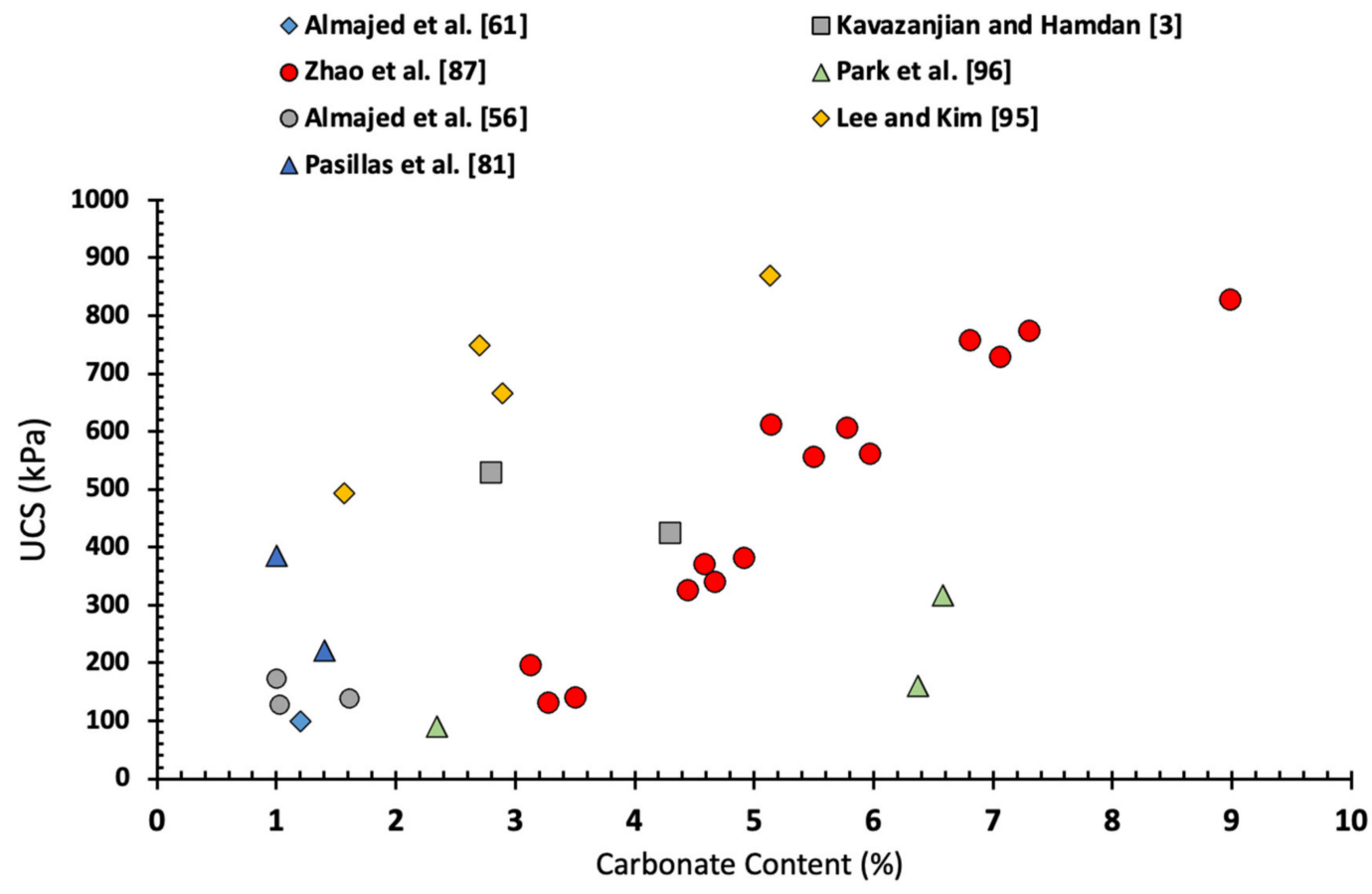

(c)

Figure 13. Effect of carbonate content on the UCS of EICP treated soils using one cycle of EICP cementing solution (a) all data for one cycle treatment; (b) modified EICP cementing solution, and (c) non-modified EICP cementing solution. Data adopted from several studies [3,51,53,56,61,69,79,81,83,87,95-97].

Finally, other researchers have explored the use of different additives to enhance the compressive strength of EICP-treated soil. Almajed [44] reported a 600\% increase in the UCS values obtained by adding $1.1 \%(w / w)$ of xanthan gum biopolymer to the soil. This significant increase in treated soil strength was attributed to the presence of the xanthan gum, which increased the bonding between soil particles. However, it should be noted that the treated sample in this study was left to dry for one month due to high water retention of the xanthan gum. 
Arab et al. [34] showed up to a $400 \%$ increase in soil compressive strength using sodium alginate biopolymer along with EICP. The use of fibres along with EICP to enhance EICP treated soil UCS was investigated [100]. The authors have utilized sisal fibre with EICP to treat Ottawa (20-30) silica sand, and the results on the UCS showed an optimal fibre ratio and fibre size of $0.3 \%(w / w)$ and $10 \mathrm{~mm}$, respectively. The maximum strength of EICP-treated sand with the optimal amount of fibres was four times greater than the samples treated with EICP alone without fibres.

\subsubsection{Triaxial Shear Test}

The triaxial shear test is a reliable method to determine the shear strength parameters for soils in general. Hamdan [58] tested both Ottawa (20-30) sand and Ottawa (F-60) silica sand treated with EICP using a triaxial test under drained conditions. Multiple cycles of EICP soil treatment were used with a one-week interval between the cycles. The triaxial testing program was conducted at a confining pressure of $60 \mathrm{kPa}$. The p-q plot failure envelopes for Ottawa (20-30) treated silica sand showed a significant increase in drained soil strength up to $100 \mathrm{kPa}$ at $2 \%$ calcite precipitation, with a relative density of $60 \%$. On the other hand, the p-q plot failure envelope of Ottawa (F-60) treated silica sand showed an increase in treated soil drained shear strength of up to $125 \mathrm{kPa}$ at $1.6 \%$ of calcite precipitation with 35\% relative density. Almajed [44] conducted an undrained triaxial test on EICP-treated Ottawa (20-30) sand samples at three confining pressures: $50 \mathrm{kPa}$, $100 \mathrm{kPa}$, and $150 \mathrm{kPa}$. When tested at $50 \mathrm{kPa}$, the test yielded a tensile failure pattern, whereas, for $100 \mathrm{kPa}$ and $150 \mathrm{kPa}$, a shear failure was observed. In this testing program, the effective friction angle $\left(\phi^{\prime}\right)$ and effective stress cohesion $(c)$ were calculated as $34.6^{\circ}$ and $332.9 \mathrm{kPa}$, respectively for EICP treated soil compared to $\phi^{\prime}=29^{\circ}$ and $c^{\prime}=0$ for untreated soil as summarized in Table 2. Song et al. [101] reported an increase in treated soil cohesion combined with a reduction in treated soil friction angle as a result of the increase in the induced carbonate content. The maximum shear stiffness achieved for EICP treated soil at $150 \mathrm{kPa}$ confining pressure was $1012 \mathrm{kPa}$ compared to $790 \mathrm{kPa}$ for the untreated soil at the same confining pressure.

Gao et al. [48] conducted triaxial consolidated undrained (CU) tests on both EICPtreated and untreated silty sand soil treated at different levels using three levels of confining pressure $(100 \mathrm{kPa}, 150 \mathrm{kPa}$, and $200 \mathrm{kPa})$. The results from his testing program are summarized in $(p-q)$ space in Figure 14. As shown in Figure 14a, as the carbonate precipitation increases both initial stiffnesses at low strain and $(q)$, which treated specimens can endure before yielding, significantly increase. Figure 14 b shows the triaxial test results in a (p-q) space with the failure envelop slope $k_{f}$ for untreated soil and $k_{f}^{*}$ for EICP treated soil at the peak $q_{p}$. As shown in the figure, when the effective stress path first reaches failure envelope $\left(k_{f}^{*}\right)$, breakage of calcite cementation at particle-particle contacts initiates. As the carbonate bonds continue to break the shear strength of the treated soil starts to degrade until it completely fails. While untreated soil exhibited monotonic failure with positive pore pressure buildup due to undrained conditions. The EICP treated soils have exhibited positive pore water pressure development as well however as the cementation pressure increases specimens start to develop dilative response with reduction in pore water pressure development. As bonds continue to break the shear resistance continues to decrease until the soil has completely failed, and the benefit of cementation is lost.

During shearing, the EICP-treated specimen reached a peak strength that degrades with the increase in the axial strain to a residual (q) compared to the untreated specimen that generates no initial peak strength and the strength gradually increases to failure as the stress path reaches the failure envelop $k_{f}$ (Figure 14a). It is important to note here that the failure envelope $\left(k_{f}\right)$ is shifted due to carbonate precipitation to $k_{f}^{*}$ having almost the same angle $(\alpha)$ of $21^{\circ}$ with an increase of the intercept $(a)$ to $38.43 \mathrm{kPa}$. 


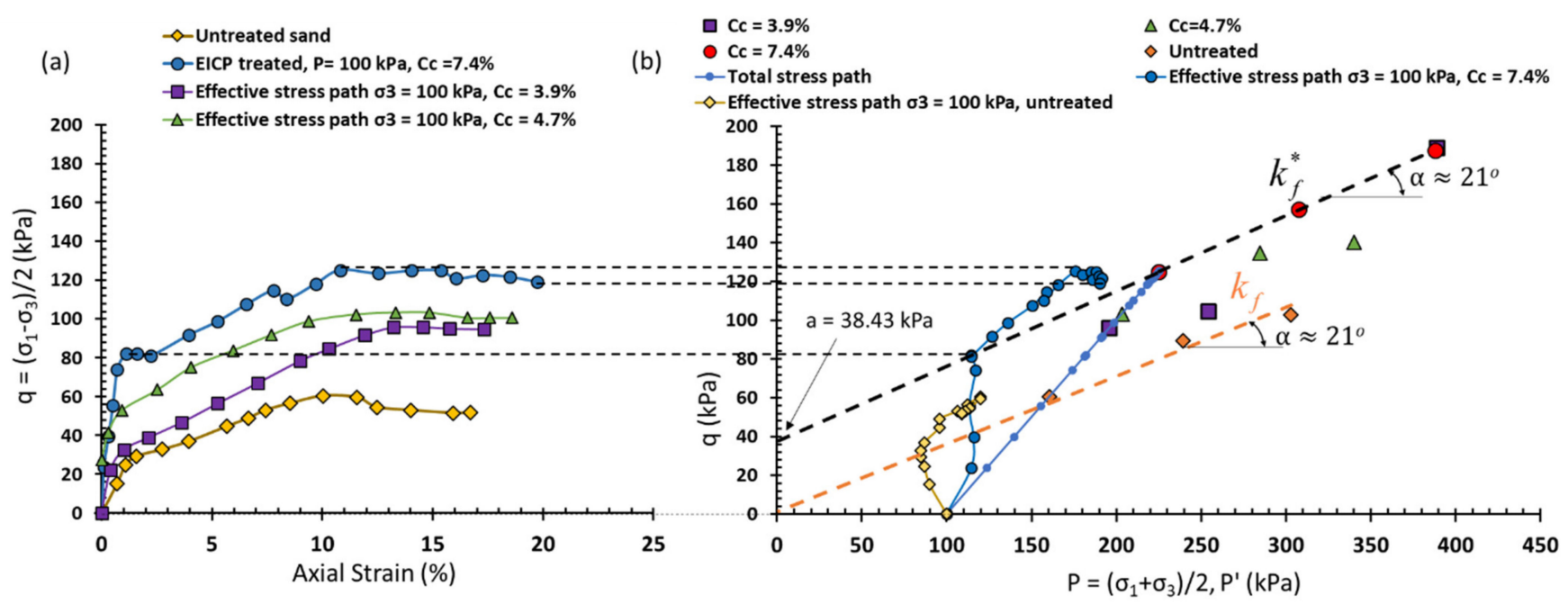

Figure 14. Experimental results for the CU triaxial response of untreated and EICP-treated specimens (data adopted from Gao et al. [48]). (a) q versus axial strain, (b) triaxial test results in a (p-q) space.

Table 2. Values for the shear strength parameters based on triaxial testing.

\begin{tabular}{ccccc}
\hline Study & $\begin{array}{c}\text { Carbonate } \\
\text { Content Range }\end{array}$ & $\begin{array}{c}\text { Confining } \\
\text { Pressure Range }\end{array}$ & $\mathbf{C}^{\prime}$ & $\boldsymbol{\Phi}^{\prime}$ \\
\hline Almajed [44] & $0.7-1.2 \%$ & $50-150 \mathrm{kPa}$ & $332.9 \mathrm{kPa}$ & $34.6^{\circ}$ \\
\hline Song et al. [101] & $1-2.2 \%$ & $50-150 \mathrm{kPa}$ & $176.1 \mathrm{kPa}$ & $28.8^{\circ}$ \\
\hline Gao et al. [48] & $3.9-7.4 \%$ & $100-200 \mathrm{kPa}$ & $42-40 \mathrm{kPa}$. & $23-19.3^{\circ}$ \\
\hline
\end{tabular}

Simatupang and Okamura [33] conducted a study to investigate the effect of the degree of saturation on the behavior of EICP-treated sand during the precipitation process using a series of undrained cyclic triaxial tests. In their study, the bio-cemented sand specimens have shown significant liquefaction resistance with a reduction in the excess pore water pressure during the cyclic loading. In this study, it was found that the liquefaction resistance of EICP treated soils is highly stress-dependent. This was manifested with a reduction in liquefaction resistance as the confining pressure increased.

\subsubsection{Direct Shear Test}

Aishwarya \& Christy [102] examined the effect of EICP treatment on the shear strength of sandy soils using a direct shear test. They found that EICP soil treatment had doubled the shear strength of untreated soil at a normal stress of $50 \mathrm{kPa}$. Interestingly, the increase in carbonate precipitation beyond a specific threshold has led to a decrease in shear strength, which was attributed to unstable carbonate within the soil pores that are not contributing to bridging soil particles together.

Moreover, Putra et al. [103] utilized a direct shear test to evaluate soil treated with modified EICP using magnesium sulfate. A cohesion of $53 \mathrm{kPa}$ was achieved at $4.1 \%$ precipitation with minimum effect on friction angle. The friction angle reported was about $19^{\circ}$ after treatment compared to $20^{\circ}$ for untreated sand.

\subsubsection{Splitting Tensile Strength (STS) and Flexural Strength}

Few studies have studied the tensile and flexural strength of soils treated with EICP solution. Arab et al. [34] studied the flexural strength of EICP treated soil beams using a three-point flexural test. The study was conducted using three EICP cementing solutions with three different concentrations of urea with a constant $\mathrm{CaCL}_{2}$ to urea ratio. The flexural strength increased with the increase in carbonate content. Ahenkorah et al. [92] studied the STS of EICP treated soils using multiple cycles of equimolar $(0.50 \mathrm{M})$ urea, calcium chloride 
$(\mathrm{CaCl} 2)$. The results show an improvement in STS as the carbonate content increased (Figure 15).

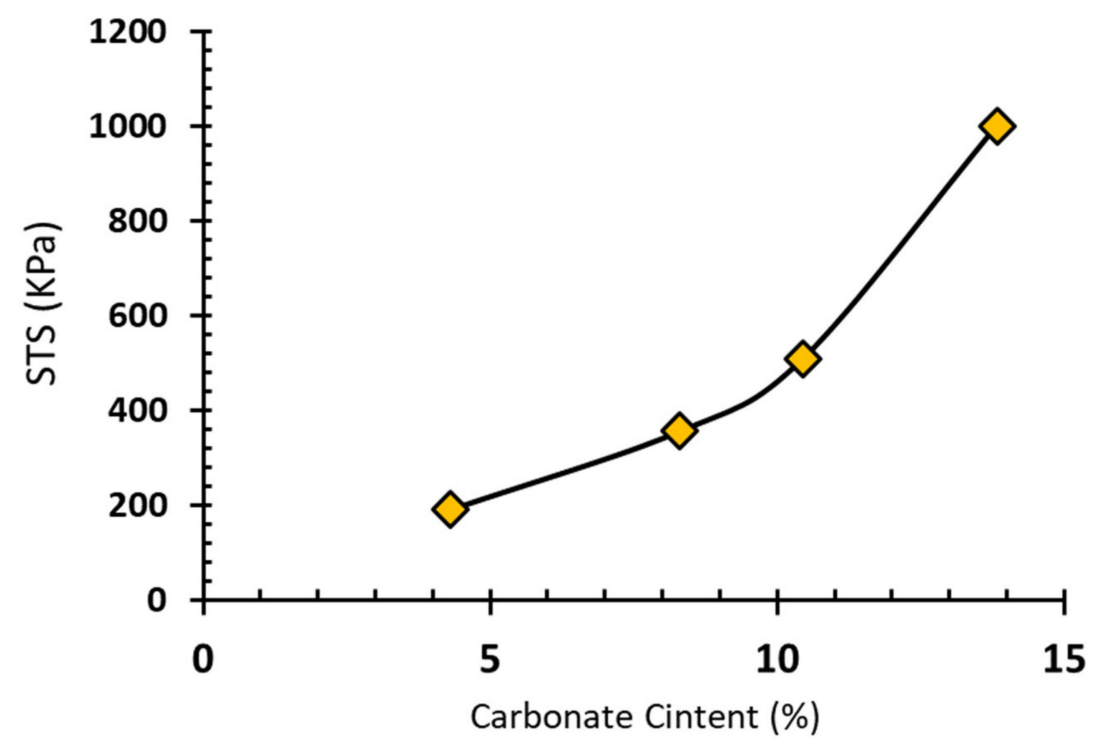

Figure 15. Splitting tensile strength (STS) versus carbonate content (data adapted from Ahenkorah et al. [92]).

\subsubsection{Shear Wave Velocity}

Shear wave velocity, $\mathrm{V}_{\mathrm{s}}$, is a soil mechanical property used as an index of both biotreated soil stiffness and strength $[2,11,12,97-105]$. It can be measured by non-destructive techniques such as bender element and resonant column, which enable continuous measurement of the development in shear modulus throughout the soil treatment process. Song et al. [2] measured the shear wave velocity and electrical conductivity of EICP-treated sand to assess the development of shear stiffness with time during the curing period. The shear wave velocity was measured using two anchored bender elements for three specimens, each with different urease concentration while maintaining the equimolar concentration of urea and calcium chloride at $1 \mathrm{M}$. For the three tested specimens, the shear wave velocity tended to increase during the precipitation of the calcium carbonate and started to converge to the maximum value when the precipitation was completed. It was concluded that the increase in urease concentration increases both the shear wave velocity and the rate of shear wave velocity gain (R) (Figure 16). Obeidy et al. [105] used a piezoceramic bender element to measure the shear wave velocity of EICP-treated sand and found that the shear wave velocity has increased from $80 \mathrm{~m} / \mathrm{s}$ for untreated soil to $120 \mathrm{~m} / \mathrm{s}$ for treated soil after only one cycle of treatment injection.

Figure 16 shows clearly the effect of enzyme kinetics on the development of soil shear wave velocity in EICP treated soils. As shown earlier in Figure 7, increasing the enzyme concentration increases the rate of hydrolysis and this may explain the increase in shear wave velocity gain rate $(R)$. 


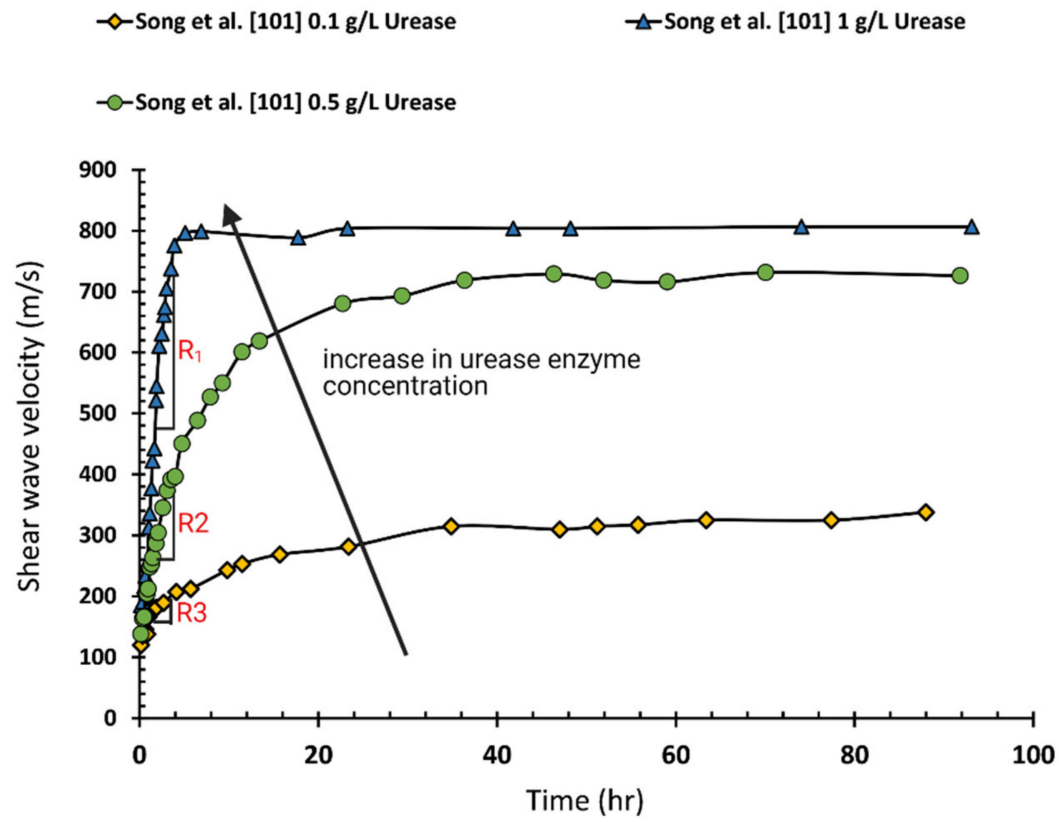

Figure 16. Shear wave velocity versus time for different urease enzyme concentrations data from (Song et al. [101]).

\section{Main Factors Affect EICP Treated Soil Properties \\ 6.1. Effect of Soil Particle Shape and Particle Size Distribution}

The bio-cemented soils and granular soils behaviour, in general, is dependent on the soil relative density [61,106,107], particle shape [108], and particle size distribution [104,105]. This is attributed to the change in the voids volume and the number and the distribution of contact points within the soil matrix. Almajed [44] treated two types of soil (Ottawa sand 20-30 and F 60 sand) using the same recipe of EICP solution. The results showed higher strength and better carbonate distribution for treated Ottawa sand (20-30) (coarse sand) compared to (F-60) sand (finer sand). Rounded particles seem to support the carbonate precipitation to adhere to the contact point and this leads to a slight increase in carbonate content [108-110]. However, the effect of particle shape on the compressive strength of bio-cemented soils is debatable since untreated sand soils with angular particles would have higher shear strength parameters compared to soils with rounded particles.

To show the significance of the soil particle shape, morphology, and chemical composition, Krishnan et al. [111,112] investigated the same silica soil with the same gradation (Ottawa sand 20-30) but from three different sources, and the results showed that the strength varied over a wide range. These results emphasize the importance of the particle shapes, morphology and biochemical properties of the sand on the mechanical performance of EICP treated sands.

\subsection{Effect of Soil Type}

Most EICP studies have focused on clean sands with no fines. Few studies reported the successful application of EICP in silty and clayey soils with fine content of more than $40 \%[48,70]$. Chandra and Ravi [70] found that EICP was not effective in treating silty soils due to its low $\mathrm{pH}$ value (measured to be 5.0). Low $\mathrm{pH}$ creates an acidic environment that negatively affects the hydrolysis of urea and precipitates less calcite. In another study by Oliveira et al. [113], silty soil showed a significant improvement in the EICP precipitation ratio; however, the silty soil in this study had a $\mathrm{pH}$ value of 7.75. Oliveira et al. [113] further found that the initial $\mathrm{pH}$ of treated soil is indicative of the treatment efficiency; besides the treatment was reported to be ineffective for soils with low $\mathrm{pH}$ values such as organic clays. Calcium carbonate precipitation was found to decrease the stiffness and strength of organic soil by almost 50\%. Oliveira et al. [113] hypothesized that organic matter formed a 
coating on the soil particles, which hindered bonding between calcium carbonate crystals and soil particles.

Zango et al. [114] investigated the strength of EICP treated residual clay soil typically used as clay liner using several EICP cementation solutions at different moulding water contents. The UCS of EICP treated clay was reported to increase with increment in the molarity of urea-CaCl2 solution. The highest UCS reported was $643.5 \mathrm{kPa}$ using $1.00 \mathrm{M}$ cementation solution prepared dry of optimum moisture content.

\subsection{Nucleation Sites for Carbonate Precipitation}

Many factors are involved in the amount and distribution of calcium carbonate minerals in the soil pores resulting from urea hydrolysis, such as the application method, enzyme activity, soil degree of compaction, and soil type. Bio-crystallization of a carbonate crystal during the hydrolysis process is a two-step process, where the nucleation of a crystal is followed by crystal growth derived by the difference in chemical potentials of the liquid and the solid crystal [115]. In the MICP treatment, in addition to the bacteria metabolic reactions that catalyse the hydrolysis of urea, it is believed that bacteria catalyse the nucleation of calcium carbonate by reducing the required activation energy barrier [116]. Microbial cell surfaces can bind $\mathrm{Ca}^{2+}$ ions due to their net negative charge [117] and this helps in forming effective bridges between the soil contact points provided by the microorganisms. However, EICP lacks nucleation sites, which allows the solute molecules to diffuse across their surface lattice instead of moving randomly around. The absence of these nucleation sites may adversely affect the carbonate precipitation distribution in the soil pores and, as a result, make the carbonate precipitation occur randomly within the soil matrix. Zehner et al. [115] showed that sand grains act as nucleation sites while observing calcite nucleation and growth in real-time via confocal laser scanning microscopy.

Almajed et al. [61] proposed using calcite seeds to improve the nucleation sites, allowing the precipitate molecules to diffuse across their surfaces. Almajed et al. [61] further examined samples treated with calcite seeds through SEM and showed that seeded solution had densely aggregated rhombohedral calcite crystals compared to the disordered morphology of the precipitates from the unseeded solution. Moreover, Zehner et al. [115] showed improvement in crystal nucleation and growth in the presence of calcite seeds.

Several researchers have proposed using non-fat powder milk as an enzyme stabilizer $[28,29,56,105]$. Almajed et al. [56] hypothesized that the non-fat powder milk may also catalyse the nucleation of calcite crystals that helps in improving carbonate precipitation in EICP treatment. As shown earlier in Figure 13b, several researchers reported that adding non-fat powder milk to the EICP solution significantly increased the compressive strength of EICP-treated soil at a much lower carbonate content. They attributed this increase partially to the nucleation points formed by the non-fat milk protein. Khodadadi et al. [45] studied the effect of specific urease activity (U) defined as urease activity by the total amount of protein ( $\mathrm{U} / \mathrm{mg}$ of protein). The specific activity can be considered as an index of the urease purity (the higher the number the higher the urease enzyme purity). Interestingly, they found that the UCS of bio-cemented sands using crude extraction with low purity was higher than those treated with high purity commercial enzymes (i.e., high specific activity) at the same conditions as shown in Figure 17. These results may suggest that organic impurities (such as proteins) in the bio-cementation solution may enhance the effectiveness of EICP by introducing nucleation sites for the carbonate crystals and reducing the energy barrier necessary for nucleation [115]. 
$\diamond$ High specific activity (300-800 U/mg protein)

$\Delta$ Low specific activity $(20-30 \mathrm{U} / \mathrm{mg}$ protein)

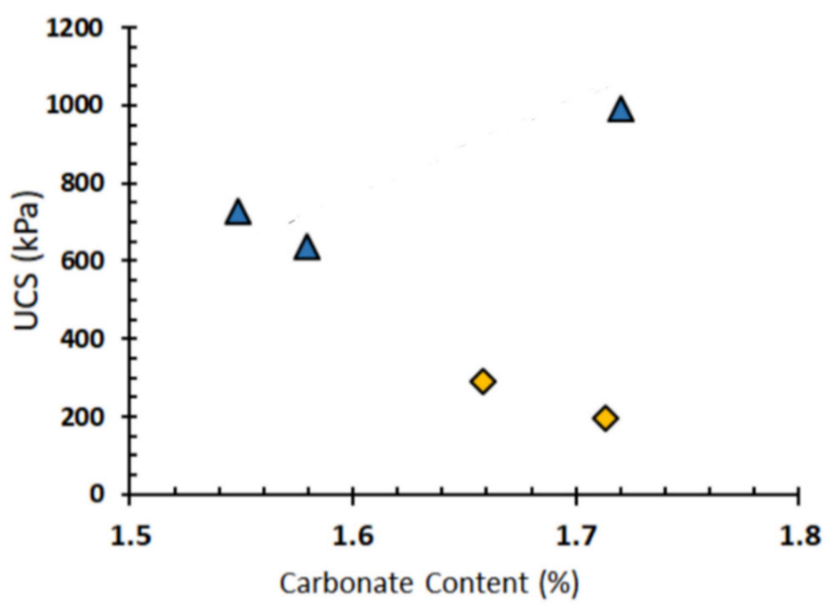

Figure 17. The effect of urease enzyme-specific activity [U/mg protein) on EICP treated sand UCS (data adopted from Khodadadi et al. [45]).

\subsection{Carbonate Crystals Morphology}

The microstructure of EICP-treated soil can be assessed visually using SEM images by observing morphology, shape, and the location of the carbonate precipitation within the soil matrix. This enables the possible correlation between the carbonate crystals morphology and the performance of EICP-treated soil. As mentioned previously, some non-active calcium carbonate particles just precipitate within the soil pores and do not contribute effectively to the treated soil strength. The carbonate crystals that enhance the strength of soil dramatically are those that form effective bridges between the soil particles. Song et al. [2] conducted a study to examine the effect of precipitation microstructure on the mechanical properties of treated soil and the morphology of calcium carbonate structure. They concluded that not only the amount of carbonate but also the location of the carbonate has a significant effect on treated soil mechanical behaviour (Figure 18). Almajed et al. [61] studied the morphology of carbonate precipitation for soils that contain calcite using SEM images. They concluded that small size rhombohedral calcite crystals are more likely in EICP treated soils that already have calcite. Moreover, they concluded that disturbance in calcite crystal formation is expected in the presence of inhibiting matter such as magnesium ions and organic compounds. Martin et al. [118] evaluated the effect of the carbonate crystals size and shape on the mechanical performance of EICP treated soils. They concluded that soils that attained higher UCS had shown calcite crystals that are agglomerated at the soil inter-particle contact locations. This improvement in crystals morphology was attributed to the use of not-fat milk in the EICP cementing solution. Zehner et al. [115] used microscope sample cell to study precipitation processes in EICP in real time in the presence of calcite seeds and sand grains. The precipitated crystals was further characterized utilizing Raman microspectroscopy and SEM. In their study dissolved chalk solution (DCS) was used as a source of calcium, it was observed that mainly calcite crystals were formed. Moreover, it was found that multiple cycles increased the contact area between aggregates and sand grains promoting effective bridges between the sand grains 

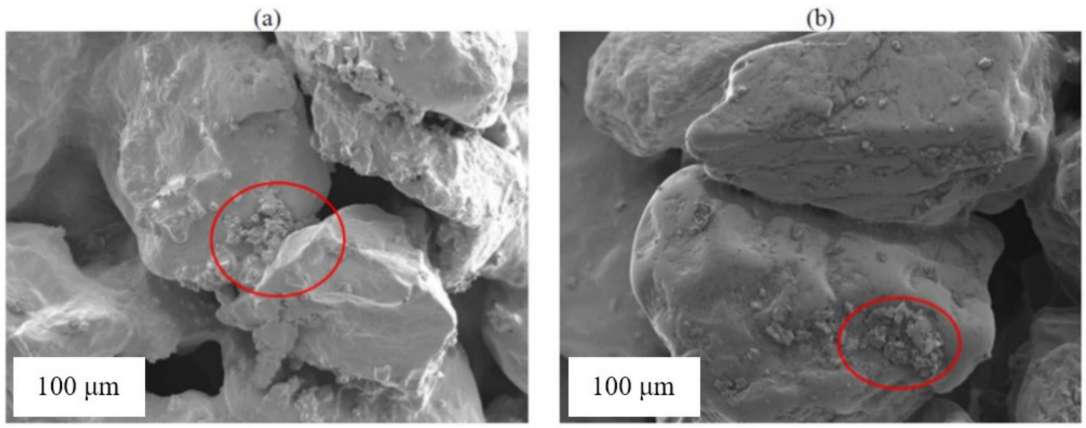

Figure 18. SEM images for two urease concentrations: (a) $0.5 \mathrm{~g} / \mathrm{L}$; and (b) $0.1 \mathrm{~g} / \mathrm{L}$ [2].

\section{Comparison between EICP and MICP}

EICP and MICP are two faces of the same coin since they both result in the precipitation of calcium carbonate via urea hydrolysis. On the contrary, these methods are different when it comes to the crystallization of $\mathrm{CaCO}_{3}$ and the mechanism of precipitation. In MICP, bacteria such as Bacillus pasteurii or Sporosarcina pasteurii are used as a source of urease compared to urease enzyme derived from a plant source in EICP or bacterial source in bacterial enzyme-induced carbonate precipitation (BEICP). Comparing MICP and EICP at the microscale can be a complicated process; the behaviour of free enzyme and living bacteria can vary depending on the soil type, cementing solution concentration, and enzyme source. However, a comparison in terms of performance and efficiency obtained from each method is achievable through routine shear and compressive strength testing.

Nafisi et al. [119] compared the macroscale and microscale behaviour of MICP- and EICP-treated soils through conducting triaxial testing, shear wave velocity, and SEM. They observed that EICP-treated soil needs less calcium carbonate precipitation to achieve the same shear wave velocity obtained from MICP-treated soil. Moreover, Nafisi et al. [119] compared the shear responses under drained conditions for EICP- and MICP-treated specimens at the same level of shear wave velocity. It was found that MICP specimens result in higher shear strength and larger dilative strain; however, MICP needed a higher number of injections to achieve the same shear wave velocity obtained from EICP samples. In order to induce enough carbonate precipitation in both bio-cementation techniques, several researchers have used cycles of treatment. In MICP, several strategies have been proposed to achieve higher carbonate precipitation $[4,14,83,120]$. These strategies include several cycles of two-phase injection of the microbial culture, followed by injection of the cementing solution containing the urea, calcium chloride, and nutrition needed for the microbial activity. However, few researchers have proposed techniques to induce carbonate after only one cycle of treatment. Cui et al. [121,122] proposed the use of (one-phase-low$\mathrm{pH}$ method) in which EICP solution consisting of urea and calcium chloride with urease solution of $\mathrm{pH}=6.5$, is injected into the soil for one phase treatment of sand. Arab et al. [53] and Lee and Kim [95] proposed the use of high concentration EICP solution (up to $3 \mathrm{M}$ urea concentration) to induce enough carbonate precipitation after one cycle of treatment.

Zhao et al. [87] utilized a batch reactor to induce carbonate precipitation in one cycle using both MICP and EICP. They found that using microbially produced urease is superior to using free urease enzymes when it comes to the enhancement of soil mechanical properties. It was found that under the same enzyme activity for both methods, MICPtreated soil had much better performance than EICP-treated soil; MICP-treated samples had an unconfined compressive strength of 1.76-2.04 MPa, while EICP samples had only 0.33-0.43 MPa.

To understand the effect of carbonate content on the UCS for both techniques (i.e., MICP and EICP), the results of carbonate content against UCS results were compiled from several studies in the literature and summarized in Figure 19. Figure 19a shows a comparison of EICP treated soils versus MICP treated soils after only one cycle of treat- 
ment. It can be concluded that higher UCS results were achieved in EICP-treated soil at lower carbonate precipitation compared to MICP-treated soil.

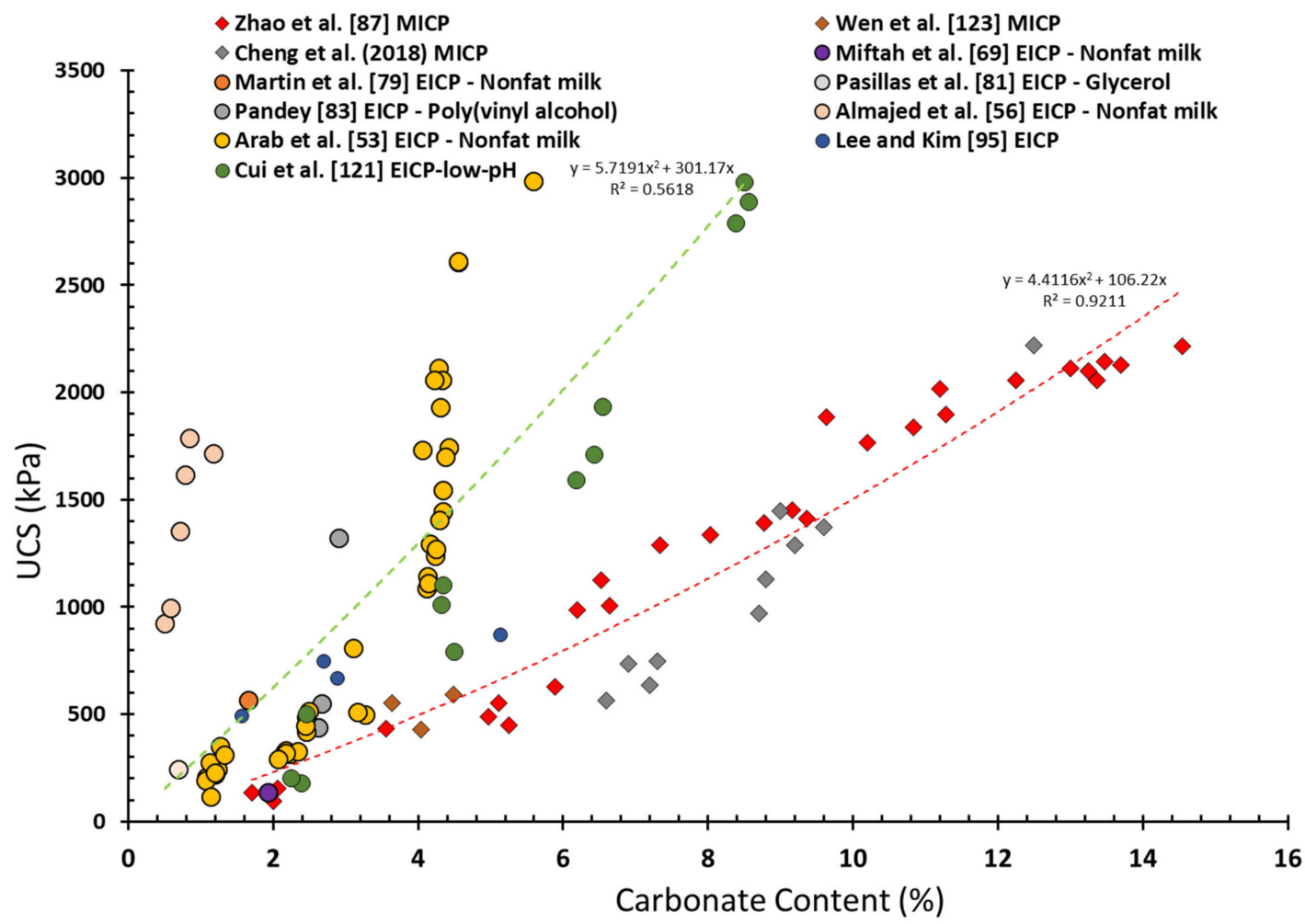

(a)

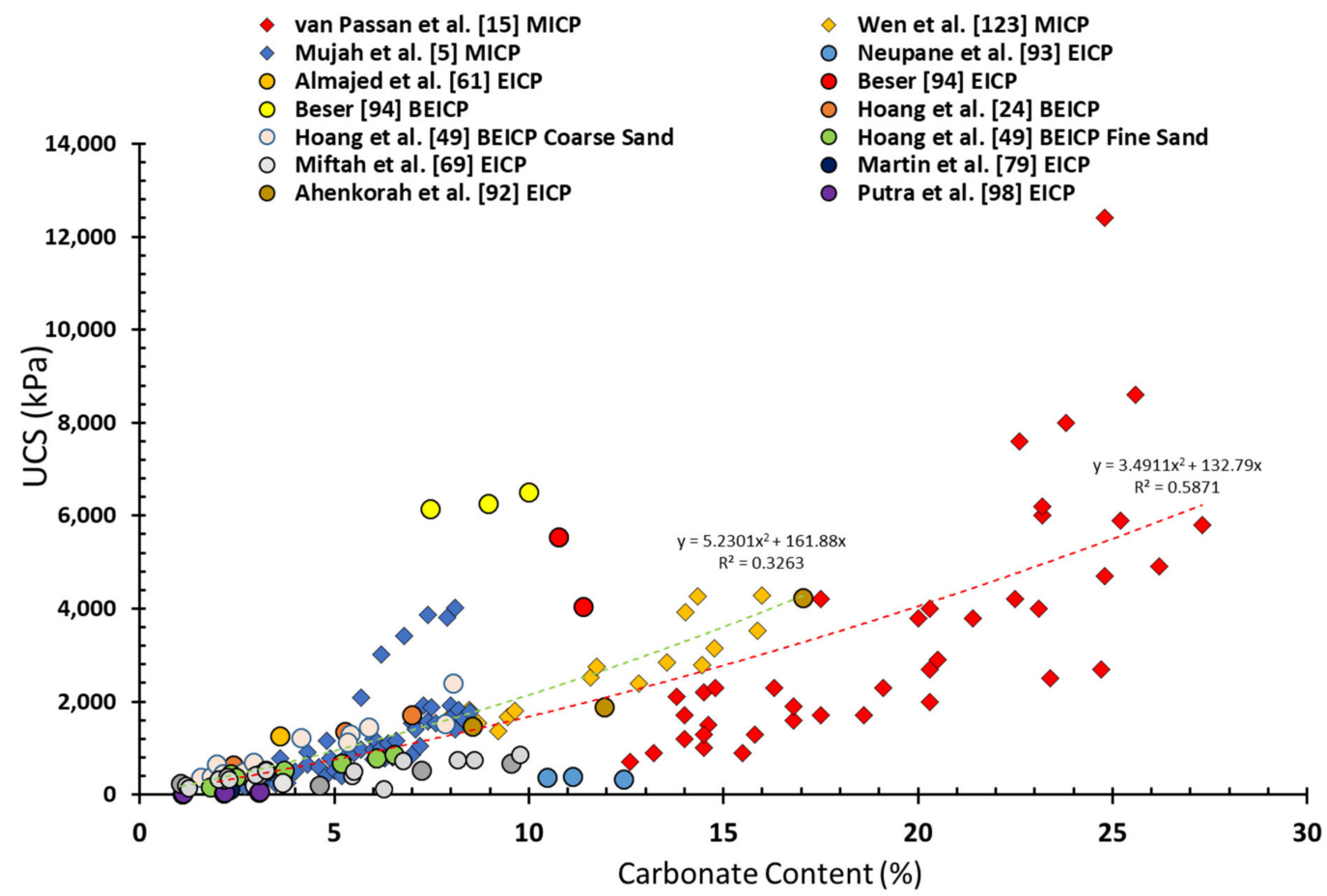

(b)

Figure 19. Comparison of UCS for both MICP and EICP treated specimens versus carbonate content (a) one treatment cycle; (b) multiple treatment cycles (results collected from different studies, MICP-diamond and EICP-circle)data adopted from several studies $[5,15,24,49,61,69,79,92-94,98,123]$. 
Figure 19b shows the comparison for the case of multiple treatment cycles. It can be seen that, in general, higher carbonate content was achievable in the case of MICP, which resulted in higher UCS results for MICP-treated soils. To achieve such higher carbonate contents, a higher number of injections are required in the case of MICP-treated soil. The above comparison between EICP and MICP demonstrated that EICP is advantageous to MICP in terms of efficiency in the case of one cycle of treatment and higher compressive strength is achievable at lower carbonate content. However, higher carbonate content was achieved using multiple treatment cycles with higher UCS as well for the case of MICP. Similar conclusions were reached by Ahenkorah et al. [92] by comparing EICP to MICP treatment at the same conditions. In their study, a higher increase in UCS and carbonate content was achieved for soils treated with MICP compared to EICP after the same number of treatment cycles. However, higher uniformity of carbonate precipitation over the length of the treated soil columns was achieved in the case of EICP treated specimens with higher splitting tensile strength compared to MICP treated specimens at the same carbonate content.

\section{Envisioned Applications of Soil Bio-Cementation via EICP}

Even though the treatment of EICP is not yet commercialized and is still under development, many envisioned applications can be suitable for this promising technique in the future, serving as a sustainable solution for several engineering applications. This includes fugitive dust mitigation [27-32], surface water erosion control [29], creation of subsurface barrier excavation stabilization, soil nailing [78], liquefaction mitigation [33,46], and foundation support, among others $[44,58]$. Besides, EICP has been recently investigated to heal cracks in cement mortars [36] and combined with cement to improve cement-treated soil behavior [111]. Moreover, EICP can mitigate earthquake-induced soil liquefaction, improve soil slope stability, and immobilization of divalent cation contaminants [108]. More recently, in a trial to scale-up the EICP for field applications, Martin et al. [37,79] utilized a tube-a-manchette injection system to inject EICP cementing solution in the field. This demonstrates the ability of the EICP to be used for soil improvement in the field using conventional installation methods. Finally, Nething et al. [124] successfully implemented biomineralization in 3D printing a rigid and stable bio-cemented sand structure using urease active calcium carbonate powder.

\subsection{Advantages of EICP for Soil Improvement}

- $\quad$ EICP can promote sustainability and provide a product that has a less harmful impact on the environment than other conventional methods. When compared to Ordinary Portland Cement (OPC), carbonate cementation can replace OPC for a variety of ground improvement applications while reducing carbon dioxide emissions. EICP is likely a less energy-extensive solution than OPC.

- Urease used in EICP is a powder-like material that is soluble in water with a size of around $12 \mathrm{~nm}$ per subunit, which facilitates penetration into fine-grained soils [19].

- Using a free urease enzyme to hydrolyse urea eliminates some of the complications and restrictions related to the microbial technique. Some of these restrictions include microbial cell transport in soil, oxygen availability for deep soil treatment (for biostimulation), the need to provide nutrients for bacterial activity, and interaction with other microorganisms. These restrictions can be easily avoided when employing a free urease enzyme for the process of hydrolysis $[19,122]$.

- Another potential benefit of EICP is that it can be transported to the site as a dry powder without any strict measures regarding temperature or handling. However, in the case of MICP, If the bacteria are grown off-site, they would have to be transported as a liquid or slurry (probably refrigerated), which would increase the cost. Even if ureolytic bacteria are cultivated on-site, custom-built tools and reactors have to be utilized [125]. 
- $\quad$ EICP is a flexible treatment that can be adjusted for many engineering applications, as mentioned earlier. A slight change in the mixture and concentration of the solution can give a different response in terms of shear strength, permeability, and shear wave velocity [121].

\subsection{Challenges of EICP for Soil Bio-Cementation}

Although EICP is a promising solution for many engineering applications, the treatment method is not simple, and several issues need to be addressed by the research community to further enhance the EICP field application and maximize its benefits, including:

- Environmental concerns regarding the contamination of groundwater caused by the production of ammonium chloride $\left(\mathrm{NH}_{4} \mathrm{Cl}\right)$ as a by-product of the EICP process. Ammonium is potentially harmful and has a strong odour and can endanger the water supplies $[29,126]$. Furthermore, the choice to flush the ammonium from the soil is likely to be uneconomical $[19,31]$. To solve this problem, it was suggested to treat the cementation solution from ammonia-rich effluent before discharge and then back-feed the ammonia as a fertilizer to the surrounding plants [17]. Zehner et al. [115] successfully utilized crushed industrial quality limestone as a source of calcium instead of $\mathrm{CaCl}_{2}$. This process eliminated the production of chloride salts that may pollute water and lead to steel corrosion. However, this issue is still under investigation and considered one of the major challenges that face the wide applications of these techniques in the field.

- The distribution and homogeneity of the EICP treatment should be addressed as well as the soil compatibility and particle size. Since the EICP solution is water-based with low viscosity, it is hard to control the treated soil mass. Attempts to increase the viscosity of the treatment solution using biopolymers or copolymers could be the solution to immobilize the treatment solution and enhance its distribution along the soil matrix [81]. It is also crucial to control the rate of precipitation to improve the spatial distribution of carbonate within the soil pores [122].

- Scale-up bio-cementation for field soil grouting applications is still under investigation. Few studies have investigated the use of industrial-grade economical chemical constituents for the use in the hydrolysis process [125,127]. Recently, Khodadadi et al. [45] have shown that crude extracted urease enzyme from jack beans through a simplified process that involves few steps that can be conducted in situ. The process was used for mid-scale EICP injection in the field in demonstration of the possibility of scaling the process up [115]. However, more economical strategies need to be developed to scale up the production of EICP for grouting in field applications.

- $\quad$ Replacing bacteria with free enzymes in EICP leads to the loss of nucleation sites and potentially fastens the decay of urease activity as the enzyme may break down easier when not protected by the bacterial cell wall. However, a recent study by Almajed et al. [56] reported that adding non-fat dry milk powder provides nucleation sites for the calcium carbonate and enhances the stability of the urease, which works as an alternative to the bacterial cell wall. It is believed the protein in the milk can bind the calcium ions in the EICP solution, resulting in aggregate calcite or precipitate that acts as a nucleation site for carbonate precipitation [128]. However, the effect of the protein in the EICP cementing solution needs further investigation.

- Long term durability of EICP treated soils needs further investigation. For example, Song et al. [129] studied the effect of loading cycles on the shear wave velocity of EICP treated soils. They concluded that the stiffness of EICP-treated soils degrades when stress increases beyond debonding stresses, and this stress threshold depends mainly on the void ratio. Additionally, the post erosion behaviour of EICP treated soil in light of available literature of the behaviour of untreated gap-graded sandy soil [130]. 


\subsection{Future Research}

EICP falls in the category of bio-geotechnical engineering, which is an emerging and promising multidisciplinary field that involves earth science and microbiology ecology, structure, geotechnical, and chemical engineering. Although EICP has proven itself as a reliable method for soil treatment, it is still in its infancy and needs to be addressed in terms of maximizing the efficiency of treatment and reaching an optimum implementation that can lead to its commercial use.

Several studies have investigated the behaviour of soil treated with EICP, both at the microscale and macroscale. However, further research in terms of upscaling and implementing field-scale tests will help to identify the optimal application method and the effect of complex environmental conditions. Another aspect of field application of this technique is the understanding of the durability of EICP-treated soils when exposed to environmental conditions, which in turn will assist in understanding the durability of the treatment process and how tolerable it is to freeze-thaw, wet-dry, temperature, and humidity variations. It is critical to understand the urease production, handling, storage, and overall efficiency for in situ implementation and optimizing the performance for the required application in terms of optimum concentration of the solution and chemical environment affecting the overall process.

Enzyme activity is a major player in the whole process. It is important to advance characterizing the behaviour of the urease catalyst for more improved ways to quantify urease activity based on the enzyme protein mass, depletion rate, sorption properties, and solubility of the free urease enzymes. Moreover, the saturation level of soil may have a significant level on the precipitation distribution, which reflects the strength of EICP treated soils.

The groutability of EICP is a major concern, since the EICP cementing solution is water-based. Hydrogels, biopolymers, and copolymers have been investigated as additives to enhance the retention of the EICP cementing solution in the soil matrix, the calcite distribution, and the minimization of soil segregation and cementation medium. These aspects certainly need more work to clarify the use and benefits of EICP.

Author Contributions: Conceptualization, M.G.A., R.A. and A.A. formal analysis M.G.A., R.A., A.A. and M.A.S.; methodology, M.G.A., R.A., resources, M.G.A., R.A. and A.A.; validation, H.Y., W.Z. and M.A.S.; writing—original draft, M.G.A., R.A., A.A. and M.A.S. writing—review and editing, H.Y. and W.Z. All authors have read and agreed to the published version of the manuscript.

Funding: This research received no external funding.

Institutional Review Board Statement: Not applicable.

Informed Consent Statement: Not applicable.

Data Availability Statement: No new data were created or analyzed in this study. Data sharing is not applicable to this article.

Acknowledgments: The authors also would like to thank the Deanship of Scientific Research and RSSU at King Saud University for their technical support in proofreading the text.

Conflicts of Interest: The authors declare no conflict of interest. 


\section{Appendix A}

Table A1. Summary of Previous Research Papers on EICP.

\begin{tabular}{|c|c|c|c|c|c|c|c|}
\hline \multirow[b]{2}{*}{ Application } & \multirow[b]{2}{*}{ Reference } & \multicolumn{4}{|c|}{ EICP Cementing Solution } & \multirow[b]{2}{*}{ Soil Type } & \multirow{2}{*}{$\begin{array}{l}\text { A Measure of Soil } \\
\text { Improvement and } \\
\text { General Remarks }\end{array}$} \\
\hline & & Urea & $\mathrm{CaCl}_{2}$ & $\begin{array}{l}\text { Jack Bean } \\
\text { Urease }\end{array}$ & Additives & & \\
\hline \multirow{10}{*}{$\begin{array}{l}\text { Improve Soil } \\
\text { Compressive } \\
\text { Strength }\end{array}$} & $\begin{array}{l}\text { Yasuhara } \\
\text { et al. [26] }\end{array}$ & $\begin{array}{c}0.5 \text { and } \\
1.0 \mathrm{~mol} / \mathrm{L}\end{array}$ & $\begin{array}{c}0.5 \text { and } \\
1.0 \mathrm{~mol} / \mathrm{L}\end{array}$ & $\begin{array}{c}0.5 \text { and } \\
1.0 \mathrm{~g} / 300 \mathrm{~g} \text { of } \\
\text { sand } \\
\text { (activity not } \\
\text { reported) }\end{array}$ & - & Toyoura sand & $\begin{array}{l}\text { UCS in the range } \\
400 \mathrm{kPa} \text { to } 1.6 \mathrm{MPa}\end{array}$ \\
\hline & $\begin{array}{l}\text { Park et al. } \\
\text { [96] }\end{array}$ & $\begin{array}{c}5 / 50 \text { to } \\
25 / 50 \mathrm{~g} / \mathrm{mL}\end{array}$ & $\begin{array}{c}10 / 50 \mathrm{~g} / \mathrm{mL} \\
\text { Calcium } \\
\text { Chloride, } \\
\text { Calcium } \\
\text { Hydroxide, or } \\
\text { Calcium } \\
\text { nitrate. }\end{array}$ & $\begin{array}{l}0 \text { to } 25 \mathrm{~mL} \text { Jack } \\
\text { Bean extract }\end{array}$ & - & $\begin{array}{c}\text { Local sand } \\
\text { from Nakdong } \\
\text { River }\end{array}$ & $\begin{array}{c}\text { Achieved UCS } \\
\text { ranging from } 30 \text { to } \\
317 \mathrm{kPa}\end{array}$ \\
\hline & $\begin{array}{l}\text { Neupane } \\
\text { et al. [60] }\end{array}$ & $1 \mathrm{~mol} / \mathrm{L}$ & $1 \mathrm{~mol} / \mathrm{L}$ & $\begin{array}{c}15 \mathrm{~g} / \mathrm{L} \\
\text { At } 2970 \text { units } / \mathrm{g} \\
\text { activity }\end{array}$ & - & $\begin{array}{l}\text { Homogenous } \\
\text { silica sand } \\
\text { specimens }\end{array}$ & $\begin{array}{l}\text { UCS of around } \\
380 \mathrm{kPa}\end{array}$ \\
\hline & $\begin{array}{c}\text { Kavazanjian } \\
\text { and Hamdan } \\
{[3]}\end{array}$ & $\begin{array}{c}1.38 \mathrm{M} \text { (mix } \\
\text { and compact) } \\
1.36 \\
\text { (injection) }\end{array}$ & $\begin{array}{c}1.58 \mathrm{M} \text { (mix } \\
\text { and compact) } \\
0.765 \\
\text { (injection) }\end{array}$ & $\begin{array}{c}0.40 \mathrm{~g} / \mathrm{L} \text { at } \\
200 \mathrm{U} / \mathrm{g} \text { activity } \\
\text { (mix and } \\
\text { compact) } \\
0.44 \mathrm{~g} / \mathrm{L} \text { at } \\
26,100 \mathrm{U} / \mathrm{g} \\
\text { activity } \\
\text { (injection) }\end{array}$ & $\begin{array}{l}\text { non-fat dry } \\
\text { milk at } \\
4.0 \mathrm{~g} / \mathrm{L}\end{array}$ & $\begin{array}{l}\text { Ottawa 20/30 } \\
\text { silica sand }\end{array}$ & $\begin{array}{c}\text { UCS of } \\
529 \mathrm{kPa} \text { at } 0.8 \% \\
\text { axial strain and } \\
425 \mathrm{kPa} \text { at } 1.8 \% \text { for } \\
\text { mix and } \\
\text { compact treatment }\end{array}$ \\
\hline & $\begin{array}{l}\text { Putra et al. } \\
\text { [98] }\end{array}$ & $0.5 \mathrm{~g} / \mathrm{L}$ & $0.5 \mathrm{~g} / \mathrm{L}$ & $1 \mathrm{~g} / \mathrm{L}$ & - & Keisa sand & $\begin{array}{c}\text { Achieved UCS of } \\
60 \mathrm{kPa} \text { at } 3 \% \\
\text { carbonate } \\
\text { precipitation }\end{array}$ \\
\hline & $\begin{array}{l}\text { Carmona } \\
\text { et al. [62] }\end{array}$ & $\begin{array}{l}0.25 \text { to } \\
1.25 \mathrm{M}\end{array}$ & 0.25 to $1.25 \mathrm{M}$ & $\begin{array}{l}0.12 \mathrm{~g} / \mathrm{L} \\
(4 \mathrm{kU} / \mathrm{L})\end{array}$ & - & $\begin{array}{l}\text { Poorly graded } \\
\text { sandy soil } \\
\text { (ASTM D2487) }\end{array}$ & $\begin{array}{c}\text { UCS of } 140 \mathrm{kPa} \text { at } \\
0.25 \mathrm{M} \text { solution }\end{array}$ \\
\hline & $\begin{array}{c}\text { Zhao et al. } \\
\text { [74] }\end{array}$ & $1.5 \mathrm{M}$ & $1 \mathrm{M}$ & $\begin{array}{c}0.450 \mathrm{mg} / \mathrm{mL} \text { at } \\
\text { activity of } \\
15,000- \\
10,250,000 \\
\text { units/g) }\end{array}$ & $\begin{array}{l}1 \mathrm{~mL} / \mathrm{mL} \text { of } \\
\text { solution of } \\
\text { polyacrylate } \\
\text { gel }\end{array}$ & Ottawa F-60 & $\begin{array}{c}\text { Hydrogel } \\
\text { enhanced EICP } \\
\text { was able to } \\
\text { withstand up to } \\
4.8 \times 10^{3} 265 \mathrm{kPa}\end{array}$ \\
\hline & $\begin{array}{l}\text { Putra et al. } \\
\text { [97] }\end{array}$ & $0.5 \mathrm{~mol} / \mathrm{L}$ & $\begin{array}{c}0.25 \text { to } \\
0.5 \mathrm{~mol} / \mathrm{L} \\
\text { Calcium } \\
\text { Chloride or } \\
0 \text { to } 0.25 \mathrm{~mol} / \mathrm{L} \\
\text { Magnesium } \\
\text { Chloride }\end{array}$ & $\begin{array}{l}1 \mathrm{~g} / \mathrm{L} \text { at } \\
\text { Activity of } \\
2950 \mathrm{U} / \mathrm{g}\end{array}$ & - & Dry silica sand & $\begin{array}{c}\text { Achieved } 0.6 \mathrm{MPa} \\
\text { at } 8.3 \% \text { of } \\
\text { carbonate } \\
\text { precipitation }\end{array}$ \\
\hline & $\begin{array}{l}\text { Putra et al. } \\
\text { [99] }\end{array}$ & $\begin{array}{l}0.5 \text { and } 1 \\
\mathrm{~mol} / \mathrm{L}\end{array}$ & $\begin{array}{l}\text { Mixtures of } \\
\text { Calcium } \\
\text { Chloride, } \\
\text { Magnesium } \\
\text { Chloride and } \\
\text { Magnesium } \\
\text { Sulfate at } 0.04 \\
\text { to } 1 \mathrm{~mol} / \mathrm{L}\end{array}$ & 1 or $2 \mathrm{~g} / \mathrm{L}$ & - & Dry silica sand & $\begin{array}{c}\text { Maximum UCS of } \\
555 \mathrm{kPa} \text { was } \\
\text { achieved at } 10 \% \\
\text { carbonate } \\
\text { precipitation }\end{array}$ \\
\hline & $\begin{array}{c}\text { Oliveira et al. } \\
\text { [113] }\end{array}$ & 0.25 to $0.5 \mathrm{M}$ & 0.25 to $0.5 \mathrm{M}$ & $\begin{array}{l}4 \mathrm{kU} / \mathrm{L} \text { to } \\
8 \mathrm{kU} / \mathrm{L} \text { of } \\
\text { activity } \\
34,310 \mathrm{U} / \mathrm{g}\end{array}$ & - & $\begin{array}{l}\text { Sandy, silty, } \\
\text { and organic } \\
\text { soils }\end{array}$ & $\begin{array}{c}\text { Strength gain: } \\
\text { sandy soil }(25 \mathrm{kPa}) \text {, } \\
\text { silty soil }(250 \mathrm{kPa}), \\
\text { organic soil } \\
(50 \mathrm{kPa})\end{array}$ \\
\hline
\end{tabular}


Table A1. Cont.

\begin{tabular}{|c|c|c|c|c|c|c|c|}
\hline \multirow[b]{2}{*}{ Application } & \multirow[b]{2}{*}{ Reference } & \multicolumn{4}{|c|}{ EICP Cementing Solution } & \multirow[b]{2}{*}{ Soil Type } & \multirow{2}{*}{$\begin{array}{l}\text { A Measure of Soil } \\
\text { Improvement and } \\
\text { General Remarks }\end{array}$} \\
\hline & & Urea & $\mathrm{CaCl}_{2}$ & $\begin{array}{c}\text { Jack Bean } \\
\text { Urease }\end{array}$ & Additives & & \\
\hline & Almajed [44] & $\begin{array}{c}0.875,1.75 \\
\text { and } 2.65 \mathrm{M}\end{array}$ & $0.5,1$ and $1.5 \mathrm{M}$ & $\begin{array}{c}0.85 \mathrm{~g} / \mathrm{L} \text { at } \\
\text { activity of } \approx \\
1500-2500 \mathrm{U} / \mathrm{g}\end{array}$ & $\begin{array}{l}1.1 \% \text { xanthan } \\
\text { gum }(w / w \%) \\
\text { of sand and } \\
4.0 \mathrm{~g} / \mathrm{L} \text { of dry } \\
\text { nonfat milk }\end{array}$ & $\begin{array}{l}\text { Ottawa 20/30 } \\
\text { silica sand }\end{array}$ & $\begin{array}{l}\text { The addition of } \\
\text { xanthan gum } \\
\text { resulted in UCS of } \\
1461 \mathrm{kPa} \text { when } \\
\text { mixed with a } \\
\text { powder with } \\
\text { the soil }\end{array}$ \\
\hline & Almajed [61] & $1 \mathrm{M}$ & $0.67 \mathrm{M}$ & $\begin{array}{c}3 \mathrm{~g} / \mathrm{L} \text { at activity } \\
\text { of } 3500 \mathrm{U} / \mathrm{g} \text { ) }\end{array}$ & - & $\begin{array}{c}\text { Ottawa } 20 / 30 \\
\text { sand }\end{array}$ & $\begin{array}{l}\text { UCS of } 1268 \mathrm{kPa} \\
\text { after } 4 \text { cycles } \\
\text { of treatment }\end{array}$ \\
\hline & $\begin{array}{l}\text { Chandra \& } \\
\text { Ravi [70] }\end{array}$ & $0.5 \mathrm{~mol} / \mathrm{L}$ & $0.5 \mathrm{~mol} / \mathrm{L}$ & $\begin{array}{l}8 \mathrm{kU} / \mathrm{L} \text { at } \\
\text { activity of } \\
40,150 \mathrm{U} / \mathrm{g}\end{array}$ & - & $\begin{array}{l}\text { silty sand (SM), } \\
\text { clayey sand } \\
(\mathrm{SC}), \text { and silt } \\
(\mathrm{ML})\end{array}$ & $\begin{array}{l}\text { SM \& ML achieved } \\
\text { UCS of around } \\
\text { (200 kPa), SC } \\
\text { achieved UCS of } \\
(400 \mathrm{kPa})\end{array}$ \\
\hline & Beser [94] & $20 \mathrm{~g} / \mathrm{L}$ & $49 \mathrm{~g} / \mathrm{L}$ & $\begin{array}{c}5 \mathrm{~g} / \mathrm{L} \text { (activity } \\
\text { not reported) }\end{array}$ & - & $\begin{array}{l}2095 \text { granular } \\
\text { silica sand }\end{array}$ & $\begin{array}{l}\text { EICP achieved } 66 \% \\
\text { and } 77 \% \text { UCS of } \\
\text { the } 28 \text {-day well } \\
\text { cement and Type I } \\
\text { cement mortars }\end{array}$ \\
\hline & $\begin{array}{l}\text { Almajed } \\
\text { et al. [100] }\end{array}$ & $0.5 \mathrm{M}$ & $0.875 \mathrm{M}$ & $\begin{array}{l}0.85 \mathrm{~g} / \mathrm{L} \text { at } \\
\text { Activity of } \\
3500 \mathrm{U} / \mathrm{g}\end{array}$ & - & $\begin{array}{c}\text { Ottawa } 20 / 30 \\
\text { sand }\end{array}$ & $\begin{array}{c}\text { UCS in the range of } \\
25 \mathrm{kPa} \text { to } 296 \mathrm{kPa} \\
\text { when sisal fiber } \\
\text { was mixed } \\
\text { with soil }\end{array}$ \\
\hline & $\begin{array}{l}\text { Pasillas et al. } \\
\text { [81] }\end{array}$ & $1 \mathrm{M}$ & $0.67 \mathrm{M}$ & $\begin{array}{c}3 \mathrm{~g} / \mathrm{L} \text { (activity } \\
\text { not reported) }\end{array}$ & $\begin{array}{c}\text { Glycerol } 50 \% \\
(v / v) \\
\text { xanthan gum } \\
0.25 \%(w / v)\end{array}$ & $\begin{array}{l}\text { Ottawa } 20 / 30 \\
\text { and F-85 sands }\end{array}$ & $\begin{array}{l}\text { The addition of } \\
\text { xanthan gum } \\
\text { reduces UCS by } \\
25 \% \text {. While } \\
\text { glycerol does not } \\
\text { produce an } \\
\text { intact sample }\end{array}$ \\
\hline & Beser [94] & $20 \mathrm{~g} / \mathrm{L}$ & $49 \mathrm{~g} / \mathrm{L}$ & $\begin{array}{c}5 \mathrm{~g} / \mathrm{L} \text { (activity } \\
\text { not reported) }\end{array}$ & $\begin{array}{c}0.2 \% \text { FORTA } \\
\text { super-sweep } \\
\text { fine fiber } \\
\text { or } 3 \mathrm{~g} / \mathrm{L} \\
\text { nutrient broth }\end{array}$ & $\begin{array}{c}2095 \text { Granusil } \\
\text { silica sand }\end{array}$ & $\begin{array}{c}\text { addition of } \\
\text { nutrient broth to } \\
\text { the EICP samples } \\
\text { increased UCS } \\
\text { from } 2 \text { to } 6 \mathrm{MPa} \\
\text { while the addition } \\
\text { of fiber does not } \\
\text { have a } \\
\text { significant effect }\end{array}$ \\
\hline & $\begin{array}{l}\text { Hoang et al. } \\
\text { [24] }\end{array}$ & $0.3 \mathrm{M}$ & $0.3 \mathrm{M}$ & $\begin{array}{c}\text { Bacterial } \\
\text { enzyme } \\
\text { specified by } \\
\text { activity only } \\
(4-5 \mathrm{mM} \\
\text { urea/min) }\end{array}$ & - & $\begin{array}{c}\text { Ottawa } 20 / 30 \\
\text { silica sand }\end{array}$ & $\begin{array}{c}\text { Achieved an } \\
\text { unconfined } \\
\text { compressive } \\
\text { strength of } \\
1691 \mathrm{kPa} \text { using } \\
\text { bacterially derived } \\
\text { urease for EICP }\end{array}$ \\
\hline & Pandey [83] & $60 \mathrm{~g} / \mathrm{L}$ & $111 \mathrm{~g} / \mathrm{L}$ & $\begin{array}{c}5 \mathrm{~g} / \mathrm{L} \text { at activity } \\
\text { of } 678.70 \mu \mathrm{M} \\
\text { urea } / \mathrm{min}\end{array}$ & $\begin{array}{c}7.5 \%(w / w) \\
\text { PVA }\end{array}$ & $\begin{array}{l}\text { Ottawa graded } \\
\text { sand } \\
\text { Additionally, } \\
\text { Recycled glass } \\
\text { particles }\end{array}$ & $\begin{array}{c}\text { EICP for } 100 \% \\
\text { Ottawa graded } \\
\text { sand results in } \\
192 \text { psi. Adding } \\
20 \% \text { of recycled } \\
\text { glass reduces UCS } \\
\text { by } 70 \% \text {. } \\
\text { Adding PVA } \\
\text { reduce UCS } \\
\text { to } 151 \text { psi }\end{array}$ \\
\hline
\end{tabular}


Table A1. Cont.

\begin{tabular}{|c|c|c|c|c|c|c|c|}
\hline \multirow{2}{*}{ Application } & \multirow[b]{2}{*}{ Reference } & \multicolumn{4}{|c|}{ EICP Cementing Solution } & \multirow[b]{2}{*}{ Soil Type } & \multirow{2}{*}{$\begin{array}{l}\text { A Measure of Soil } \\
\text { Improvement and } \\
\text { General Remarks }\end{array}$} \\
\hline & & Urea & $\mathrm{CaCl}_{2}$ & $\begin{array}{c}\text { Jack Bean } \\
\text { Urease }\end{array}$ & Additives & & \\
\hline & $\begin{array}{l}\text { Almajed } \\
\text { et al. [56] }\end{array}$ & $\begin{array}{l}1.00 \text { to } \\
0.37 \mathrm{M}\end{array}$ & 0.67 to $0.25 \mathrm{M}$ & $\begin{array}{l}0.85 \mathrm{~g} / \mathrm{L} \\
\text { at activity of } \\
3500 \mathrm{U} / \mathrm{g}\end{array}$ & $\begin{array}{c}4 \mathrm{~g} / \mathrm{L} \text { of } \\
\text { powdered } \\
\text { milk }\end{array}$ & $\begin{array}{c}\text { Ottawa } 20 / 30 \\
\text { sand }\end{array}$ & $\begin{array}{l}\text { Adding powdered } \\
\text { milk to the solution } \\
\text { increases the } \\
\text { compressive } \\
\text { strength from } \\
0.12 \mathrm{MPa} \text { to up to } \\
1.82 \mathrm{MPa}\end{array}$ \\
\hline & $\begin{array}{l}\text { Almajed } \\
\text { [131] }\end{array}$ & $1 \mathrm{M}$ & $0.67 \mathrm{M}$ & $\begin{array}{l}3 \mathrm{~g} / \mathrm{L} \text { at activity } \\
\text { of } 3500 \mathrm{U} / \mathrm{g}\end{array}$ & $\begin{array}{l}4 \mathrm{~g} / \mathrm{L} \text { of milk } \\
\text { and } 300,500 \\
\text { or } 700 \text { of } \\
\text { Biochar mixed } \\
\text { with sand }\end{array}$ & $\begin{array}{l}\text { Local Crushed } \\
\text { clean silica } \\
\text { sand }\end{array}$ & $\begin{array}{l}\text { Adding biochar to } \\
\text { EICP require } \\
4 \text { cycles to achieve } \\
\text { UCS of obtained of } \\
\text { EICP alone }\end{array}$ \\
\hline & $\begin{array}{l}\text { Krishnan } \\
\text { et al. [112] }\end{array}$ & $1 \mathrm{M}$ & $0.67 \mathrm{M}$ & $\begin{array}{c}3 \mathrm{~g} / \mathrm{L} \text { urease at } \\
\text { activity of } \\
4200 \mathrm{U} / \mathrm{g}\end{array}$ & $\begin{array}{l}4 \mathrm{~g} / \mathrm{L} \text { nonfat } \\
\text { milk powder }\end{array}$ & Ottawa 20/30 & $\begin{array}{l}\text { Achieved UCS of } \\
\text { up to } 1.6 \mathrm{MPa} \text { at } \\
\text { carbonate } \\
\text { precipitation } \\
\text { of } 1.3 \%\end{array}$ \\
\hline & $\begin{array}{c}\text { Rohy et al. } \\
\text { [91] }\end{array}$ & 1,2 and $3 \mathrm{M}$ & $\begin{array}{c}0.67,1.34 \text { and } \\
2 \mathrm{M}\end{array}$ & $\begin{array}{c}3,9 \text { and } 6 \mathrm{~g} / \mathrm{L} \text { of } \\
\text { active Jack bean } \\
\text { meal at activity } \\
\text { of } 1500 \mathrm{U} / \mathrm{g}\end{array}$ & $\begin{array}{c}4,8 \text { and } \\
12 \mathrm{~g} / \mathrm{L} \text { of } \\
\text { nonfat dry } \\
\text { milk }\end{array}$ & $\begin{array}{l}\text { ASTM C778 } \\
\text { graded silica } \\
\text { sand }\end{array}$ & $\begin{array}{c}3 \mathrm{M} \text { solution } \\
\text { treatment at a } \\
\text { curing period of } \\
14 \text { days resulted in } \\
\text { UCS of up to } 3 \mathrm{MPa}\end{array}$ \\
\hline & $\begin{array}{l}\text { Refaei et al. } \\
\text { [82] }\end{array}$ & 1,2 and $3 \mathrm{M}$ & $\begin{array}{l}0.67,1.5 \\
\text { and } 2 \mathrm{M}\end{array}$ & $\begin{array}{c}3,6 \text {, and } 9 \mathrm{~g} / \mathrm{L} \\
\text { at activity of } \\
1500 \mathrm{U} / \mathrm{g}\end{array}$ & $\begin{array}{c}4,8 \text { and } \\
12 \mathrm{~g} / \mathrm{L} \text { of } \\
\text { non-fat dry } \\
\text { milk and } \\
\text { sodium } \\
\text { alginate at } \\
0.25,0.5 \text { and } \\
1 \%(w / w) \text { of } \\
\text { soil }\end{array}$ & $\begin{array}{l}\text { ASTM C778 } \\
\text { graded silica } \\
\text { sand }\end{array}$ & $\begin{array}{c}2 \mathrm{M} \text { solution at } \\
6 \mathrm{~g} / \mathrm{L} \text { urease and } \\
\text { sodium alginate of } \\
1 \% \text { resulted in a } \\
\text { maximum UCS of } \\
1800 \mathrm{kPa}\end{array}$ \\
\hline & $\begin{array}{l}\text { Hoang et al. } \\
\text { [49] }\end{array}$ & $\begin{array}{l}0.15 \mathrm{~mol} / \mathrm{L} \\
\text { and } 0.3 \mathrm{M}\end{array}$ & $\begin{array}{c}0.15 \mathrm{~mol} / \mathrm{L} \\
\text { and } 0.3 \mathrm{M}\end{array}$ & $\begin{array}{c}\text { The bacterial } \\
\text { enzyme at } \\
5 \mathrm{mM} \\
\text { (urea/min) }\end{array}$ & - & $\begin{array}{l}\text { coarse- and } \\
\text { fine-grained } \\
\text { sand }\end{array}$ & $\begin{array}{c}\text { BEICP-treated } \\
\text { sands ranged from } \\
400 \text { to } \\
1500 \mathrm{kPa}\end{array}$ \\
\hline & $\begin{array}{l}\text { Almajed } \\
\text { et al. [110] }\end{array}$ & $\begin{array}{l}0.5,1 \text { and } \\
2 \mathrm{M}\end{array}$ & $\begin{array}{c}0.335,0.5 \text { and } \\
1.34 \mathrm{M}\end{array}$ & $\begin{array}{l}1.5,3 \text { and } 6 \mathrm{~g} / \mathrm{L} \\
\text { bean meal } \\
\text { urease enzyme } \\
1500 \mathrm{U} / \mathrm{g}\end{array}$ & $\begin{array}{l}4 \mathrm{~g} / \mathrm{L} \text { nonfat } \\
\text { dry milk }\end{array}$ & $\begin{array}{l}\text { Ottawa } 20 / 30, \\
\text { filtration, } \\
\text { Alrasheed, and } \\
\text { Al-Nafud Sand }\end{array}$ & $\begin{array}{l}\text { EICP treatment for } \\
\text { the sand after one } \\
\text { cycle resulted in } \\
\text { higher compressive } \\
\text { strength than the } \\
\text { sands stabilized } \\
\text { using } 10 \% \text { OPC }\end{array}$ \\
\hline & $\begin{array}{l}\text { Cui et al. } \\
\text { [121] }\end{array}$ & $1.0 \mathrm{M}$ & $1.0 \mathrm{M}$ & $\begin{array}{c}40 \mathrm{U} / \mathrm{mL} \\
\text { (Extracted from } \\
\text { Bacteria) }\end{array}$ & - & $\begin{array}{c}\text { Ottawa } 20 / 30 \\
\text { sand }\end{array}$ & $\begin{array}{c}\text { EICP resulted in } \\
3 \mathrm{MPa} \text { compared to } \\
1 \mathrm{MPa} \text { at the same } \\
\text { carbonate content } \\
\text { of } 9 \%\end{array}$ \\
\hline & $\begin{array}{c}\text { Martin et al. } \\
\text { [37] }\end{array}$ & $1.5 \mathrm{M}$ & $1 \mathrm{M}$ & $\begin{array}{l}9,900 \mathrm{U} / \mathrm{L} \text { of } \\
\text { Urease }\end{array}$ & $\begin{array}{l}6 \mathrm{~g} / \mathrm{L} \text { nonfat } \\
\text { milk powder }\end{array}$ & $\begin{array}{l}\text { local quarry } \\
\text { sand }\end{array}$ & $\begin{array}{c}\text { Achieved an } \\
\text { average } \\
\text { compressive } \\
\text { strength of } 154 \mathrm{kPa}\end{array}$ \\
\hline & $\begin{array}{l}\text { Lee \& Kim } \\
\text { [95] }\end{array}$ & $\begin{array}{c}0.75,1.5 \text { and } \\
3 \mathrm{M}\end{array}$ & $\begin{array}{c}0.75,1.5 \text { and } \\
3 \mathrm{M}\end{array}$ & $\begin{array}{l}70 \text { \& } 140 \mathrm{~g} / \mathrm{L} \\
\text { (Soybean } \\
\text { Solution) at } \\
\text { Activity of } \\
0.4705 \\
\text { Ammonium } \\
\mathrm{mg} / \mathrm{L} / \mathrm{min}\end{array}$ & - & $\begin{array}{c}\text { Local Sand } \\
\text { from Hantan } \\
\text { River-South } \\
\text { Korea }\end{array}$ & $\begin{array}{c}\text { Achieved UCS up } \\
\text { to } 860 \mathrm{kPa}\end{array}$ \\
\hline & $\begin{array}{l}\text { Ahenkorah } \\
\text { et al. [92] }\end{array}$ & $0.5 \mathrm{M}$ & $0.5 \mathrm{M}$ & $\begin{array}{l}0.25 \mathrm{~g} / \mathrm{L} \text { at } \\
\text { activity of } \\
40,150 \mathrm{U} / \mathrm{g}\end{array}$ & $\begin{array}{l}4 \mathrm{~g} / \mathrm{L} \text { nonfat } \\
\text { dry milk }\end{array}$ & $\begin{array}{c}\text { Adelaide } \\
\text { Industrial (AI) } \\
\text { sand }\end{array}$ & $\begin{array}{l}\text { Achieved UCS of } \\
\text { up to } 4.23 \mathrm{MPa}\end{array}$ \\
\hline
\end{tabular}


Table A1. Cont.

\begin{tabular}{|c|c|c|c|c|c|c|c|}
\hline \multirow[b]{2}{*}{ Application } & \multirow[b]{2}{*}{ Reference } & \multicolumn{4}{|c|}{ EICP Cementing Solution } & \multirow[b]{2}{*}{ Soil Type } & \multirow{2}{*}{$\begin{array}{l}\text { A Measure of Soil } \\
\text { Improvement and } \\
\text { General Remarks }\end{array}$} \\
\hline & & Urea & $\mathrm{CaCl}_{2}$ & $\begin{array}{l}\text { Jack Bean } \\
\text { Urease }\end{array}$ & Additives & & \\
\hline & $\begin{array}{c}\text { Yuan et al. } \\
\text { [132] }\end{array}$ & $4.2 \mathrm{M}$ & $2.8 \mathrm{M}$ & $\begin{array}{l}100 \mathrm{~g} / \mathrm{L} \text { of } \\
\text { Urease }\end{array}$ & $\begin{array}{l}\text { Skim Milk } \\
\text { powder or } \\
\text { Rice Powder } \\
\quad \text { or } \\
\text { Brown sugar } \\
\text { (2 to } 32 \mathrm{~g} / \mathrm{L})\end{array}$ & $\begin{array}{l}\text { Local soil from } \\
\text { the Yellow } \\
\text { River flood } \\
\text { area in Kaifeng }\end{array}$ & $\begin{array}{c}\text { Achieved average } \\
\text { UCS of } 1489.3 \mathrm{kPa} \\
\text { for modified EICP } \\
\text { with up increase of } \\
\text { up to } 32.62 \% \text { over } \\
\text { nonmodified. }\end{array}$ \\
\hline & $\begin{array}{l}\text { Martin et al. } \\
\text { [118] }\end{array}$ & $1 \mathrm{M}$ & $0.67 \mathrm{M}$ & $12.6 \mathrm{kU} / \mathrm{L}$ & $\begin{array}{l}4 \mathrm{~g} / \mathrm{L} \text { nonfat } \\
\text { milk powder }\end{array}$ & $\begin{array}{l}\text { Ottawa 20/30, } \\
\text { F85, Glass } \\
\text { Beads and } \\
\text { Local washed } \\
\text { Quarry }\end{array}$ & $\begin{array}{c}\text { Reached UCS of } \\
1600 \mathrm{kPa} \text { at } 1.2 \\
\text { Carbonate Content } \\
\text { for Ottawa 20/30 }\end{array}$ \\
\hline & $\begin{array}{c}\text { Miftah et al. } \\
{[68]}\end{array}$ & $1 \mathrm{M}$ & $0.67 \mathrm{M}$ & $\begin{array}{c}1.25 \text { to } 15 \mathrm{~mL} / \mathrm{L} \\
\text { Crude Urease } \\
\text { Extract at } \\
\text { Activity of } \\
465 \mathrm{U} / \mathrm{mL}\end{array}$ & $\begin{array}{l}4 \mathrm{~g} / \mathrm{L} \text { nonfat } \\
\text { milk powder } \\
\text { Additionally, } \\
0 \%, 5 \% \text { and } \\
10 \% \text { of } \\
\text { Seawater }\end{array}$ & $\begin{array}{l}\text { Local beach } \\
\text { sand from } \\
\text { Famagusta } \\
\text { Bay-Cyprus }\end{array}$ & $\begin{array}{c}\text { Achieved UCS of } \\
0.255 \mathrm{MPa} \text { for } \\
\text { control samples } \\
\text { and } 0.224 \mathrm{MPa} \text { for } \\
\text { samples treated } \\
\text { with } 10 \% \text { Seawater }\end{array}$ \\
\hline & $\begin{array}{c}\text { Pratama et al. } \\
\text { [133] }\end{array}$ & $0.5 \mathrm{~mol} / \mathrm{L}$ & $0.5 \mathrm{~mol} / \mathrm{L}$ & $\begin{array}{l}20 \mathrm{~g} / \mathrm{L} \text { at } \\
\text { Activity of } \\
1668.7 \mathrm{U}\end{array}$ & - & Keisha sand & $\begin{array}{c}\text { Achieved UCS of } \\
600 \mathrm{kPa} \text { after } \\
3 \text { cycles }\end{array}$ \\
\hline \multirow{4}{*}{$\begin{array}{l}\text { Shear Wave } \\
\text { Velocity }\end{array}$} & $\begin{array}{l}\text { Song et al. } \\
\text { [2] }\end{array}$ & $1 \mathrm{M}$ & $1 \mathrm{M}$ & $\begin{array}{c}0.1,0.5 \text { and } \\
1 \mathrm{~g} / \mathrm{L} \text { at activity } \\
\text { of } 40,318 \mathrm{U} / \mathrm{g}\end{array}$ & - & $\begin{array}{c}\text { uniformly } \\
\text { graded natural } \\
\text { sand, }\end{array}$ & $\begin{array}{l}0.8 \mathrm{~ms} \text { to } 1.5 \mathrm{~ms} \\
\text { reduction in } \\
\text { electric } \\
\text { conductivity and } \\
800 \mathrm{~m} / \mathrm{s} \text { of shear } \\
\text { wave velocity for } \\
1 \mathrm{~g} / \mathrm{L} \text { of urease }\end{array}$ \\
\hline & $\begin{array}{c}\text { Obeidy et al. } \\
\text { [105] }\end{array}$ & NA & 0.1 and $0.2 \mathrm{M}$ & NA & $\begin{array}{l}\text { NA of dry } \\
\text { non-fat milk }\end{array}$ & $\begin{array}{c}\text { Ottawa } 20 / 30 \\
\text { sands }\end{array}$ & $\begin{array}{c}\text { Achieved } 600 \mathrm{~m} / \mathrm{s} \\
\text { of shear wave } \\
\text { velocity for sand } \\
\text { columns }\end{array}$ \\
\hline & $\begin{array}{l}\text { Song et al. } \\
\text { [101] }\end{array}$ & 1 to $1.5 \mathrm{M}$ & 0.5 and $1 \mathrm{M}$ & $\begin{array}{c}0.5 \text { to } 0.9 \mathrm{~g} / \mathrm{L} \text { of } \\
\text { Urease }\end{array}$ & - & $\begin{array}{c}\text { Ottawa } 50 / 70 \\
\text { or Jumunjin }\end{array}$ & $\begin{array}{l}\text { EICP treatment } \\
\text { increase the sand's } \\
\text { shear stiffness of } \\
\text { up to } 30 \text { times after } \\
6 \text { h of treatment. }\end{array}$ \\
\hline & $\begin{array}{c}\text { Nafisi et al. } \\
\text { [104] }\end{array}$ & $333 \mathrm{mM}$ & $100 \mathrm{mM}$ & $\begin{array}{c}0.55 \mathrm{~g} \text { at activity } \\
\text { of } 200 \mathrm{unit} / \mathrm{g}\end{array}$ & $\begin{array}{l}0.3 \mathrm{~g} \text { of nonfat } \\
\text { powder milk }\end{array}$ & $\begin{array}{c}\text { Ottawa } 20 / 30 \\
\text { or Ottawa } \\
50 / 70\end{array}$ & $\begin{array}{c}\text { Achieved shear } \\
\text { wave velocity of up } \\
\text { to } 700 \mathrm{~m} / \mathrm{s}\end{array}$ \\
\hline \multirow{5}{*}{$\begin{array}{l}\text { Permeability } \\
\text { Reduction }\end{array}$} & $\begin{array}{c}\text { Nemati \& } \\
\text { Voordouw } \\
\text { [9] }\end{array}$ & $12 \mathrm{~g} / \mathrm{L}$ & $30 \mathrm{~g} / \mathrm{L}$ & $\begin{array}{c}0.01,0.03 \text { and } \\
0.1 \mathrm{~g} / \mathrm{L} \\
\text { at } 26,100 \mathrm{U} / \mathrm{g}\end{array}$ & $4 \mathrm{~g} / \mathrm{L}$ & $\begin{array}{c}\text { Sand } 70 \% \& \\
\text { glass } 30 \% \\
(w / w \%)\end{array}$ & $\begin{array}{l}98 \% \text { reduction in } \\
\text { permeability after } \\
2 \text { injections }\end{array}$ \\
\hline & $\begin{array}{c}\text { Nemati et al. } \\
\text { [69] }\end{array}$ & $36 \mathrm{~g} / \mathrm{L}$ & $90 \mathrm{~g} / \mathrm{L}$ & $\begin{array}{c}0.3 \mathrm{~g} / \mathrm{L} \text { (activity } \\
\text { not reported) }\end{array}$ & - & $\begin{array}{c}\text { Sand } 70 \% \& \\
\text { glass } 30 \% \\
(w / w \%)\end{array}$ & $\begin{array}{l}62 \% \text { decrease in the } \\
\text { permeability when } \\
\text { using EICP }\end{array}$ \\
\hline & $\begin{array}{c}\text { Larsen et al. } \\
{[51]}\end{array}$ & $\begin{array}{l}88,110 \text { and } \\
132 \mathrm{~mol} / \mathrm{L}\end{array}$ & $\begin{array}{l}200,250 \text { and } \\
300 \mathrm{~mol} / \mathrm{L}\end{array}$ & $\begin{array}{l}\text { Urease active } \\
\text { bean meal of } \\
25 \mathrm{~g} / \mathrm{L} \text { at } \\
\text { activity of } \\
150 \mathrm{kU} / \mathrm{g}\end{array}$ & $\begin{array}{c}25 \mathrm{~g} / \mathrm{L} \\
\text { bentonite or } \\
\text { use of } \\
\text { large-grained } \\
\text { bean meal }\end{array}$ & - & $\begin{array}{l}\text { The addition of } \\
\text { bentonite highly } \\
\text { increase the } \\
\text { plugging efficiency } \\
\text { from } 1 \text { to } 2.9 \text { bar }\end{array}$ \\
\hline & $\begin{array}{l}\text { Yasuhara } \\
\text { et al. [26] }\end{array}$ & $\begin{array}{c}0.5 \text { and } 1.0 \\
\mathrm{~mol} / \mathrm{L}\end{array}$ & $\begin{array}{l}0.5 \text { and } 1.0 \\
\mathrm{~mol} / \mathrm{L}\end{array}$ & $\begin{array}{c}1 \text { and } 2 \mathrm{~g} / 300 \mathrm{~g} \\
\text { of sand } \\
\text { (activity not } \\
\text { reported) }\end{array}$ & - & Toyoura Sand & $\begin{array}{l}\text { Permeability of } \\
\text { treated sand is } \\
\text { reduced from } 10^{-1} \\
\text { to } 10^{-3} \mathrm{~cm} / \mathrm{s}\end{array}$ \\
\hline & $\begin{array}{l}\text { Neupane } \\
\text { et al. [60] }\end{array}$ & $0.5 \mathrm{~mol} / \mathrm{L}$ & $0.5 \mathrm{~mol} / \mathrm{L}$ & $\begin{array}{l}2 \mathrm{~g} / \mathrm{L} \text { at activity } \\
\text { of } 2950 \mathrm{U} / \mathrm{g}\end{array}$ & - & Sandy soil & $\begin{array}{c}\text { Reduction of } \\
\text { porosity from } 0.41 \\
\text { to } 0.382\end{array}$ \\
\hline
\end{tabular}


Table A1. Cont.

\begin{tabular}{|c|c|c|c|c|c|c|c|}
\hline \multirow[b]{2}{*}{ Application } & \multirow[b]{2}{*}{ Reference } & \multicolumn{4}{|c|}{ EICP Cementing Solution } & \multirow[b]{2}{*}{ Soil Type } & \multirow{2}{*}{$\begin{array}{l}\text { A Measure of Soil } \\
\text { Improvement and } \\
\text { General Remarks }\end{array}$} \\
\hline & & Urea & $\mathrm{CaCl}_{2}$ & $\begin{array}{l}\text { Jack Bean } \\
\text { Urease }\end{array}$ & Additives & & \\
\hline & $\begin{array}{l}\text { Handley- } \\
\text { Sidhu et al. } \\
\text { [52] }\end{array}$ & $\begin{array}{l}400 \text { and } \\
200 \mathrm{mM}\end{array}$ & $\begin{array}{l}400 \mathrm{mM} \text { and } \\
200 \mathrm{mM}\end{array}$ & $\begin{array}{l}0.25 \& 0.5 \mathrm{~g} / \mathrm{L} \\
\text { (activity not } \\
\text { reported) }\end{array}$ & - & $\begin{array}{l}\text { borosilicate } \\
\text { beads }\end{array}$ & $\begin{array}{l}\text { Permeability was } \\
\text { reduced from } 9.99 \\
\text { to } 0.175 \text { Darcy }\end{array}$ \\
\hline & $\begin{array}{c}\text { Putra et al. } \\
\text { [98] }\end{array}$ & $0.5 \mathrm{~g} / \mathrm{L}$ & $0.5 \mathrm{~g} / \mathrm{L}$ & $1 \mathrm{~g} / \mathrm{L}$ & - & Keisa sand & $\begin{array}{l}\text { Hydraulic } \\
\text { Conductivity } \\
\text { reduced to less } \\
\text { than } 0.02 \mathrm{~cm} / \mathrm{s}\end{array}$ \\
\hline & $\begin{array}{c}\text { Hoang et al. } \\
\text { [24] }\end{array}$ & $0.3 \mathrm{M}$ & $0.3 \mathrm{M}$ & $\begin{array}{c}\text { Bacterial } \\
\text { enzyme } \\
\text { specified by } \\
\text { activity only } \\
(4-5 \mathrm{mM} \\
\text { urea/min) }\end{array}$ & - & $\begin{array}{c}\text { Ottawa } 20 / 30 \\
\text { silica sand }\end{array}$ & $\begin{array}{c}\text { one-log decrease in } \\
\text { permeability after } \\
\text { sixteenth cycle } \\
\text { treatment }\end{array}$ \\
\hline & $\begin{array}{c}\text { Hoang et al. } \\
{[49]}\end{array}$ & $\begin{array}{c}0.15 \mathrm{~mol} / \mathrm{L} \\
\text { and } 0.3 \mathrm{M}\end{array}$ & $\begin{array}{c}0.15 \mathrm{~mol} / \mathrm{L} \\
\text { and } 0.3 \mathrm{M}\end{array}$ & $\begin{array}{c}\text { Bacterial } \\
\text { enzyme at } \\
5 \mathrm{mM} \\
\text { (urea/min) }\end{array}$ & - & $\begin{array}{l}\text { coarse- and } \\
\text { fine-grained } \\
\text { sand }\end{array}$ & $\begin{array}{l}\text { Permeability } \\
\text { reduction from } \\
10^{-1} \text { to } 10^{-2} \text { was } \\
\text { achieved after } \\
\text { BEICP treatment }\end{array}$ \\
\hline \multirow{2}{*}{$\begin{array}{l}\text { Water and } \\
\text { Vapor } \\
\text { Retention to } \\
\text { Enhance } \\
\text { Groutability }\end{array}$} & $\begin{array}{l}\text { Hamdan } \\
\text { et al. [125] }\end{array}$ & 0.6 and $3.0 \mathrm{M}$ & 0.4 and $2.0 \mathrm{M}$ & $\begin{array}{c}0.44 \mathrm{~g} / \mathrm{L} \text { for } \\
\text { high activity } \\
(26,100 \text { units } / \mathrm{g}) \\
\text { and } 0.85 \mathrm{~g} / \mathrm{L} \text { for } \\
\text { low activity } \\
\text { enzyme } \\
(200 \mathrm{~g} / \mathrm{U})\end{array}$ & $\begin{array}{c}4.0 \mathrm{~g} / \mathrm{L} \text { of } \\
\text { unspecified } \\
\text { stabilizer } \\
(0.1 \text { to } 5 \%) \text { of } \\
\text { guar gum and } \\
\text { xanthan gum) } \\
\text { and } 5 \% \text { to } \\
30 \% \text { of polyol- } \\
\text { cellulose } \\
\text { hydrogel }\end{array}$ & $\begin{array}{l}\text { F-60 } \\
\text { fine-grained } \\
\text { silica sand }\end{array}$ & $\begin{array}{l}17 \% \text { reduction in } \\
\text { vapor pressure at } \\
2 \% \text { guar gum and } \\
47 \% \text { reduction } \\
\text { while using } \\
\text { guar gum. }\end{array}$ \\
\hline & $\begin{array}{l}\text { Pasillas et al. } \\
\text { [37] }\end{array}$ & $1 \mathrm{M}$ & $0.67 \mathrm{M}$ & $\begin{array}{c}3 \mathrm{~g} / \mathrm{L} \text { (activity } \\
\text { not reported) }\end{array}$ & $\begin{array}{l}\text { Glycerol 50\% } \\
(v / v) \text { xanthan } \\
\text { gum } 0.25 \% \\
(w / v)\end{array}$ & $\begin{array}{l}\text { Ottawa } 20 / 30 \\
\text { and F-85 sands }\end{array}$ & $\begin{array}{l}\text { The addition of } \\
\text { xanthan gum } \\
\text { enhanced water } \\
\text { retention the most } \\
\text { at retaining } 74 \% \\
\text { of the } \\
\text { original solution }\end{array}$ \\
\hline \multirow{2}{*}{$\begin{array}{c}\text { Direct Shear } \\
\text { Test }\end{array}$} & $\begin{array}{l}\text { Aishwarya \& } \\
\text { Christy [102] }\end{array}$ & 1 and $2 \mathrm{M}$ & $0.5,1$, and $2 \mathrm{M}$ & $\begin{array}{c}1 \mathrm{mg} \text { of this } \\
\text { urease active } \\
\text { the meal can } \\
\text { hydrolyze } 3 \mathrm{mg} \\
\text { of urea in } \\
30 \mathrm{~min} \text { at } 37^{\circ} \mathrm{C}\end{array}$ & - & $\begin{array}{l}\text { Gujarat and } \\
\text { Yamuna sand }\end{array}$ & $\begin{array}{l}\text { Shear strength } \\
\text { increase in the } \\
\text { range of } 40-50 \%\end{array}$ \\
\hline & $\begin{array}{c}\text { Putra et al. } \\
\text { [103] }\end{array}$ & $1 \mathrm{~mol} / \mathrm{L}$ & $\begin{array}{l}0.9 \text { to } 1 \mathrm{~mol} / \mathrm{L} \\
\text { Calcium } \\
\text { Chloride and } 0 \\
\text { to } 0.1 \\
\text { Magnesium } \\
\text { Chloride }\end{array}$ & $2 \mathrm{~g} / \mathrm{L}$ & - & Silica sand & $\begin{array}{c}\text { Achieved a } \\
\text { cohesion of } 53 \mathrm{kPa} \\
\text { at } 4.1 \% \text { carbonate } \\
\text { content }\end{array}$ \\
\hline \multirow[b]{2}{*}{$\begin{array}{l}\text { Fugitive Dust } \\
\text { Control }\end{array}$} & $\begin{array}{c}\text { Bang et al. } \\
{[28]}\end{array}$ & $0.333 \mathrm{~mol} / \mathrm{L}$ & $0.1 \mathrm{~mol} / \mathrm{L}$ & 0.5 units $/ \mathrm{mL}$ & $\begin{array}{l}0 \% \text { to } 1 \% 1 \mathrm{~L} \\
\text { solution. }\end{array}$ & $\begin{array}{l}\text { Poorly graded } \\
\text { sand }\end{array}$ & $\begin{array}{l}\text { EICP resulted in } \\
0.01 \% \text { weight loss } \\
\text { at } 9 \mathrm{~m} / \mathrm{s} \text { wind } \\
\text { speed }\end{array}$ \\
\hline & Knorr [29] & $\begin{array}{c}1 \text { and } \\
2 \mathrm{~mol} / \mathrm{L}\end{array}$ & $\begin{array}{l}0.375 \text { to } \\
2 \mathrm{~mol} / \mathrm{L}\end{array}$ & $\begin{array}{c}0.5 \mathrm{~g} / \mathrm{L} \text { (activity } \\
\text { not reported) }\end{array}$ & $4 \mathrm{~g} / \mathrm{L}$ & $\begin{array}{c}\text { Arizona } \\
\text { silty-sand, } \\
\text { medium- } \\
\text { grained silica } \\
\text { sand, and mine } \\
\text { tailings }\end{array}$ & $\begin{array}{c}\text { Achieved average } \\
\text { detachment } \\
\text { velocity of }>25 \mathrm{~m} / \mathrm{s}\end{array}$ \\
\hline
\end{tabular}


Table A1. Cont.

\begin{tabular}{|c|c|c|c|c|c|c|c|}
\hline \multirow[b]{2}{*}{ Application } & \multirow[b]{2}{*}{ Reference } & \multicolumn{4}{|c|}{ EICP Cementing Solution } & \multirow[b]{2}{*}{ Soil Type } & \multirow{2}{*}{$\begin{array}{l}\text { A Measure of Soil } \\
\text { Improvement and } \\
\text { General Remarks }\end{array}$} \\
\hline & & Urea & $\mathrm{CaCl}_{2}$ & $\begin{array}{l}\text { Jack Bean } \\
\text { Urease }\end{array}$ & Additives & & \\
\hline & $\begin{array}{c}\text { Hamadan \& } \\
\text { Kavazanjian } \\
\text { [27] }\end{array}$ & 0.075 to $3 \mathrm{M}$ & 0.05 to $2 \mathrm{M}$ & $\begin{array}{l}0 \mathrm{~g} / \mathrm{L} \text { and } \\
0.45 \mathrm{~g} / \mathrm{L} \text { at } \\
\text { activity of } \\
26,100 \mathrm{U} / \mathrm{g}\end{array}$ & $\begin{array}{c}4 \mathrm{~g} / \mathrm{L} \text { of } \\
\text { powdered } \\
\text { nonfat milk }\end{array}$ & $\begin{array}{c}\text { uniform, } \\
\text { fine-grained, } \\
\text { clean Ottawa } \\
\text { F-60 silica sand, } \\
\text { well-graded } \\
\text { native Arizona } \\
\text { silty fine sand; } \\
\text { and mine } \\
\text { tailings } \\
\text { obtained } \\
\text { from a site in } \\
\text { southern } \\
\text { Arizona }\end{array}$ & $\begin{array}{c}\text { Achieved a } \\
\text { detachment } \\
\text { velocity of }>25 \mathrm{~m} / \mathrm{s} \\
\text { for the } 3 \text { treated } \\
\text { soil types }\end{array}$ \\
\hline & $\begin{array}{l}\text { Almajed } \\
\text { et al. [32] }\end{array}$ & $1 \mathrm{~mol} / \mathrm{L}$ & $\begin{array}{l}0.67 \text { and } \\
1 \mathrm{~mol} / \mathrm{L}\end{array}$ & $\begin{array}{l}3 \mathrm{~g} / \mathrm{L} \text { at activity } \\
\text { of } 1500 \mathrm{U} / \mathrm{g}\end{array}$ & $\begin{array}{c}4 \mathrm{~g} / \mathrm{L} \text { of } \\
\text { powdered } \\
\text { milk and } \\
0.5 \%, 1 \% \text { or } \\
2 \% \text { of sodium } \\
\text { alginate } \\
(w / w \%) \text { of } \\
\text { solution }\end{array}$ & $\begin{array}{l}\text { Nafud desert } \\
\text { sand }\end{array}$ & $\begin{array}{l}\text { Combinations of } \\
\text { EICP and Sodium } \\
\text { alginate had a } 0 \% \\
\text { erosion rate } \\
\text { compared to other } \\
\text { combinations }\end{array}$ \\
\hline & $\begin{array}{l}\text { Miao et al. } \\
\text { [84] }\end{array}$ & $0.75 \mathrm{~mol} / \mathrm{L}$ & $\begin{array}{l}0.75 \mathrm{~mol} / \mathrm{L} \\
\text { calcium } \\
\text { acetate }\end{array}$ & $\begin{array}{l}\text { Urease from } \\
\text { soybeans at } \\
4000 \mathrm{U} / \mathrm{L}\end{array}$ & - & $\begin{array}{l}\text { Tengger desert } \\
\text { sand }\end{array}$ & $\begin{array}{c}\text { EICP Treated } \\
29.1 \mathrm{~m} / \mathrm{s} \text {. Higher } \\
\text { spray passes lead } \\
\text { to more wind } \\
\text { erosion resistance }\end{array}$ \\
\hline & $\begin{array}{l}\text { Martin et al. } \\
\text { [37] }\end{array}$ & $1.5 \mathrm{M}$ & $1 \mathrm{M}$ & $\begin{array}{l}9900 \mathrm{U} / \mathrm{L} \text { of } \\
\text { Urease }\end{array}$ & $\begin{array}{l}6 \mathrm{~g} / \mathrm{L} \text { nonfat } \\
\text { milk powder }\end{array}$ & $\begin{array}{l}\text { local quarry } \\
\text { sand }\end{array}$ & $\begin{array}{c}\text { Needle penetrating } \\
\text { test resulted in } \\
348 \mathrm{~N} \text { surface } \\
\text { strength of treated } \\
\text { sample compared } \\
\text { to } 35 \mathrm{~N} \text { for the } \\
\text { control sample }\end{array}$ \\
\hline \multirow{3}{*}{$\begin{array}{c}\text { Cyclic Triaxial } \\
\text { Test }\end{array}$} & Hamdan [58] & $\begin{array}{c}400 \mathrm{mM} \text { and } \\
1 \mathrm{M}\end{array}$ & $\begin{array}{c}300 \mathrm{mM} \text { and } \\
1 \mathrm{M}\end{array}$ & $2.0 \mathrm{~g} / \mathrm{L}$ & - & $\begin{array}{l}\text { Ottawa 20/30 } \\
\text { sand and } \\
\text { Ottawa F-60 } \\
\text { silica sand }\end{array}$ & $\begin{array}{l}\text { 20-30 silica sand } \\
\text { resulted in a } \\
\text { strength increase of } \\
100 \mathrm{kPa} \text { at } 2 \% \\
\text { carbonate content } \\
\text { whereas } \\
\text { F-60-treated silica } \\
\text { sand increased up } \\
\text { to } 125 \mathrm{kPa} \text { at } 1.6 \%\end{array}$ \\
\hline & $\begin{array}{l}\text { Simatupang } \\
\text { and } \\
\text { Okamura } \\
\text { [33] }\end{array}$ & $\begin{array}{c}0 \text { to } \\
0.3 \mathrm{~mol} / \mathrm{L}\end{array}$ & 0 to $0.3 \mathrm{~mol} / \mathrm{L}$ & $\begin{array}{l}0 \text { to } 35 \mathrm{~g} / \mathrm{L} \\
\text { (activity not } \\
\text { reported) }\end{array}$ & - & $\begin{array}{c}\text { Tohoku Keisha } \\
\text { No. } 4\end{array}$ & $\begin{array}{l}\text { Only } 1 \% \text { of } \\
\text { carbonate content } \\
\text { is required to } \\
\text { double the } \\
\text { liquefaction } \\
\text { resistance for } \\
\text { up to } 0.4\end{array}$ \\
\hline & Almajed [44] & $1 \mathrm{M}$ & $0.67 \mathrm{M}$ & $\begin{array}{c}3 \mathrm{~g} / \mathrm{L} \text { at activity } \\
\text { of } 3500 \mathrm{U} / \mathrm{g}\end{array}$ & $\begin{array}{c}4 \mathrm{~g} / \mathrm{L} \text { non-fat } \\
\text { dry milk }\end{array}$ & $\begin{array}{c}\text { Ottawa } 20 / 30 \\
\text { sand }\end{array}$ & $\begin{array}{c}\text { Internal friction } \\
\text { angle and effective } \\
\text { stress cohesion } \\
\text { were calculated as } \\
34.58^{\circ} \text { and } \\
332.96 \mathrm{kPa}\end{array}$ \\
\hline
\end{tabular}


Table A1. Cont.

\begin{tabular}{|c|c|c|c|c|c|c|c|}
\hline \multirow[b]{2}{*}{ Application } & \multirow[b]{2}{*}{ Reference } & \multicolumn{4}{|c|}{ EICP Cementing Solution } & \multirow[b]{2}{*}{ Soil Type } & \multirow{2}{*}{$\begin{array}{l}\text { A Measure of Soil } \\
\text { Improvement and } \\
\text { General Remarks }\end{array}$} \\
\hline & & Urea & $\mathrm{CaCl}_{2}$ & $\begin{array}{l}\text { Jack Bean } \\
\text { Urease }\end{array}$ & Additives & & \\
\hline & He et al. [50] & $0.5 \mathrm{~mol} / \mathrm{L}$ & $0.5 \mathrm{~mol} / \mathrm{L}$ & $\begin{array}{c}\text { Bacterial } \\
\text { enzyme at } \\
0.33 \mathrm{~mL} / \mathrm{mL} \\
(w / w) \text { of } \\
\text { solution } \\
\text { (activity not } \\
\text { reported) }\end{array}$ & - & $\begin{array}{l}\text { Ottawa sand } \\
\text { (ASTM graded) } \\
\text { with quartz } \\
\text { powder }\end{array}$ & $\begin{array}{l}10 \text { passes of } \\
\text { treatment solution } \\
\text { resulted in the } \\
\text { highest deviator } \\
\text { stress results of } \\
1750 \mathrm{kPa}\end{array}$ \\
\hline & $\begin{array}{c}\text { Gao et al. } \\
\text { [48] }\end{array}$ & $\begin{array}{c}0.25 \text { and } 0.5 \\
\mathrm{~mol} / \mathrm{L}\end{array}$ & $\begin{array}{c}0.25 \text { and } 0.5 \\
\mathrm{~mol} / \mathrm{L}\end{array}$ & $\begin{array}{l}40 \text { and } 130 \mathrm{~g} / \mathrm{L} \\
\text { Soybean } \\
\text { concentration at } \\
\text { an activity of } \\
6.5 \text { and } \\
13.2 \mathrm{mM} / \mathrm{min}\end{array}$ & - & $\begin{array}{l}\text { Quartz sand } \\
\text { and Ottawa } \\
\text { sand }\end{array}$ & $\begin{array}{c}\text { Achieved } \\
\text { maximum axial } \\
\text { stress of } 250 \mathrm{kPa} \\
\text { after } 15 \text { treatments. }\end{array}$ \\
\hline $\begin{array}{l}\text { Crack Healing } \\
\text { in Concrete }\end{array}$ & $\begin{array}{l}\text { Dakhane } \\
\text { et al. [36] }\end{array}$ & 0.6 and $1.2 \mathrm{M}$ & 0.5 and $1 \mathrm{M}$ & $\begin{array}{c}1 \mathrm{~g} / \mathrm{L} \text { at activity } \\
\text { of } 200 \mathrm{U} / \mathrm{g}\end{array}$ & $\begin{array}{l}2 \mathrm{~g} / \mathrm{L} \text { of } \\
\text { non-fat dry } \\
\text { milk }\end{array}$ & - & $\begin{array}{c}33 \% \text { enhancement } \\
\text { of flexural strength } \\
\text { for mortars treated } \\
\text { with EICP }\end{array}$ \\
\hline $\begin{array}{l}\text { Tensile } \\
\text { Strength }\end{array}$ & $\begin{array}{l}\text { Ahenkorah } \\
\text { et al. [92] }\end{array}$ & $0.5 \mathrm{M}$ & $0.5 \mathrm{M}$ & $\begin{array}{c}0.25 \mathrm{~g} / \mathrm{L} \text { at } \\
\text { activity of } \\
40,150 \mathrm{U} / \mathrm{g}\end{array}$ & $\begin{array}{l}4 \mathrm{~g} / \mathrm{L} \text { nonfat } \\
\text { dry milk }\end{array}$ & $\begin{array}{c}\text { Adelaide } \\
\text { Industrial (AI) } \\
\text { sand }\end{array}$ & $\begin{array}{c}\text { Achieved a } \\
\text { splitting tensile } \\
\text { strength of } 1 \mathrm{MPa} \\
\text { at } 11.6 \% \text { carbonate } \\
\text { content. }\end{array}$ \\
\hline \multirow{2}{*}{ Water Erosion } & $\begin{array}{l}\text { Cuccurullo } \\
\text { et al. [128] }\end{array}$ & $2 \mathrm{~mol} / \mathrm{L}$ & $2 \mathrm{~mol} / \mathrm{L}$ & $\begin{array}{l}\text { Crude Soybean } \\
\text { Extracts }\end{array}$ & - & $\begin{array}{l}\text { Silty Clay from } \\
\text { (Bouisset } \\
\text { brickwork } \\
\text { factory - } \\
\text { France) }\end{array}$ & $\begin{array}{c}\text { Treated soil } \\
\text { reported } \\
\text { significantly lower } \\
\text { weight loss due to } \\
\text { water erosion and } \\
\text { did not experience } \\
\text { any cracks } \\
\text { or swelling. }\end{array}$ \\
\hline & $\begin{array}{l}\text { Ossai et al. } \\
\text { [35] }\end{array}$ & 1 and $2 \mathrm{M}$ & 0.67 and $1.34 \mathrm{M}$ & $3 \mathrm{~g} / \mathrm{L}$ & $\begin{array}{l}4 \mathrm{~g} / \mathrm{L} \text { nonfat } \\
\text { dry milk }\end{array}$ & $\begin{array}{l}\text { Two natural } \\
\text { quartz sand } \\
\text { and Ottawa } \\
20 / 30\end{array}$ & $\begin{array}{l}\text { The average } \\
\text { percent loss of fines } \\
\text { due to pre-rinsing } \\
\text { was } 1.6 \% \text { for } \\
\text { natural sands and } \\
\text { almost } 0 \% \text { for } \\
\text { Ottawa } 20 / 30\end{array}$ \\
\hline Biobricks & $\begin{array}{l}\text { Arab et al. } \\
\text { [34] }\end{array}$ & 1,2 , and $3 \mathrm{M}$ & $\begin{array}{c}0.67,1.34, \text { and } \\
2 \mathrm{M}\end{array}$ & $3 \mathrm{~g} / \mathrm{L}$ & $\begin{array}{l}4 \mathrm{~g} / \mathrm{L} \text { nonfat } \\
\text { dry milk and } \\
0 . \text { To } 1.5 \% \text { of } \\
\text { soil dry mass } \\
\text { Sodium } \\
\text { Alginate }\end{array}$ & $\begin{array}{c}\text { Graded silica } \\
\text { sand ASTM } \\
\text { C778 }\end{array}$ & $\begin{array}{l}\text { Achieved UCS of } \\
1800 \mathrm{kPa} \text {, and } \\
\text { flexural strength of } \\
2200 \mathrm{kPa} \text { and } \\
\text { thermal } \\
\text { conductivity of } \\
0.25 \mathrm{~W} / \mathrm{mK} \text {, and } \\
\text { initial rate of } \\
\text { absorption of } \\
16.29 \mathrm{~g} / \mathrm{min} / 50 \mathrm{~cm}^{2}\end{array}$ \\
\hline
\end{tabular}

\section{References}

1. DeJong, J.T.; Mortensen, B.M.; Martinez, B.C.; Nelson, D.C. Bio-mediated soil improvement. Ecol. Eng. 2010, 36, 197-210. [CrossRef]

2. Song, J.Y.; Kim, Y.; Jang, J.; Yun, T.S.; Sim, Y. Microstructure of Bio-mediated Sand by Enzyme Induced Carbonate Precipitation: Relevance to Physio-Mechanical Properties. In Proceedings of the 7th International Conference on Unsaturated Soils, Hong Kong, China, 3-5 August 2018.

3. Kavazanjian, E.; Hamdan, N. Enzyme Induced Carbonate Precipitation (EICP) Columns for Ground Improvement. In IFCEE 2015; American Society of Civil Engineers (ASCE): Reston, VA, USA, 2015.

4. Cheng, L.; Shahin, M.A. Microbially Induced Calcite Precipitation (MICP) for Soil Stabilization. In Ecological Wisdom Inspired Restoration Engineering; Springer: Singapore, 2019; pp. 47-68. 
5. Mujah, D.; Cheng, L.; Shahin, M. Microstructural and Geomechanical Study on Biocemented Sand for Optimization of MICP Process. J. Mater. Civ. Eng. 2019, 31, 04019025. [CrossRef]

6. Holten-Andersen, N.; Jaishankar, A.; Harrington, M.J.; Fullenkamp, D.E.; DiMarco, G.; He, L.; McKinley, G.H.; Messersmith, P.B.; Lee, K.Y.C. Metal-coordination: Using one of nature's tricks to control soft material mechanics. J. Mater. Chem. B 2014, 2, 2467-2472. [CrossRef]

7. Castanier, S.; Le Métayer-Levrel, G.; Perthuisot, J.-P. Ca-carbonates precipitation and limestone genesis-The microbiogeologist point of view. Sediment. Geol. 1999, 126, 9-23. [CrossRef]

8. Kavazanjian, E.; Karatas, I. Microbiological Improvement of the Physical Properties of Soil. In Proceedings of the 6th International Conference on Case Histories in Geotechnical Engineering, Arlington, VA, USA, 11-16 August 2008.

9. Nemati, M.; Voordouw, G. Modification of porous media permeability, using calcium carbonate produced enzymatically in situ. Enzyme Microb. Technol. 2003, 33, 635-642. [CrossRef]

10. Whiffin, V.S. Microbial $\mathrm{CaCO}_{3}$ Precipitation for the Production of Biocement. Ph.D. Thesis, Murdoch University, Perth, WA, Australia, 2004.

11. DeJong, J.T.; Fritzges, M.B.; Nüsslein, K. Microbially Induced Cementation to Control Sand Response to Undrained Shear. J. Geotech. Geoenviron. Eng. 2006, 132, 1381-1392. [CrossRef]

12. Whiffin, V.S.; van Paassen, L.; Harkes, M.P. Microbial Carbonate Precipitation as a Soil Improvement Technique. Geomicrobiol. J. 2007, 24, 417-423. [CrossRef]

13. Harkes, M.P.; van Paassen, L.A.; Booster, J.L.; Whiffin, V.S.; van Loosdrecht, M.C.M. Fixation and distribution of bacterial activity in sand to induce carbonate precipitation for ground reinforcement. Ecol. Eng. 2010, 36, 112-117. [CrossRef]

14. Dejong, J.T.; Soga, K.; Kavazanjian, E.; Burns, S.; VAN Paassen, L.A.; AL Qabany, A.; Aydilek, A.; Bang, S.S.; Burbank, M.; Caslake, L.F.; et al. Biogeochemical processes and geotechnical applications: Progress, opportunities and challenges. In Bio- and Chemo-Mechanical Processes in Geotechnical Engineering; Thomas Telford Ltd.: London, UK, 2014; pp. 143-157.

15. Van Paassen, L.A.; Ghose, R.; Van Der Linden, T.J.M.; Van Der Star, W.R.L.; Van Loosdrecht, M.C.M. Quantifying Biomediated Ground Improvement by Ureolysis: Large-Scale Biogrout Experiment. J. Geotech. Geoenviron. Eng. 2010, 136, 1721-1728. [CrossRef]

16. Cheng, L.; Cord-Ruwisch, R.; Shahin, M. Cementation of sand soil by microbially induced calcite precipitation at various degrees of saturation. Can. Geotech. J. 2013, 50, 81-90. [CrossRef]

17. Mujah, D.; Shahin, M.A.; Cheng, L. State-of-the-Art Review of Biocementation by Microbially Induced Calcite Precipitation (MICP) for Soil Stabilization. Geomicrobiol. J. 2016, 34, 524-537. [CrossRef]

18. Shahin, M.A.; Jamieson, K.; Cheng, L. Microbial-induced carbonate precipitation for coastal erosion mitigation of sandy slopes. Géotechnique Lett. 2020, 10, 211-215. [CrossRef]

19. Khodadadi, T.H.; Kavazanjian, E.; Van Paassen, L.; DeJong, J. Bio-Grout Materials: A Review. In Proceedings of the Grouting 2017; American Society of Civil Engineers: Reston, VA, USA, 2017; pp. 1-12. [CrossRef]

20. Cheng, L.; Shahin, M.A.; Chu, J. Soil bio-cementation using a new one-phase low-pH injection method. Acta Geotech. 2019, 14, 615-626. [CrossRef]

21. Al-Thawadi, S.M. High Strength in situ Biocementation of Soil by Calcite Precipitating Locally Isolated Ureolytic Bacteria. Ph.D. Thesis, Murdoch University, Perth, WA, Australia, 2008.

22. Ivanov, V.; Chu, J. Applications of microorganisms to geotechnical engineering for bioclogging and biocementation of soil in situ. Rev. Environ. Sci. Bio/Technol. 2008, 7, 139-153. [CrossRef]

23. Li, M.; Wen, K.; Li, Y.; Zhu, L. Impact of Oxygen Availability on Microbially Induced Calcite Precipitation (MICP) Treatment. Geomicrobiol. J. 2017, 35, 15-22. [CrossRef]

24. Hoang, T.; Alleman, J.; Cetin, B.; Ikuma, K.; Choi, S.-G. Sand and silty-sand soil stabilization using bacterial enzyme-induced calcite precipitation (BEICP). Can. Geotech. J. 2019, 56, 808-822. [CrossRef]

25. Yasuhara, H.; Hayashi, K.; Okamura, M. Evolution in Mechanical and Hydraulic Properties of Calcite-Cemented Sand Mediated by Biocatalyst. In Geo-Frontiers 2011; American Society of Civil Engineers (ASCE): Reston, VA, USA, 2011 ; pp. $3984-3992$.

26. Yasuhara, H.; Neupane, D.; Hayashi, K.; Okamura, M. Experiments and predictions of physical properties of sand cemented by enzymatically-induced carbonate precipitation. Soils Found. 2012, 52, 539-549. [CrossRef]

27. Hamdan, N.; Kavazanjian, E. Enzyme-induced carbonate mineral precipitation for fugitive dust control. Géotechnique 2016, 66, 546-555. [CrossRef]

28. Bang, S.S.; Bang, S.; Frutiger, S.; Nehl, L.M.; Comes, B.L. Application of novel biological technique in dust suppression (No. 09-0831). In Proceedings of the Transportation Research Board 88th Annual Meeting, Washington, DC, USA, 11-15 January 2009.

29. Knorr, B. Enzyme-Induced Carbonate Precipitation for the Mitigation of Fugitive Dust. Master's Thesis, Arizona State University, Tempe, AZ, USA, 2014.

30. Wu, M.; Hu, X.; Zhang, Q.; Zhao, Y.; Sun, J.; Cheng, W.; Fan, Y.; Zhu, S.; Lu, W.; Song, C. Preparation and performance evaluation of environment-friendly biological dust suppressant. J. Clean. Prod. 2020, 273, 123162. [CrossRef]

31. Raymond, A.J.; Purdy, C.; Fox, T.; Kendall, A.; DeJong, J.T.; Kavazanjian, E., Jr.; Martin, K.; Woolley, M. Life cycle sustainability assessment of enzyme-induced carbonate precipitation (EICP) for fugitive dust control. Acad. J. Civ. Eng. 2019, 37, 600-607. [CrossRef] 
32. Almajed, A.; Lemboye, K.; Arab, M.G.; Alnuaim, A. Mitigating wind erosion of sand using biopolymer-assisted EICP technique. Soils Found. 2020, 60, 356-371. [CrossRef]

33. Simatupang, M.; Okamura, M. Liquefaction resistance of sand remediated with carbonate precipitation at different degrees of saturation during curing. Soils Found. 2017, 57, 619-631. [CrossRef]

34. Arab, M.G.; Omar, M.; Almajed, A.; Elbaz, Y.; Ahmed, A.H. Hybrid technique to produce bio-bricks using enzyme-induced carbonate precipitation (EICP) and sodium alginate biopolymer. Constr. Build. Mater. 2021, 284, 122846. [CrossRef]

35. Ossai, R.; Rivera, L.; Bandini, P. Experimental Study to Determine an EICP Application Method Feasible for Field Treatment for Soil Erosion Control. In Geo-Congress 2020; American Society of Civil Engineers (ASCE): Reston, VA, USA, 2020 ; pp. $205-213$.

36. Dakhane, A.; Das, S.; Hansen, H.; O’Donnell, S.; Hanoon, F.; Rushton, A.; Perla, C.; Neithalath, N. Crack Healing in Cementitious Mortars Using Enzyme-Induced Carbonate Precipitation: Quantification Based on Fracture Response. J. Mater. Civ. Eng. 2018, 30, 04018035. [CrossRef]

37. Martin, K.K.; Khodadadi, T.H.; Kavazanjian, E., Jr. Enzyme-induced carbonate precipitation: Scale-up of bio-cemented soil columns. In Geo-Congress 2020: Biogeotechnics; American Society of Civil Engineers (ASCE): Reston, VA, USA, 2020 ; pp. 96-103.

38. Zimmer, M. Molecular Mechanics Evaluation of the Proposed Mechanisms for the Degradation of Urea by Urease. J. Biomol. Struct. Dyn. 2000, 17, 787-797. [CrossRef]

39. Krajewska, B. Urease-aided calcium carbonate mineralization for engineering applications: A review. J. Adv. Res. 2018, 13, 59-67. [CrossRef] [PubMed]

40. Ibrahim, M.; Wijeratne, A.; Costa, M. Effect of different sources of urease on the treatment time and digestibility of urea-ammonia treated rice straw. Agric. Wastes 1985, 13, 197-205. [CrossRef]

41. Mateer, J.G.; Marshall, E.K. The Urease Content of Certain Beans, with Special Reference to the Jack Bean. J. Biol. Chem. 1916, 25, 297-305. [CrossRef]

42. Sumner, J.B. The isolation and crystallization of the enzyme urease. J. Biol. Chem. 1926, 69, 435-441. [CrossRef]

43. Blakeley, R.L.; Zerner, B. Jack bean urease: The first nickel enzyme. J. Mol. Catal. 1984, 23, 263-292. [CrossRef]

44. Almajed, A. Enzyme Induced Carbonate Precipitation (EICP) for Soil Improvement. Ph.D. Thesis, Arizona State University, Tempe, AZ, USA, 2017.

45. Khodadadi Tirkolaei, H.; Javadi, N.; Krishnan, V.; Hamdan, N.; Kavazanjian, E., Jr. Crude urease extract for biocementation. J. Mater. Civ. Eng. 2020, 32, 4020374. [CrossRef]

46. Kawasaki, D.R.A.S. Effective Use of Plant-Derived Urease in the Field of Geoenvironmental/Geotechnical Engineering. J. Civ. Environ. Eng. 2016, 6, 2. [CrossRef]

47. Javadi, N.; Khodadadi, H.; Hamdan, N.; Kavazanjian, E., Jr. EICP Treatment of Soil by Using Urease Enzyme Extracted from Watermelon Seeds. In IFCEE 2018; American Society of Civil Engineers (ASCE): Reston, VA, USA, 2018. [CrossRef]

48. Gao, Y.; He, J.; Tang, X.; Chu, J. Calcium carbonate precipitation catalyzed by soybean urease as an improvement method for fine-grained soil. Soils Found. 2019, 59, 1631-1637. [CrossRef]

49. Hoang, T.; Alleman, J.; Cetin, B.; Choi, S.-G. Engineering Properties of Biocementation Coarse- and Fine-Grained Sand Catalyzed by Bacterial Cells and Bacterial Enzyme. J. Mater. Civ. Eng. 2020, 32, 04020030. [CrossRef]

50. He, J.; Gao, Y.; Gu, Z.; Chu, J.; Wang, L. Characterization of Crude Bacterial Urease for CaCO3 Precipitation and Cementation of Silty Sand. J. Mater. Civ. Eng. 2020, 32, 04020071. [CrossRef]

51. Larsen, J.; Poulsen, M.; Lundgaard, T.; Agerbaek, M. Plugging of Fractures in Chalk Reservoirs by Enzyme-Induced Calcium Carbonate Precipitation. SPE Prod. Oper. 2008, 23, 478-483. [CrossRef]

52. Handley-Sidhu, S.; Sham, E.; Cuthbert, M.O.; Nougarol, S.; Mantle, M.; Johns, M.L.; Macaskie, L.E.; Renshaw, J.C. Kinetics of urease mediated calcite precipitation and permeability reduction of porous media evidenced by magnetic resonance imaging. Int. J. Environ. Sci. Technol. 2013, 10, 881-890. [CrossRef]

53. Arab, M.G.; Rohy, H.; Zeiada, W.; Almajed, A.; Omar, M. One-Phase EICP Biotreatment of Sand Exposed to Various Environmental Conditions. J. Mater. Civ. Eng. 2021, 33, 04020489. [CrossRef]

54. Javadi, N.; Tirkolaei, H.K.; Hamdan, N.; Kavazanjian, E. Longevity of Raw and Lyophilized Crude Urease Extracts. Sustain. Chem. 2021, 2, 18. [CrossRef]

55. Kutcherlapati, S.N.R.; Yeole, N.; Jana, T. Urease immobilized polymer hydrogel: Long-term stability and enhancement of enzymatic activity. J. Colloid Interface Sci. 2016, 463, 164-172. [CrossRef]

56. Almajed, A.; Tirkolaei, H.K.; Kavazanjian, E., Jr.; Hamdan, N. Enzyme Induced Biocementated Sand with High Strength at Low Carbonate Content. Sci. Rep. 2019, 9, 1-7. [CrossRef]

57. Lo, C.-Y.; Tirkolaei, H.K.; Hua, M.; De Rosa, I.; Carlson, L.; Kavazanjian, E.; He, X. Durable and ductile double-network material for dust control. Geoderma 2020, 361, 114090. [CrossRef]

58. Hamdan, N.M. Applications of Enzyme Induced Carbonate Precipitation (EICP) for Soil Improvement. Ph.D. Thesis, Arizona State University, Tempe, AZ, USA, 2015.

59. Kim, D.; Mahabadi, N.; Jang, J.; van Paassen, L.A. Assessing the Kinetics and Pore-Scale Characteristics of Biological Calcium Carbonate Precipitation in Porous Media using a Microfluidic Chip Experiment. Water Resour. Res. 2020, 56, e2019WR025420. [CrossRef]

60. Neupane, D.; Yasuhara, H.; Kinoshita, N.; Unno, T. Applicability of Enzymatic Calcium Carbonate Precipitation as a SoilStrengthening Technique. J. Geotech. Geoenviron. Eng. 2013, 139, 2201-2211. [CrossRef] 
61. Almajed, A.; Tirkolaei, H.K.; Kavazanjian, E., Jr. Baseline Investigation on Enzyme-Induced Calcium Carbonate Precipitation. J. Geotech. Geoenviron. Eng. 2018, 144, 04018081. [CrossRef]

62. Carmona, J.P.; Oliveira, P.V.; Lemos, L. Biostabilization of a Sandy Soil Using Enzymatic Calcium Carbonate Precipitation. Procedia Eng. 2016, 143, 1301-1308. [CrossRef]

63. Ahenkorah, I.; Rahman, M.; Karim, R.; Teasdale, P.R. Optimization of Enzyme Induced Carbonate Precipitation (EICP) as a Ground Improvement Technique. In Geo-Congress 2020; American Society of Civil Engineers (ASCE): Reston, VA, USA, 2020; pp. 552-561.

64. Johnson, K.A.; Goody, R.S. The Original Michaelis Constant: Translation of the 1913 Michaelis-Menten Paper. Biochemistry 2011, 50, 8264-8269. [CrossRef]

65. Leszko, M.; Zaborska, W.; Krajewska, B. Urease-catalyzed hydrolysis of urea differential vs. integration kinetic methods. Bull. Pol. Acad. Sci. Chem. 1997, 45, 129-138.

66. Laidler, K.J.; Hoare, J.P. The Molecular Kinetics of the Urea-Urease System. III. Heats and Entropies of Complex Formation and Reaction1. J. Am. Chem. Soc. 1950, 72, 2489-2494. [CrossRef]

67. Ahenkorah, I.; Rahman, M.; Karim, R.; Beecham, S.; Saint, C. A Review of Enzyme Induced Carbonate Precipitation (EICP): The Role of Enzyme Kinetics. Sustain. Chem. 2021, 2, 7. [CrossRef]

68. Miftah, A.; Tirkolaei, H.K.; Bilsel, H. Biocementation of Calcareous Beach Sand Using Enzymatic Calcium Carbonate Precipitation. Crystals 2020, 10, 888. [CrossRef]

69. Nemati, M.; Greene, E.A.; Voordouw, G. Permeability profile modification using bacterially formed calcium carbonate: Comparison with enzymic option. Process. Biochem. 2005, 40,925-933. [CrossRef]

70. Chandra, A.; Ravi, K. Application of Enzyme-Induced Carbonate Precipitation (EICP) to Improve the Shear Strength of Different Type of Soils. In Lecture Notes in Civil Engineering; Springer: Singapore, 2020; pp. 617-632.

71. Ahenkorah, I.; Rahman, M.; Karim, R.; Beecham, S. Optimisation of chemical constituents on enzyme-induced carbonate precipitation in test-tube and soil. Geotech. Res. 2021, 8, 66-84. [CrossRef]

72. Krajewska, B. A combined temperature-pH study of urease kinetics. Assigning pKa values to ionizable groups of the active site involved in the catalytic reaction. J. Mol. Catal. B Enzym. 2016, 124, 70-76. [CrossRef]

73. Goličnik, M. The integrated Michaelis-Menten rate equation: Déjà vu or vu jàdé? J. Enzyme. Inhib. Med. Chem. 2013, 28, 879-893. [CrossRef]

74. Zhao, Z.; Hamdan, N.; Shen, L.; Nan, H.; Almajed, A.; Kavazanjian, E.; He, X. Biomimetic Hydrogel Composites for Soil Stabilization and Contaminant Mitigation. Environ. Sci. Technol. 2016, 50, 12401-12410. [CrossRef]

75. Rebata-Landa, V. Microbial Activity in Sediments: Effects on Soil Behavior. Ph.D. Thesis, Georgia Institution of Technology, Atlanta, GA, USA, 2007.

76. Jacob, D.J. Introduction to Atmospheric Chemistry; Princeton University Press: Princeton, NJ, USA, 1999.

77. Chouhan, S.; Gayathri, R. Extraction and partial purification of urease enzyme from Jack fruit. Int. J. Res. Pharm. Sci. 2018, 9, 438-441.

78. Kavazanjian, E., Jr.; Almajed, A.; Hamdan, N. Bio-Inspired Soil Improvement Using EICP Soil Columns and Soil Nails. In Grouting 2017; American Society of Civil Engineers (ASCE): Reston, VA, USA, 2017.

79. Martin, K.K.; Tirkolaei, H.K.; Kavazanjian, E., Jr. Mid-scale biocemented soil columns via enzyme-induced carbonate precipitation (EICP). Soils Found. 2021. [CrossRef]

80. Choi, S.-G.; Chang, I.; Lee, M.; Lee, J.-H.; Han, J.-T.; Kwon, T.-H. Review on geotechnical engineering properties of sands treated by microbially induced calcium carbonate precipitation (MICP) and biopolymers. Constr. Build. Mater. 2020, $246,118415$. [CrossRef]

81. Pasillas, J.N.; Khodadadi, H.; Martin, K.; Bandini, P.; Newtson, C.M.; Kavazanjian, E. Viscosity-Enhanced EICP Treatment of Soil. In IFCEE 2018; American Society of Civil Engineers (ASCE): Reston, VA, USA, 2018. [CrossRef]

82. Refaei, M.; Arab, M.G.; Omar, M. Sandy Soil Improvement through Biopolymer Assisted EICP. In Geo-Congress 2020; American Society of Civil Engineers (ASCE): Reston, VA, USA, 2020. [CrossRef]

83. Pandey, G. Feasibility Study of Water Based/Polymer Modified EICP for Soil Improvement Involving Recycled Glass Aggregate. Master's Thesis, University of Akron, Akron, OH, USA, 2018.

84. Miao, L.; Wu, L.; Sun, X. Enzyme-catalysed mineralisation experiment study to solidify desert sands. Sci. Rep. 2020, 10, 1-12. [CrossRef]

85. Cho, G.-C.; Dodds, J.; Santamarina, J.C. Particle Shape Effects on Packing Density, Stiffness, and Strength: Natural and Crushed Sands. J. Geotech. Geoenviron. Eng. 2006, 132, 591-602. [CrossRef]

86. Ivanov, V.; Chu, J.; Stabnikov, V.; Li, B. Strengthening of Soft Marine Clay Using Bioencapsulation. Mar. Georesources Geotechnol. 2015, 33, 320-324. [CrossRef]

87. Zhao, Q.; Li, L.; Li, C.; Li, M.; Amini, F.; Zhang, H. Factors Affecting Improvement of Engineering Properties of MICP-Treated Soil Catalyzed by Bacteria and Urease. J. Mater. Civ. Eng. 2014, 26, 04014094. [CrossRef]

88. Van Paassen, L.A.; Pieron, M.; Mulder, A.; Ngan-Tillard, D.J.M.; Van Der Linden, T.J.M. Strength and deformation of biologically cemented sandstone. In Proceedings of the ISRM Regional conference EUROCK, Dubrovnik, Croatia, 29-31 October 2009; pp. $405-410$. 
89. Al Qabany, A.; Soga, K. Effect of chemical treatment used in MICP on engineering properties of cemented soils. Géotechnique 2013, 63, 331. [CrossRef]

90. Cheng, L.; Cord-Ruwisch, R. Selective enrichment and production of highly urease active bacteria by non-sterile (open) chemostat culture. J. Ind. Microbiol. Biotechnol. 2013, 40, 1095-1104. [CrossRef]

91. Rohy, H.; Arab, M.; Zeiada, W.; Omar, M.; Almajed, A.; Tahmaz, A. One Phase Soil Bio-Cementation with EICP-Soil Mixing In Proceedings of the 4th World Congress on Civil, Structural, and Environmental Engineering, Rome, Italy, 7-9 April 2019.

92. Ahenkorah, I.; Rahman, M.M.; Karim, M.R.; Teasdale, P.R. A comparison of mechanical responses for microbial- and enzymeinduced cemented sand. Géotech. Lett. 2020, 10, 559-567. [CrossRef]

93. Neupane, D.; Yasuhara, H.; Kinoshita, N.; Ando, Y. Distribution of mineralized carbonate and its quantification method in enzyme mediated calcite precipitation technique. Soils Found. 2015, 55, 447-457. [CrossRef]

94. Beser, G.D. Ureolysis Induced Mineral Precipitation Material Properties. Master's Thesis, Montana State University, Bozeman, MT, USA, 2018.

95. Lee, S.; Kim, J. An Experimental Study on Enzymatic-Induced Carbonate Precipitation Using Yellow Soybeans for Soil Stabilization. KSCE J. Civ. Eng. 2020, 24, 2026-2037. [CrossRef]

96. Park, S.-S.; Choi, S.-G.; Nam, I.-H. Effect of Plant-Induced Calcite Precipitation on the Strength of Sand. J. Mater. Civ. Eng. 2014, 26, 06014017. [CrossRef]

97. Putra, H.; Yasuhara, H.; Kinoshita, N.; Neupane, D.; Lu, C.-W. Effect of Magnesium as Substitute Material in Enzyme-Mediated Calcite Precipitation for Soil-Improvement Technique. Front. Bioeng. Biotechnol. 2016, 4, 37. [CrossRef] [PubMed]

98. Putra, H.; Yasuhara, H.; Kinoshita, N.; Neupane, D. Optimization of Calcite Precipitation as a Soil Improvement Technique. In Proceedings of the 2nd Makassar International Conference in Civil Engineering, Makassar, Indonesia, 11-12 August 2015; pp. 9-14.

99. Putra, H.; Yasuhara, H.; Kinoshita, N. Optimum condition for the application of enzyme-mediated calcite precipitation technique as soil improvement method. Int. J. Adv. Sci. Eng. Inf. Technol. 2017, 7, 2145-2151. [CrossRef]

100. Almajed, A.; Khodadadi, H.; Kavazanjian, E., Jr. Sisal Fiber Reinforcement of EICP-Treated Soil. In IFCEE 2018; American Society of Civil Engineers (ASCE): Reston, VA, USA, 2018. [CrossRef]

101. Song, J.Y.; Ha, S.J.; Jang, J.W.; Yun, T.S. Analysis of Improved Shear Stiffness and Strength for Sandy Soils Treated by EICP. J. Korean Geotech. Soc. 2020, 36, 17-28.

102. Aishwarya, A.; Christy, A. Bio cemented Sands. In Proceedings of the Indian Geotechnical Conference 2017 GeoNEst, Guwahati, India, 14-16 December 2017; pp. 14-17.

103. Putra, H.; Yasuhara, H.; Kinoshita, N.; Sudibyo, T. Improving Shear Strength Parameters of Sandy Soil using Enzyme-Mediated Calcite Precipitation Technique. Civ. Eng. Dimens. 2018, 20, 91-95. [CrossRef]

104. Nafisi, A.; Montoya, B.M.; Evans, T.M. Shear Strength Envelopes of Biocemented Sands with Varying Particle Size and Cementation Level. J. Geotech. Geoenviron. Eng. 2020, 146, 04020002. [CrossRef]

105. Obeidy, C.S.; Savavisadeh, S.; Montoya, B. Assessing the Mechanical Stability of Coal Ash via Enzyme Induced Calcium Carbonate Precipitation. In Proceedings of the Tampa, Florida, USA, 22-25 October 2017.

106. Xiao, P.; Liu, H.; Stuedlein, A.; Evans, T.M.; Xiao, Y. Effect of relative density and biocementation on cyclic response of calcareous sand. Can. Geotech. J. 2019, 56, 1849-1862. [CrossRef]

107. Mehdizadeh, A.; Disfani, M.M.; Evans, R.; Arulrajah, A.; Ong, D.E.L. Discussion of “development of an internal camera-based volume determination system for triaxial testing" by se Salazar, a. Barnes and Ra Coffman. The technical note was published in geotechnical testing journal, vol. 38, no. 4, 2015. Geotech. Test. J. 2016, 39, 165-168. [CrossRef]

108. Xiao, Y.; Stuedlein, A.W.; Ran, J.; Evans, T.M.; Cheng, L.; Liu, H.; Van Paassen, L.A.; Chu, J. Effect of Particle Shape on Strength and Stiffness of Biocemented Glass Beads. J. Geotech. Geoenviron. Eng. 2019, 145, 06019016. [CrossRef]

109. Ismail, M.A.; Joer, H.A.; Randolph, M.F.; Meritt, A. Cementation of porous materials using calcite. Geotechnique 2002, 52, 313-324. [CrossRef]

110. Almajed, A.; Abbas, H.; Arab, M.; Alsabhan, A.; Hamid, W.; Al-Salloum, Y. Enzyme-Induced Carbonate Precipitation (EICP)Based methods for ecofriendly stabilization of different types of natural sands. J. Clean. Prod. 2020, 274, 122627. [CrossRef]

111. Krishnan, V.; Khodadadi, H.T.; Martin, K.; Hamdan, N.M.; Kavazanjian, E.; Van Paassen, L.A. Variation in strength of EICP treated "standard" sand. In Proceedings of the B2G Atlanta 2018, Atlanta, GA, USA, 10-13 September 2019.

112. Krishnan, V.; Tirkolaei, H.K.; Martin, K.; Hamdan, N.; van Paassen, L.A.; Kavazanjian, E. Variability in the Unconfined Compressive Strength of EICP-Treated "Standard" Sand. J. Geotech. Geoenviron. Eng. 2021, 147, 06021001. [CrossRef]

113. Oliveira, P.V.; Freitas, L.D.; Carmona, J.P.S.F. Effect of Soil Type on the Enzymatic Calcium Carbonate Precipitation Process Used for Soil Improvement. J. Mater. Civ. Eng. 2017, 29, 04016263. [CrossRef]

114. Zango, M.U.; Kassim, K.A.; Muhammed, A.S.; Ahmad, K.; Makinda, J. Effect of Biocementation via Enzymatic Induced Calcium Carbonate Precipitation (EICP) on the Shear Strength of Compacted Clay Liner. IOP Conf. Ser. Mater. Sci. Eng. 2021, 1153, 012008. [CrossRef]

115. Zehner, J.; Røyne, A.; Sikorski, P. A sample cell for the study of enzyme-induced carbonate precipitation at the grain-scale and its implications for biocementation. Sci. Rep. 2021, 11, 1-10. [CrossRef]

116. Chahal, N.; Rajor, A.; Siddique, R. Calcium carbonate precipitation by different bacterial strains. Afr. J. Biotechnol. 2011, 10, 8359-8372. 
117. Dupraz, C.; Visscher, P.T.; Baumgartner, L.K.; Reid, R.P. Microbe-mineral interactions: Early carbonate precipitation in a hypersaline lake (Eleuthera Island, Bahamas). Sedimentology 2004, 51, 745-765. [CrossRef]

118. Martin, K.; Tirkolaei, H.K.; Kavazanjian, E. Enhancing the strength of granular material with a modified enzyme-induced carbonate precipitation (EICP) treatment solution. Constr. Build. Mater. 2021, 271, 121529. [CrossRef]

119. Nafisi, A.; Safavizadeh, S.; Montoya, B.M. Influence of Microbe and Enzyme-Induced Treatments on Cemented Sand Shear Response. J. Geotech. Geoenviron. Eng. 2019, 145, 06019008. [CrossRef]

120. Kiasari, M.A.; Pakbaz, M.S.; Ghezelbash, G.R. Comparison of Effects of Different Nutrients on Stimulating Indigenous Soil Bacteria for Biocementation. J. Mater. Civ. Eng. 2019, 31, 04019067. [CrossRef]

121. Cui, M.-J.; Lai, H.-J.; Hoang, T.; Chu, J. One-phase-low-pH enzyme induced carbonate precipitation (EICP) method for soil improvement. Acta Geotech. 2021, 16, 481-489. [CrossRef]

122. Cui, M.J.; Lai, H.J.; Hoang, T.; Chu, J. Modified one-phase-low-pH method for bacteria or enzyme-induced carbonate precipitation for soil improvement. Acta Geotech. 2011, 1-11. [CrossRef]

123. Wen, K.; Li, Y.; Li, L.; Amini, F. Development of a Multiple Treatment Laboratory Method to Enhance Microbial-Induced Soil Stabilization. In IFCEE 2018; American Society of Civil Engineers: Reston, VA, USA, 2018; pp. 12-18. [CrossRef]

124. Nething, C.; Smirnova, M.; Gröning, J.A.; Haase, W.; Stolz, A.; Sobek, W. A method for 3D printing bio-cemented spatial structures using sand and urease active calcium carbonate powder. Mater. Des. 2020, 195, 109032. [CrossRef]

125. Omoregie, A.I.; Palombo, E.A.; Ong, D.E.; Nissom, P.M. A feasible scale-up production of Sporosarcina pasteurii using custombuilt stirred tank reactor for in-situ soil biocementation. Biocatal. Agric. Biotechnol. 2020, 24, 101544. [CrossRef]

126. Martin, K.K.; Khodadadi, T.H.; Chester, M.; Kavazanjian, E., Jr. Hotspot Life Cycle Assessment for Environmental Impacts of EICP for Ground Improvement. In Geo-Congress 2020; American Society of Civil Engineers: Reston, VA, USA, 2020. [CrossRef]

127. Putra, H.; Yasuhara, H.; Kinoshita, N.; Hirata, A. Optimization of Enzyme-Mediated Calcite Precipitation as a Soil-Improvement Technique: The Effect of Aragonite and Gypsum on the Mechanical Properties of Treated Sand. Crystals 2017, 7, 59. [CrossRef]

128. Farrell, H., Jr.; Kumosinski, T.; Malin, E.; Brown, E. The caseins of milk as calcium-binding proteins. Biochemistry 1988, 23, 5912-5923.

129. Song, J.Y.; Sim, Y.; Yeom, S.; Jang, J.; Yun, T.S. Stiffness loss in enzyme-induced carbonate precipitated sand with stress scenarios. Geomech. Eng. 2020, 20, 165-174. [CrossRef]

130. Mehdizadeh, A.; Disfani, M.M.; Evans, R.; Arulrajah, A.; Ong, D.E.L. Mechanical Consequences of Suffusion on Undrained Behaviour of a Gap-Graded Cohesionless Soil-An Experimental Approach. Geotech. Test. J. 2017, 40, 1026-1042. [CrossRef]

131. Pratama, G.B.S.; Yasuhara, H.; Kinoshita, N.; Putra, H. Application of soybean powder as urease enzyme replacement on EICP method for soil improvement technique. IOP Conf. Ser. Earth Environ. Sci. 2021, 622, 012035. [CrossRef]

132. Hamdan, N.; Zhao, Z.; Mujica, M.; Kavazanjian, E.; He, X. Hydrogel-Assisted Enzyme-Induced Carbonate Mineral Precipitation. J. Mater. Civ. Eng. 2016, 28, 04016089. [CrossRef]

133. Cuccurullo, A.; Gallipoli, D.; Bruno, A.W.; Augarde, C.; Hughes, P.; La Borderie, C. Soil Stabilization against Water Erosion via Calcite Precipitation by Plant-Derived Urease. In Proceedings of FORM 2021; Springer: Singapore, 2019; pp. 753-762. 